Universidade de Brasília

Instituto de Ciências Humanas

Departamento de Geografia

Programa de Pós-Graduação em Geografia

UNIVERSIDADE DE BRASILIA

PÓS-GRADUAÇÃO EM GEOGRAFIA

\title{
DISTRIBUIÇÃO ESPACIAL DA HEPATITE A NA REGIÃO DE SOBRADINHO/DF ENTRE 2007 E 2015
}

Alexandre Sauma da Silva

Dissertação de Mestrado

Brasília-DF: Dezembro/2016 
Universidade de Brasília

Instituto de Ciências Humanas

Departamento de Geografia

Programa de Pós-Graduação em Geografia

UNIVERSIDADE DE BRASILIA

PÓS-GRADUAÇÃO EM GEOGRAFIA

DISTRIBUIÇÃO ESPACIAL DA HEPATITE A NA REGIÃO DE

SOBRADINHO/DF ENTRE 2007 E 2015

Alexandre Sauma da Silva

Orientadora: Profa. Dra. Helen da Costa Gurgel

Coorientador: Prof. Dr. Walter Massa Ramalho

Dissertação de Mestrado

Brasília-DF: Dezembro/2016 
Universidade de Brasília

Instituto de Ciências Humanas

Departamento de Geografia

Programa de Pós-Graduação em Geografia

UNIVERSIDADE DE BRASILIA

PÓS-GRADUAÇÃO EM GEOGRAFIA

\section{DISTRIBUIÇÃO ESPACIAL DA HEPATITE A NA REGIÃO DE SOBRADINHO/DF ENTRE 2007 E 2015}

\section{Alexandre Sauma da Silva}

Dissertação de Mestrado submetida ao Departamento de Geografia da Universidade de Brasília, como parte dos requisitos necessários para a obtenção do Grau de Mestre em Geografia, área de concentração Gestão Ambiental e Territorial, opção Acadêmica.

Aprovado por:

Dra. Helen da Costa Gurgel (Doutora), UnB

(Orientadora)

Dra. Eucilene Alves Santana (Doutora), Ministério da Saúde

(Examinadora Externa)

Dr. Wildo Navegantes de Araújo (Doutor), UnB

(Examinador Externo)

Dr. Valdir Adilson Steinke (Doutor), UnB

(Membro Suplente)

Brasília-DF, 15 de dezembro de 2016 
Universidade de Brasília

Instituto de Ciências Humanas

Departamento de Geografia

Programa de Pós-Graduação em Geografia

\section{SILVA, ALEXANDRE SAUMA DA}

Distribuição espacial da Hepatite A na Região de Sobradinho/DF entre 2007 e 2015, 99 p., 297 mm, (UnB-GEA, Mestre, Gestão Territorial e Ambiental, 2016).

Dissertação de Mestrado - Universidade de Brasília. Departamento de Geografia.

1. Hepatite A

3. Doenças hídricas

4. Modelo Digital de Terreno
2. Epidemiologia

3. Setores censitários

É concedida à Universidade de Brasília permissão para reproduzir cópias desta dissertação e emprestar ou vender tais cópias somente para propósitos acadêmicos e científicos. $\mathrm{O}$ autor reserva outros direitos de publicação e nenhuma parte desta dissertação de mestrado pode ser reproduzida sem a autorização por escrito do autor. 


\section{AGRADECIMENTOS}

À Deus, pelo dom da vida.

Aos meus pais José e Maria, que me deram condições para que eu pudesse chegar até aqui.

À minha esposa Renata, pela compreensão nos momentos de ausência e pelo apoio durante todo esse período de estudo.

Às minhas irmãs Jaqueline e Cristiane.

À Dra. Helen da Costa Gurgel, por ter aceitado o meu projeto, pelas orientações, pelos conhecimentos e pela confiança depositada em mim, sempre me incentivando a ir além.

Ao Dr. Walter Massa Ramalho pela coorientação, disposição em ajudar e pelo incentivo durante a pesquisa.

À Dra. Eucilene Alves Santana e ao Dr. Wildo Navegantes de Araújo, presentes à banca de qualificação, pelo aceite do convite e pelas contribuições para a melhoria da pesquisa.

À equipe do LAGAS: Dra. Anne-Elisabeth Lagues, Ana Júlia, Leandro, Nayara, Daniel, Yata, Rogério e Bruna.

A toda equipe da DIVEP, sempre solícitos e dispostos a colaborar com a pesquisa, e, em especial, Rosângela, Adelson, Cleidiane e Rosamaria, pela paciência e disponibilidade nas minhas solicitações.

À Ana Karla do HRS, por toda a ajuda empenhada e pelos conselhos, sempre solícita aos meus questionamentos.

Ao Janduhy Pereira dos Santos, pela amizade, conselhos e auxílio, sempre disposto a me ajudar.

Ao Roberto Souza Borges, pela amizade e ajuda na coleta dos dados.

A todos da DIGEO, que direta ou indiretamente contribuíram com este trabalho. 


\section{RESUMO}

A Hepatite A é uma doença hídrica e, de modo geral, transmitida pela via fecal-oral por meio da água e de alimentos contaminados. Esse agravo é relacionado a regiões economicamente menos desenvolvidas, onde a prevalência da doença é alta em ambientes sem acesso adequado aos serviços de água e esgoto. No Distrito Federal a Hepatite A apresenta média endemicidade. O objetivo deste trabalho foi realizar um estudo ecológico sobre o perfil epidemiológico dos casos notificados de HVA na região de Sobradinho/DF entre os anos de 2007 e 2015 a partir de um foco epidemiológico, sob a ótica de fatores ambientais, econômicos e sociais. Esses parâmetros foram importantes para a realização de um diagnóstico local. Foram identificados e georreferenciados 50 casos positivos e destes, 48 pertenciam à área de estudo. O padrão espacial do agravo na região indicou que a maioria dos casos ocorreram em ambientes urbanizados, classificados em áreas urbanas e ou periurbanas e $39,54 \%$ dos notificados pertenciam à faixa etária entre 6 e 10 anos. Em relação aos aspectos ambientais, a maior parte das notificações vincularam-se à altitude entre 1051 e 1100 metros, altimetria média quando comparada a toda a área de estudo. A utilização do mapa de densidade Kernel mostrou três áreas de concentração dos casos, uma em Sobradinho na região mais próxima ao Ribeirão Sobradinho, a segunda entre Sobradinho II e condomínios próximos e a terceira na região da Vila Rabelo, local conhecido por suas fragilidades ambientais. Os resultados gerados pela análise socioeconômica foram baseados nos setores censitários do Censo do IBGE. Quase metades dos notificados residem nos setores censitários com a maior concentração de população e a variável que melhor identificou a diferença entre os setores censitários notificados com casos de Hepatite A daqueles não notificados foi a renda. Por fim, o estudo confirmou a importância dos fatores socioeconômicos são para caracterização das áreas de notificação do agravo.

Palavras-chave: Hepatite A. Epidemiologia. Análise Ambiental. Setores Censitários. 


\begin{abstract}
Hepatitis $\mathrm{A}$ is a waterborne disease transmitted by the fecal-oral route through water and contaminated food. This is related to economically less developed regions where the prevalence of the disease is high in environments without adequate access to water and sewage services. In Distrito Federal Hepatitis A presents medium endemicity. The purpuse of this study was to carry out an ecological study on the epidemiological profile of the reported cases of HVA in the Sobradinho / DF region between 2007 and 2015, based on epidemiological focus from environmental, economic and social factors. These parameters were important for conducting a local diagnosis. 50 positive cases were identified and georeferenced, which 48 belonged to the study area. The spatial pattern of the disease in the region indicated the majority of cases occurred in urbanized environments, classified in urban and peri-urban areas, and 39.54\% of those reported belonged to the age group between 6 and 10 years. Regarding the environmental aspects, most of the notifications were related to the altitude between 1051 and 1100 meters, average altimetry when compared to the entire study area. The use of the Kernel density map showed three areas of concentration of cases: Sobradinho in the region closest to Ribeirão Sobradinho, Sobradinho II and nearby less developed places and the region of Vila Rabelo a place known for its environmental fragilities. The results generated by the socioeconomic analysis were based on the census tracts of the IBGE Census. Almost half of those reported reside in the census tracts with the highest concentration of population and the variable that best identified the difference between census tracts reported with cases of Hepatitis A of those not reported was income. The study confirmed the importance of socioeconomic factors to characterize the areas of notification of the grievance.
\end{abstract}

Key words: Hepatitis A. Epidemiology. Environmental analysis. Census Sectors. 


\section{LISTA DE ILUSTRAÇÕES}

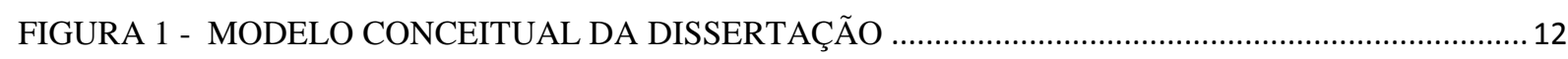

FIGURA 2 - RELAÇÃO DE BOMBAS D'ÁGUA E O NÚMERO DE MORTES EM LONDRES.....................2 20

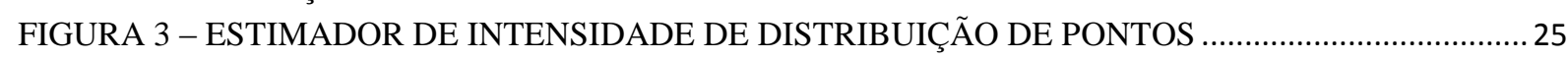

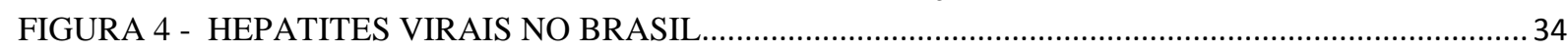

FIGURA 5 - VILA RABELO PRÓXIMO A ÁREAS DE RISCO ……............................................................... 44

FIGURA 6 - DEPÓSITO DE RESÍDUOS PRÓXIMO À MATA DE GALERIA DO RIBEIRÃO

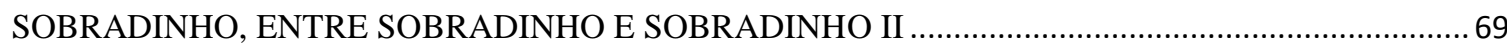

GRÁFICO 1 - REGIME PLUVIOMÉTRICO EM 2007................................................................................ 70

GRÁFICO 2 - REGIME PLUVIOMÉTRICO EM 2008

GRÁFICO 3 - REGIME PLUVIOMÉTRICO EM 2009.............................................................................. 72

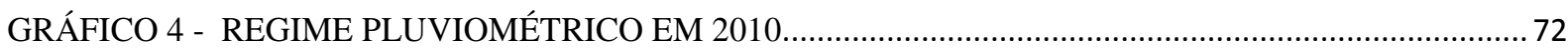

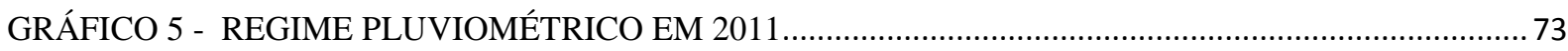

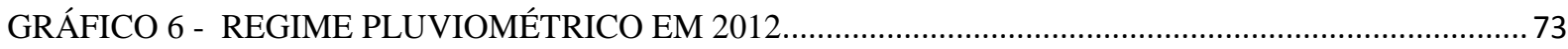

GRÁFICO 7 - REGIME PLUVIOMÉTRICO EM 2013 ………..................................................................... 74

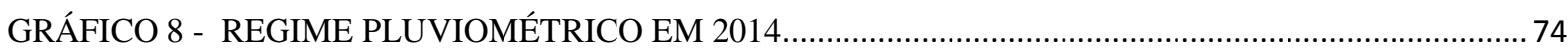

GRÁFICO 9 - REGIME PLUVIOMÉTRICO EM 2015................................................................................... 75

GRÁFICO 10 - CASOS NOTIFICADOS, POR ANO E A PLUVIOMETRIA MENSAL. ....................................76

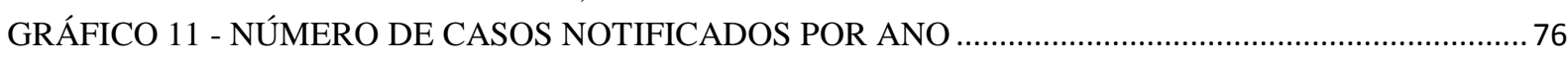

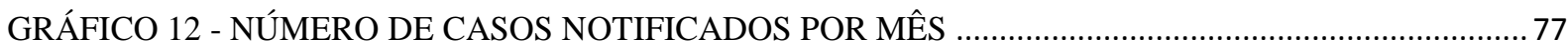

GRÁFICO 13 - DISTRIBUIÇÃO DOS CASOS POR SEMANA EPIDEMIOLÓGICA...................................... 77

GRÁFICO 14 - DISTRIBUIÇÃO DA PAISAGEM EM SOBRADINHO. ……………………………………....... 79

MAPA 1 - ÁREA DE ESTUDO E A HIDROGRAFIA LOCAL. ………………………………………….......14

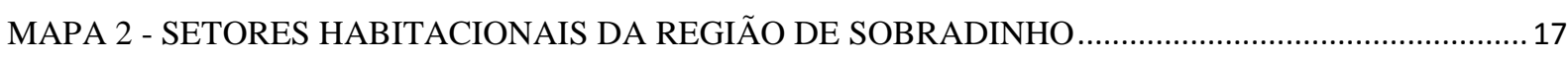

MAPA 3 - REGIÕES DE SAÚDE DO DF .............................................................................................. 26

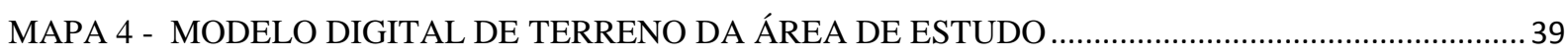

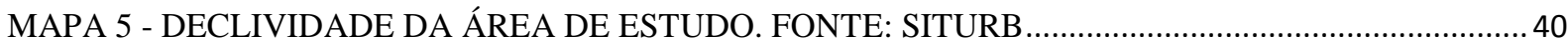

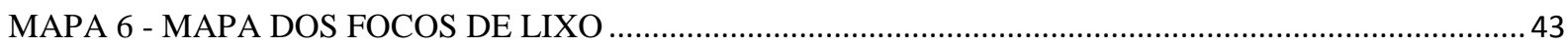

MAPA 7 - ESPACIALIZAÇÃO DOS CASOS CONFIRMADOS DE HEPATITE A NA REGIÃO DE

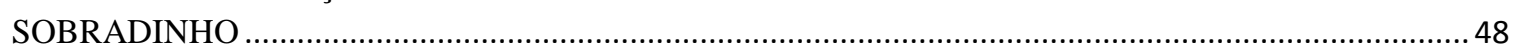

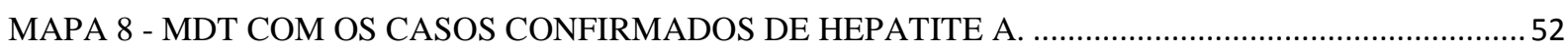

MAPA 9 - DECLIVIDADE E OS CASOS CONFIRMADOS DE HEPATITE A …………………………........53

MAPA 10 - ESPACIALIZAÇÃO TEMPORAL DOS CASOS DE HEPATITE A NA RA DE SOBRADINHO

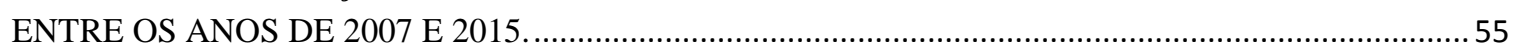

MAPA 11 - CORPOS HÍDRICOS E OS CASOS DE HEPATITE A NA RA DE SOBRADINHO ENTRE OS

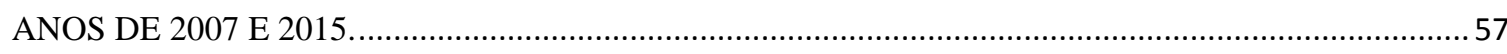

MAPA 12 - DETALHAMENTO DA ESPACIALIZAÇÃO TEMPORAL DOS CASOS DE HEPATITE A E O

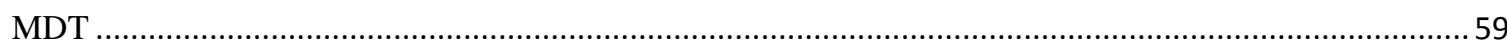

MAPA 13 - DETALHAMENTO DA ESPACIALIZAÇÃO TEMPORAL DOS CASOS DE HEPATITE A E A

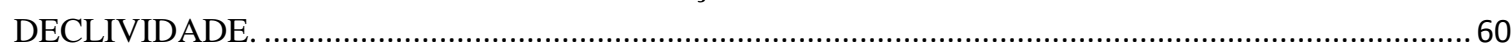

MAPA 14 - DENSIDADE KERNEL PARA OS CASOS CONFIRMADOS DE HEPATITE A ….......................62

MAPA 15 - MAPA DE KERNEL JUNTO AOS SETORES CENSITÁRIOS ………..........................................64

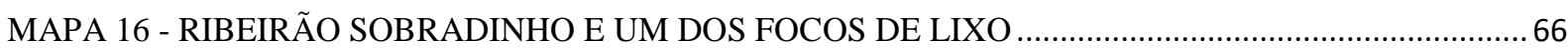

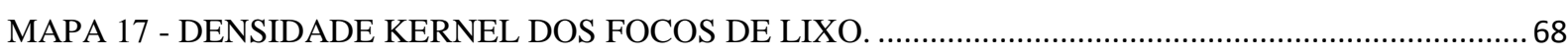

MAPA 18 - MAPA DA CLASSIFICAÇÃO DO USO DO SOLO EM 2007................................................... 78 
MAPA 19 - MAPA DOS SETORES CENSITÁRIOS E A CONFIRMAÇÃO DE HEPATITE A ……………...... 81

MAPA 20 - MAPA DOS SETORES CENSITÁRIOS PELA POPULAÇÃO TOTAL ………………………...... 83 


\section{LISTA DE TABELAS}

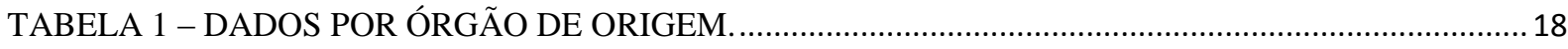

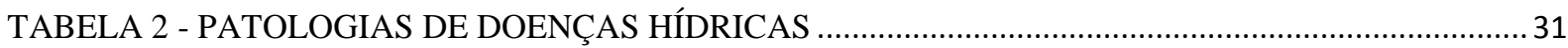

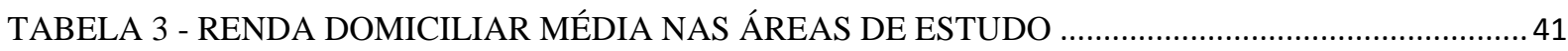

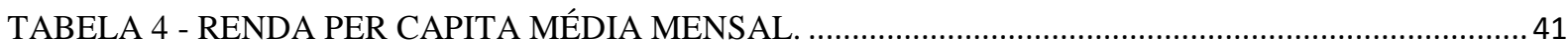

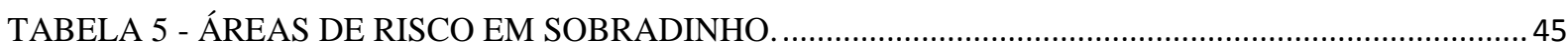

TABELA 6 - DISTRIBUIÇÃO DOS CASOS DE HEPATITE POR IDADE ………………………………........ 50

TABELA 7 - NOTIFICAÇÃO DOS CASOS DE HEPATITE POR INSTITUCIONALIZAÇÃO. ......................51

TABELA 8 - CASOS DE HEPATITE POR FONTE

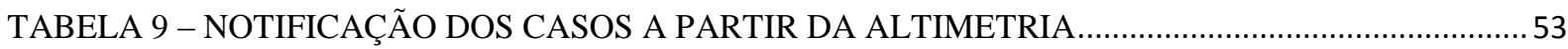

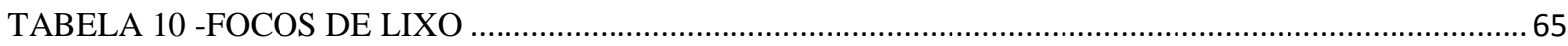

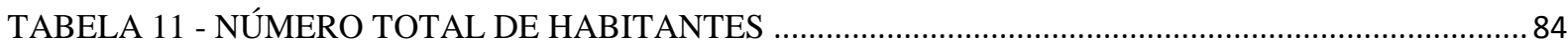

TABELA 12 - ESCOLARIDADE POR SETOR CENSITÁRIO NOTIFICADOS E NÃO NOTIFICADOS......85

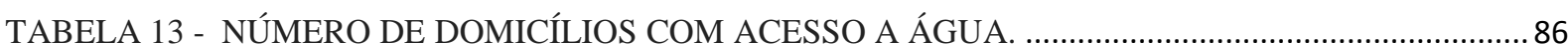

TABELA 14 - NÚMERO DE DOMICÍLIOS COM ACESSO A ENERGIA ELÉTRICA. ...................................87

TABELA 15 - NÚMERO DE DOMICÍLIOS COM ACESSO A COLETA DE LIXO ………........................... 88

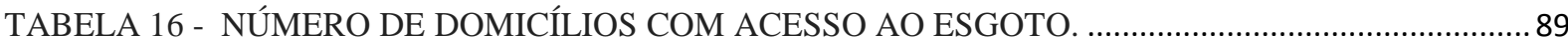

TABELA 17 - NÚMERO DE DOMICÍLIOS POR RENDIMENTO MENSAL..................................................90 


\section{SUMÁRIO}

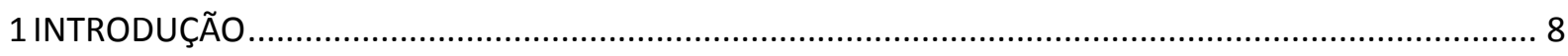

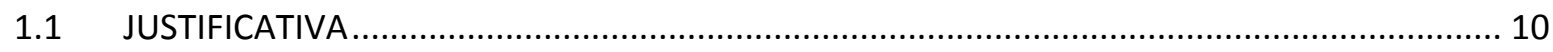

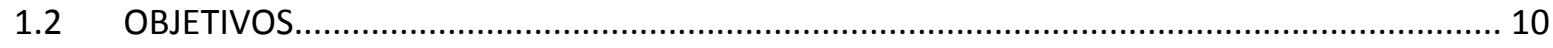

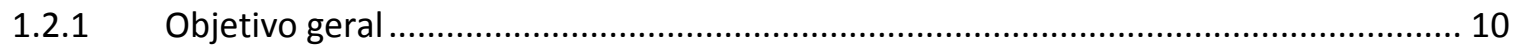

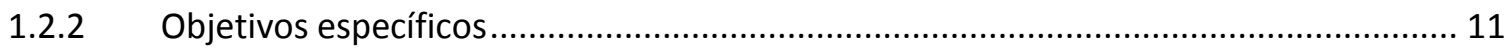

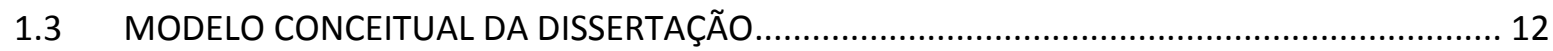

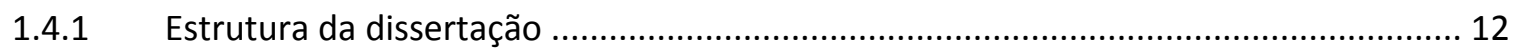

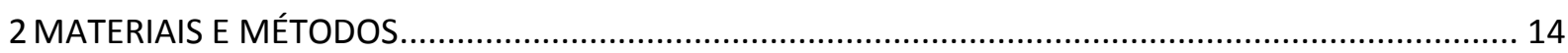

2.1 DEFINIÇÃO E CONTEXTUALIZAÇÃO DA ÁREA DE ESTUDO …............................................... 14

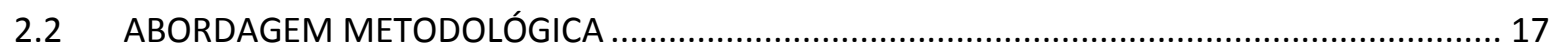

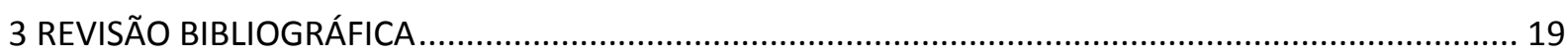

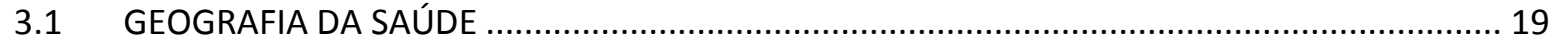

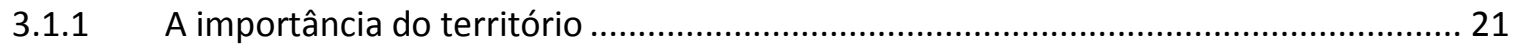

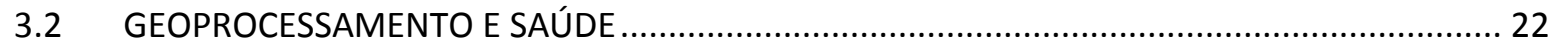

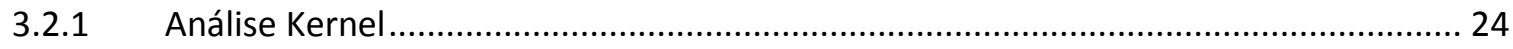

3.3 O USO DOS SERVIÇOS DE SAÚDE

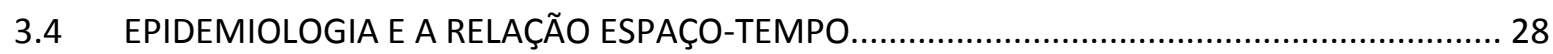

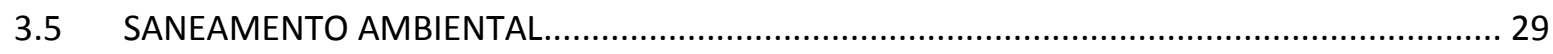

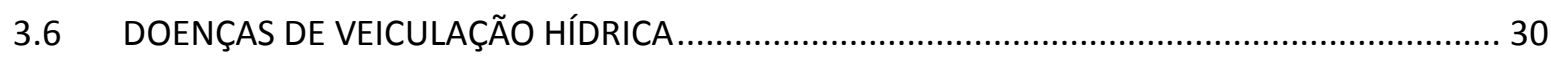

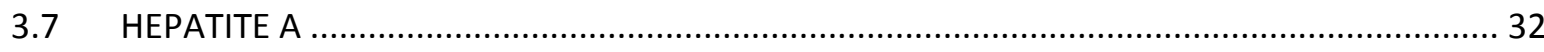

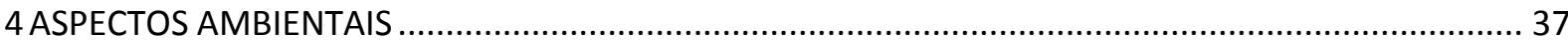

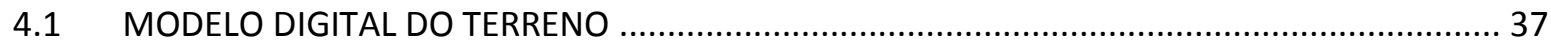

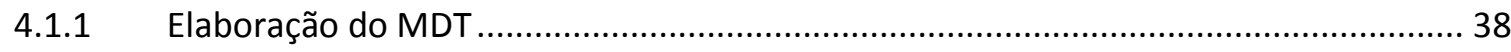

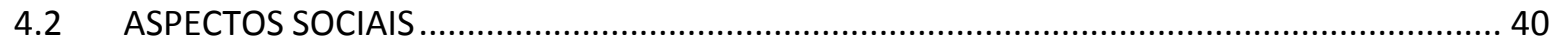

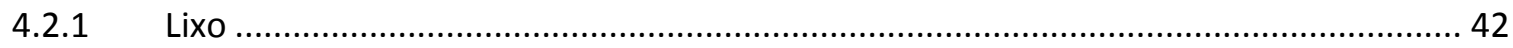

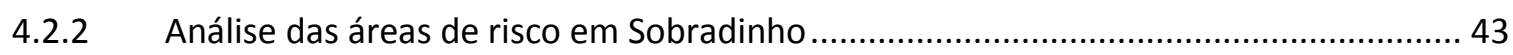

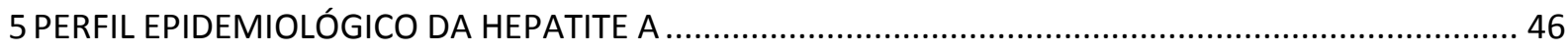

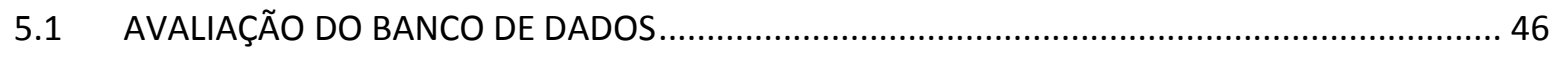

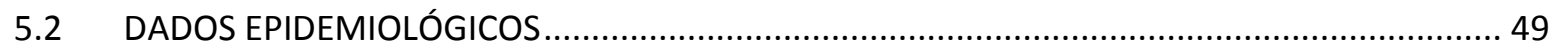




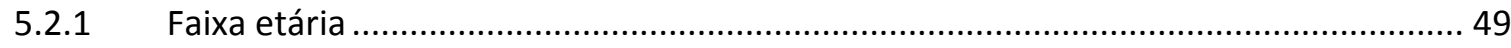

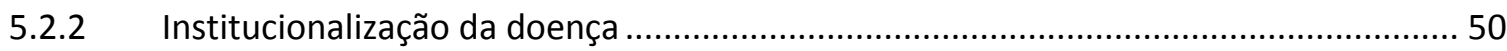

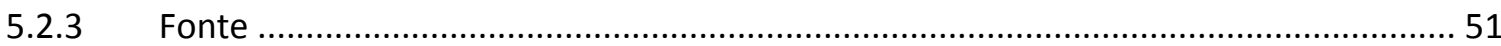

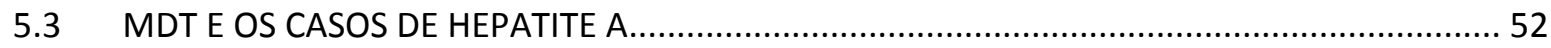

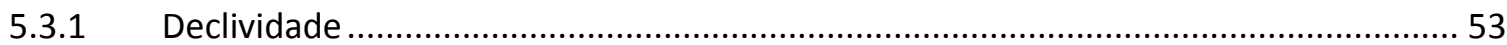

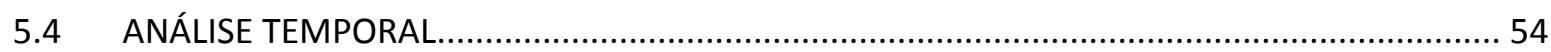

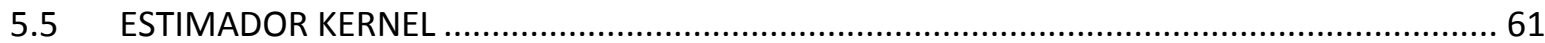

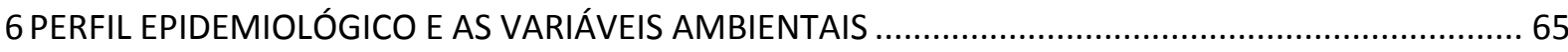

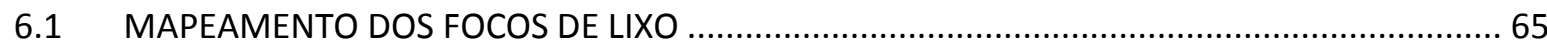

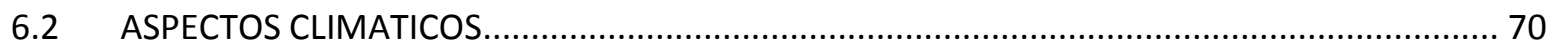

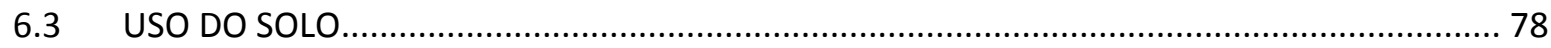

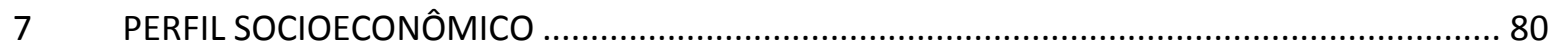

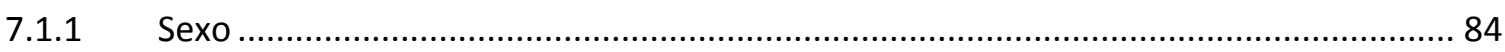

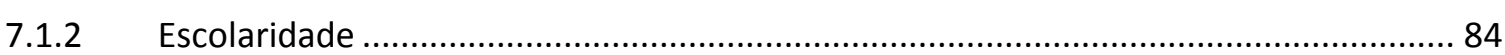

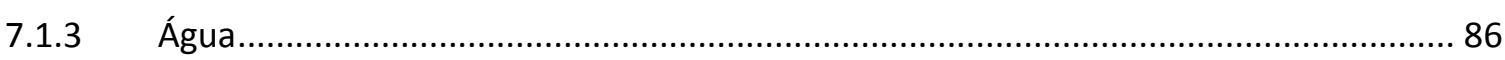

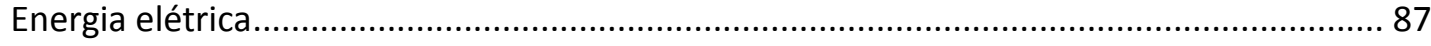

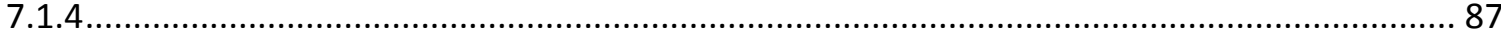

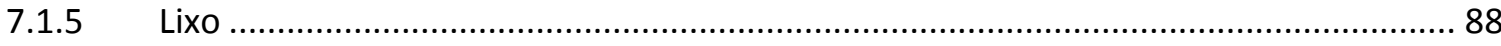

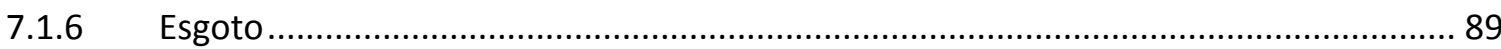

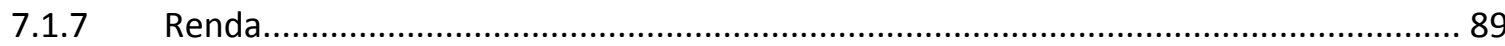

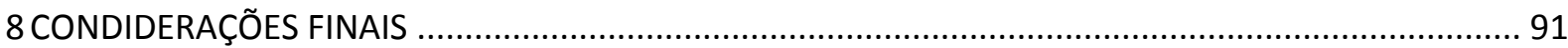

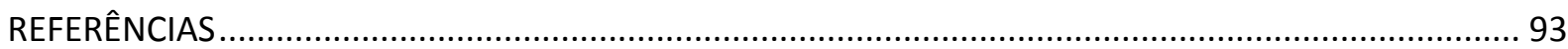




\section{INTRODUÇÃO}

A água é um dos recursos naturais de maior uso pelo homem. Esse recurso é utilizado na dessedentação humana, de animais, irrigação, geração de energia, higiene, lazer, diluição de efluentes industriais de uso mais intensivo e diversificado pelo homem, entre outros. Para cada forma possível de utilização da água há um padrão diferente de quantidade e qualidade do recurso. Apesar de sua capacidade natural de renovação em um curto período de tempo, a falta de políticas de controle e recuperação da água utilizada pelo homem pode comprometer outras aplicações do bem natural (MOTTA, 1998).

A água é essencial para a vida humana e é dispersa de forma heterogênea no espaço geográfico. Sua utilização ocorre de modo diferenciado pelos diversos atores sociais que compõem esse espaço. Diante dessa situação, as formas de análise do espaço tornam - se importantes para a discussão sobre a água e saúde. Um dos meios de verificar essa questão envolve o lugar, porção ou parte do espaço onde se passa o cotidiano e as experiências das pessoas (GURGEL et al. 2014).

Cerca de $10 \%$ da carga global de doenças é vinculada à má qualidade da água e a carências na disposição de excretas e na higiene (PRÜSS-USTIN et al. 2008). De acordo com Confalonieri et al. (2010) a água se relaciona com a saúde humana de diversas formas, dentre as quais se destaca como veículo de agentes microbianos causadores de infecções, como veículo de agentes tóxicos naturais ou antrópicos, como reservatório de vetores de doenças ou com os impactos físicos diretos (inundações) ou indiretos (danos à produção de alimentos ou à infraestrutura de saúde).

A prevalência de doenças de veiculação hídrica, principalmente na América Latina, África e Ásia representa um forte indicador da fragilidade dos sistemas públicos de saneamento. Essa fragilidade materializa-se na ausência de redes coletoras de esgoto e principalmente, na qualidade da água que é distribuída à população, quando há presença de sistemas de abastecimento (DANIEL, 2001).

O modo de acesso aos serviços adequados de água e esgoto é um importante determinante das condições de vida da população e da salubridade do meio ambiente, pois a preocupação com os impactos do meio ambiente sobre a saúde coletiva tem crescido tanto em países desenvolvidos como nos países em desenvolvimento (WHO, 2013). O 
desenvolvimento econômico e social gerado pela universalização do acesso aos serviços de saneamento e pela melhora nas condições de salubridade ambiental é importante para a gestão integrada de saúde (PRADO;MIAGOSTOVICH (2014).

Nesse sentido, torna-se importante o estudo das doenças envolvendo a epidemiologia, que tem por objetivo estudar a saúde-doença no âmbito dos fenômenos coletivos e carrega o desafio de desenvolver bases conceituais e metodológicas capazes de integrar o conhecimento biológico aos fenômenos sociais (POSSAS, 1989).

A Hepatite A é considerada uma infecção viral com distribuição mundial, transmitida principalmente pela via fecal-oral através da água e de alimentos contaminados. $\mathrm{O}$ agravo acomete em geral populações de regiões economicamente menos desenvolvidas, de baixos índices de saneamento e níveis de escolaridade (JACOBSEN, 2010). O vírus da Hepatite A (HAV, família Picornaviridae, gênero Hepatovirus) se localiza no meio ambiente e suas partículas podem ser estáveis por dias ou meses em água potável, água do mar, esgoto ou solo contaminado (SOBSEY, 1998; MEDRONHO 2003).

A forma de apresentação do agravo é esporádica e epidêmica e no passado, houve a tendência a recorrências cíclicas de epidemias de Hepatite A. Nos países em desenvolvimento e em lugares onde o saneamento é pobre e/ou deficitário, a infecção é comum e surge em pessoas com idade mais jovem. A infecção em geral é benigna e são raros os casos em que há evolução para formas mais agudas (OPAS, 1987).

A distribuição espacial e temporal de casos de uma determinada doença, nas áreas urbanas, pode sofrer a influência de fatores geográficos, climáticos, biológicos e antrópicos. As estatísticas de casos de doenças e suas co-variáveis são disponibilizadas em dados agregados, baseadas em unidades geopolíticas. Estas podem ser limitadas por setores censitários, bairros ou regiões administrativas (FORTES et al. 2004).

A região de Sobradinho, Distrito Federal, faz parte da região de saúde norte no atual sistema de regionalização do setor na unidade Federativa. Essa região abrange três regiões administrativas: Sobradinho, Sobradinho II e Fercal. 


\subsection{JUSTIFICATIVA}

Segundo Bosch et al. (1991), existe uma relação entre a qualidade da água e as epidemias causadas por vírus entéricos humanas, como o caso da Hepatite A. O agravo é uma infecção encontrada em todo o mundo e sua alta prevalência é associada a baixas condições socioeconômicas da população. Em regiões de renda elevada como Europa Ocidental, Austrália, Canadá, Nova Zelândia, Estados Unidos e Coréia do Sul a prevalência de anticorpos Anti-HVA difere de países em com renda média ou baixa em regiões da América Latina, Oriente Médio e a parte Oriental da Europa (WHO, 2012).

Estudos de soroprevalência indicam que o Distrito Federal é uma região de média endemicidade para Hepatite A. Na unidade federativa, assim como em outras regiões do Brasil, há uma associação inversa entre a soropositividade para o anti-HAV e as condições socioeconômicas no nível de área. As áreas onde a média de anos estudados é baixa e onde a cobertura da rede oficial de abastecimento de água ou da coleta de lixo é baixa tornam-se alvos prioritários para ações de controle do agravo (PEREIRA et al. 2010).

Nessa perspectiva, este trabalho surgiu de questionamentos e do interesse em verificar e explorar os casos de Hepatite A no Distrito Federal com foco na análise dentro das regiões administrativas, pois o tema é pouco explorado pela literatura. A escolha da região de Sobradinho foi motivada pelo histórico de ocupação e consolidação da região, pelas características físicas locais, e pelas variações nas condições socioeconômicas da população.

\subsection{OBJETIVOS}

\subsubsection{Objetivo geral}

Analisar a distribuição espacial dos casos confirmados de Hepatite A na região de Sobradinho por meio do foco epidemiológico em que os aspectos ambientais, sociais e econômicos são subsídios para a identificação do padrão de distribuição da doença. 


\subsubsection{Objetivos específicos}

Os objetivos específicos para atingir os objetivos do trabalho proposto são:

- Analisar a estrutura socioambiental da região de Sobradinho a fim de identificar as desigualdades espaciais na configuração local, por meio da relação entre os atributos do terreno e os indicadores socioeconômicos de setores habitacionais e aglomerados urbanos da região de Sobradinho /DF.

- Estudar a distribuição espaço temporal de Hepatite A na região de Sobradinho por meio de uma análise espaço-temporal no período de 2007 a 2015.

- Identificar as zonas de maior incidência de Hepatite A e sua correlação com os focos de lixo e com a hidrografia.

- Construir o perfil socioambiental da Hepatite A a partir do foco epidemiológico da área de estudo. 


\subsection{MODELO CONCEITUAL DA DISSERTAÇÃO}

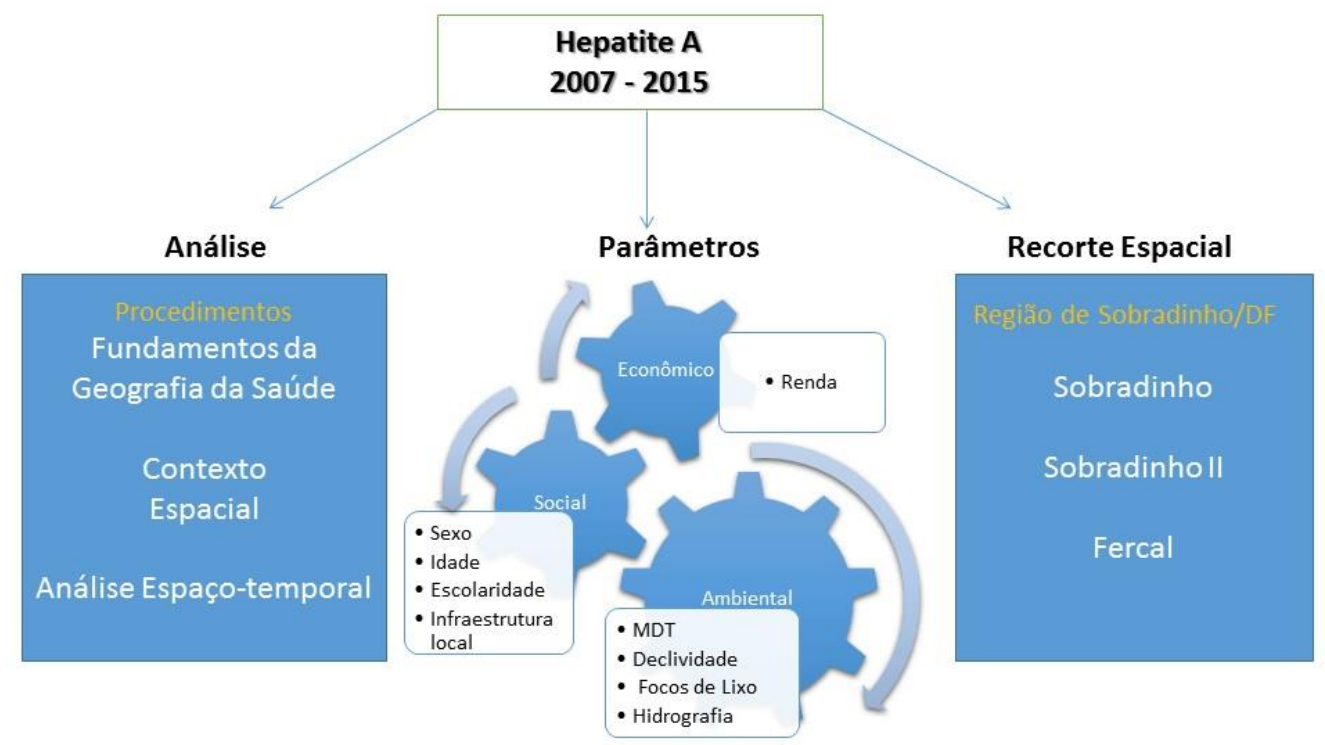

Figura 1 - Modelo Conceitual da Dissertação

\subsubsection{Estrutura da dissertação}

A dissertação tem sua estrutura dividida em capítulos. A primeira parte da dissertação aborda de forma geral o tema de pesquisa, sua pertinência e relevância. São apresentados os objetivos gerais e específicos, a questão de pesquisa, a justificativa e a hipótese de trabalho.

O capítulo 2 apresenta os materiais e métodos da pesquisa, onde é realizada a contextualização e a definição da área de estudo. Neste capítulo também se encontra a abordagem metodológica da pesquisa.

No capítulo 3 é apresentado o referencial teórico do trabalho, no qual é feita uma revisão bibliográfica com os principais temas que subsidiarão as análises e resultados da pesquisa de dissertação. As questões referentes à abordagem ambiental foram tratadas no capítulo 4. 
O capítulo 5 trata do perfil epidemiológico da Hepatite A na região de Sobradinho. O capítulo 6 refere-se à análise do perfil epidemiológico a partir das variáreis ambientais.

No capítulo 7 é tratada a questão do perfil socioeconômico dos moradores da área de estudo. A dissertação é finalizada com o capítulo 8, onde são realizadas as considerações finais e a conclusão do trabalho. 


\section{MATERIAIS E MÉTODOS}

\subsection{DEFINIÇÃO E CONTEXTUALIZAÇÃO DA ÁREA DE ESTUDO}

O Distrito Federal, segundo o último censo realizado pelo IBGE no ano de 2010, tem uma população de 2.570.160 habitantes, distribuídas nas 31 regiões administrativas ao longo de $5787,8 \mathrm{~km}^{2}$ de extensão com uma população predominantemente urbana. A região de Sobradinho, localizada na porção norte do DF compreende uma área de três regiões administrativas: Sobradinho, Sobradinho II e Fercal (Mapa 1).

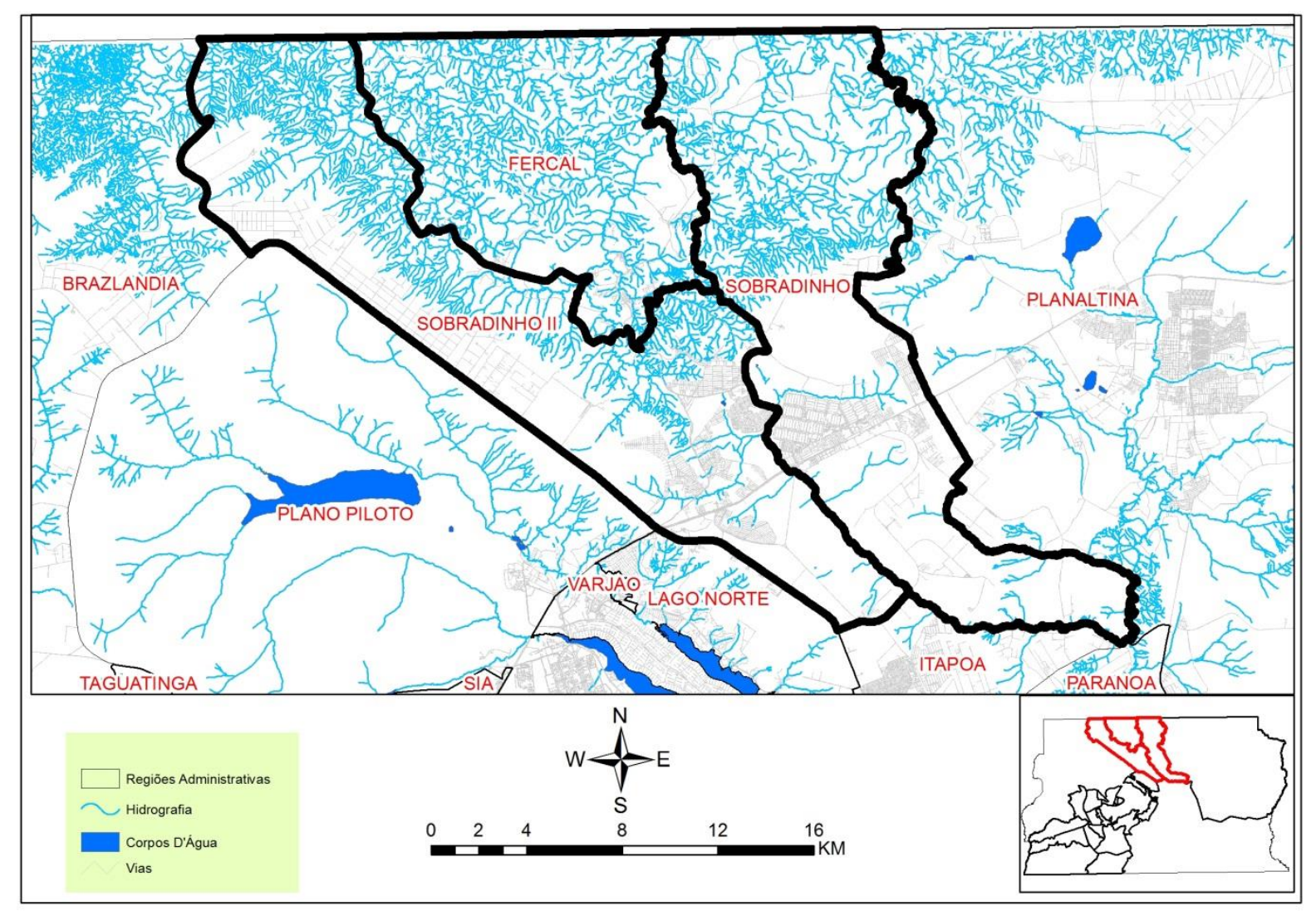

Mapa 1 - Área de estudo e a hidrografia local. Fonte: SITURB/SEGETH. Elaborado pelo autor. 
Este trabalho se propõe a realizar um estudo ecológico sobre a os casos de Hepatite A na região de Sobradinho por meio da distribuição espaço-temporal. Entende-se por estudo ecológico o estudo epidemiológico em que as unidades de análises e as variáveis preditivas correspondem ao nível populacional e não ao nível individual (CASTELLANOS, 1998). A escolha da região foi motivada por sua característica em abranger aglomerados urbanos em diferentes estágios de desenvolvimento. Essa característica implica na disposição de oferta dos serviços públicos, em questões socioambientais e econômicas, em especial pela diferença de acesso e oferta desses serviços em relação à necessidade demandada pela população.

O recorte geográfico da área de estudo é delimitado pela porção norte do Distrito Federal. A área de estudo é a região de Sobradinho, a qual é constituída atualmente por três regiões administrativas ${ }^{1}$ : Sobradinho - RA V, Sobradinho II - RA XXVI e Fercal - RA XXXI. Apesar das três RA's serem administrativamente independentes, há uma grande interação entre elas como, por exemplo, a busca de serviços de saúde entre a população dessas localidades. Os diferentes níveis de ocupação e desenvolvimento das RA'S resultam em diferentes níveis de acesso aos serviços públicos. Isso permite a influência de certa localidade perante outras, seja por meio de oferta de serviços, equipamento público, entre outros, conforme pode ser verificado nos estudos de Paviani (1985; 1991; 1996)

Sobradinho foi inaugurada em 13 de maio de 1960. Sua designação como região administrativa foi instituída pela lei $\mathrm{n}^{\mathrm{o}} 4.545$, de 10 de dezembro de 1964 para atender à demanda habitacional dos trabalhadores e de imigrantes vindos de outras áreas do país. Essa lei cria as primeiras administrações regionais do Distrito Federal, conforme consta:

\begin{abstract}
Art. 31. O Distrito Federal será dividido em 8 (oito) regiões administrativas, a saber: Taguatinga, Planaltina, Sobradinho, Braslândia, Gama, Jardim, Paranoá e Brasília.

Parágrafo único. A Região Administrativa compreenderá áreas urbanas, áreas de expansão urbana e áreas rurais a serem fixadas por decreto do Prefeito do Distrito Federal.
\end{abstract}

À medida que o adensamento urbano foi se consolidando no Distrito Federal, ocorreu o aumento de ocupações irregulares e invasões de terra ao redor de Brasília. Diante dessa realidade, o poder público propôs a criação de programas de erradicação de invasões e de criação de assentamentos para a população em todo o DF, intensificados durante o fim dos anos 80 e o início dos anos 90 (VASCONCELLOS, 1998; PAVIANI, 2009).

\footnotetext{
${ }^{1}$ As regiões administrativas de Sobradinho II (RA XXVI) e Fercal (RA XXXI) pertenciam à RA de Sobradinho antes de serem desmembradas. Sobradinho II foi emancipado em 2004 e a Fercal tornou-se região administrativa em 2012.
} 
Em Sobradinho, famílias de baixa renda cujas moradias se localizavam em áreas irregulares, como o caso das invasões do Ribeirão Sobradinho e Lixão foram beneficiadas com o Programa de Assentamento de População de Baixa Renda. Surge, assim, o núcleo de urbano de Sobradinho II. Nesse mesmo período surgem os primeiros condomínios irregulares (CODEPLAN, 2014). Em 27 de Janeiro de 2004 a localidade se tornou região administrativa pela instituição da Lei 3.314:

Art. 1 Fica criada a Região Administrativa de Sobradinho II.

Parágrafo único. Para a execução regionalizada das atividades da Administração do Distrito Federal mencionada no art. $1^{\circ}$, fica criada na estrutura organizacional do Distrito Federal, a Administração Regional de Sobradinho II - RA XXVI, órgão de direção superior, vinculada à Secretaria de Estado de Coordenação das Administrações Regionais para fins de controle e supervisão global.

A Fercal é o terceiro aglomerado urbano da área de estudo e a $31^{\mathrm{a}}$ região administrativa do Distrito Federal, criada pela Lei $n^{\circ} 4.795$, de 29 de janeiro de 2012. Antes de sua criação a Fercal foi vinculada às regiões Administrativas de Sobradinho e Sobradinho II. Apesar de ser a mais recente RA do DF, a região tem registros de atividades econômicas antes mesmo da inauguração de Brasília. Localizada na porção norte do Distrito Federal, a RA região é um importante polo econômico do DF, uma vez que abriga importantes fábricas de cimento e usinas de asfalto. A Fercal tem em seu entorno a Área de Preservação Ambiental - APA de Cafuringa e faz limite com as seguintes localidades: Sobradinho, a leste, Sobradinho II ao sul e a oeste e o município goiano de Planaltina de Goiás na porção norte.

A região é conhecida por ter sido ocupada e povoada ao longo das décadas sem o acompanhamento de políticas de planejamento e ordenamento territorial específico para a área. Essa ocupação ocorreu principalmente devido à incidência da indústria cimenteira, a qual ajudou na promoção e surgimento de atividades econômicas locais (OTTONI, 2013). Para o presente estudo será utilizado como parâmetro de recorte da área o limite das regiões administrativas do Distrito Federal, o qual contempla a poligonal de 31 Regiões Administrativas.

O instrumento de ordenamento territorial e ocupação que elenca diretrizes para a região administrativa de Sobradinho (Mapa 2) foi instituído pela Lei Complementar $\mathrm{n}^{\circ} 56$, de 30 de dezembro de 1997, denominado Plano Diretor Local da RA V - Sobradinho. As desigualdades socioespaciais dentro da RA já indicavam, no PDL, a necessidade de maior assistência nas áreas de saneamento básico, transporte e prestação de serviços públicos como investimento em comércio de primeira necessidade, policiamento e instalação de telefones 
públicos. Além destes, o estudo também instituiu diretrizes para a cobrança da instalação de equipamentos urbanos nas áreas urbanizadas (PDL, 1997).

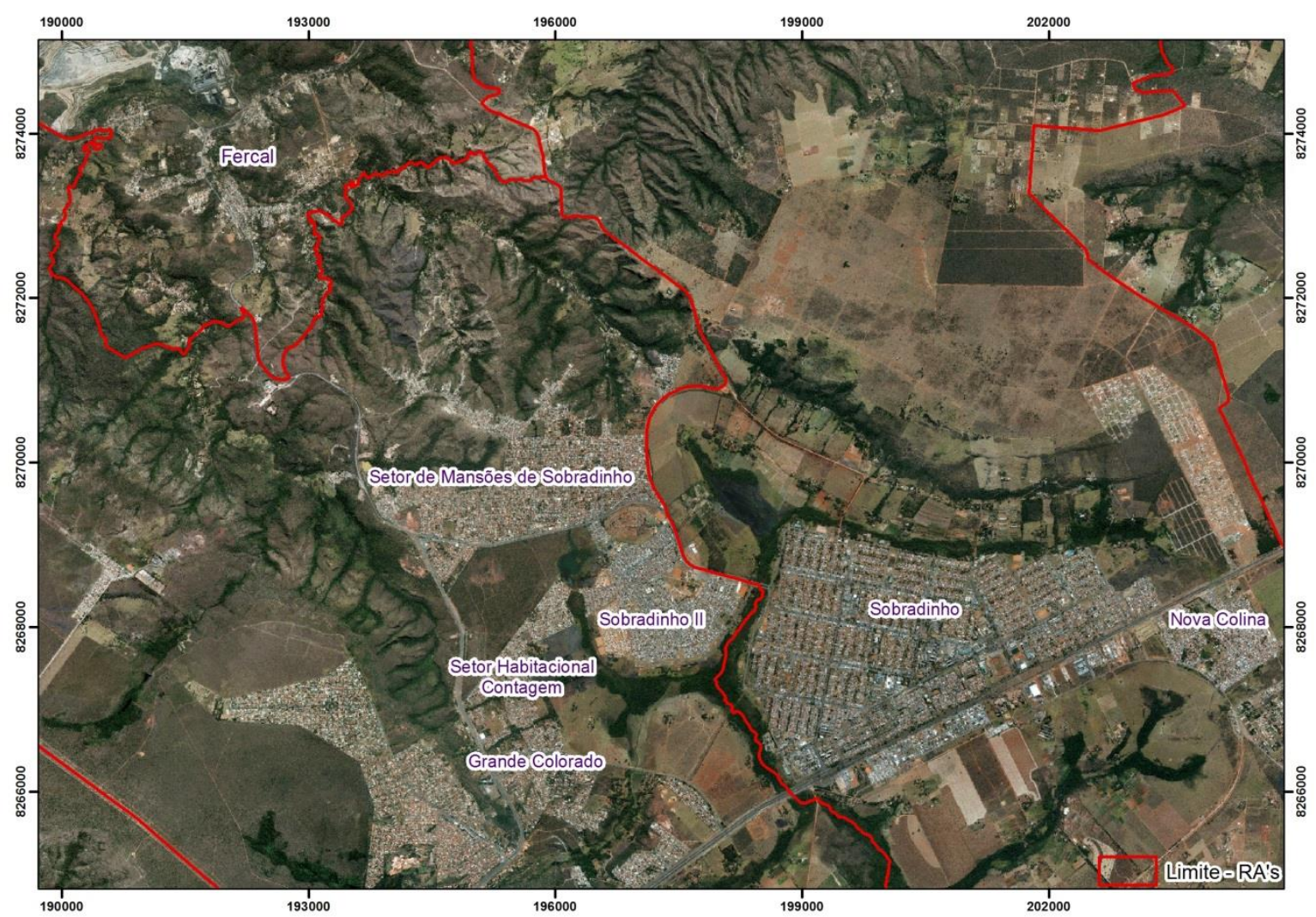

Mapa 2 - Setores habitacionais da região de Sobradinho. Fonte: SITURB e TERRACAP. Elaborado pelo autor.

\subsection{ABORDAGEM METODOLÓGICA}

Trata-se de uma pesquisa exploratória, desenvolvida na região de Sobradinho - DF, na qual estão inseridas três regiões administrativas: Sobradinho (RA V), Sobradinho II (RA XVII) e Fercal (RA XXXI). O termo "região de Sobradinho" foi inserido para delimitar o recorte espacial da pesquisa.

A primeira etapa da metodologia adotada consiste na revisão crítica da literatura para subsidiar as questões e discussões pertinentes aos objetivos da pesquisa. Neste contexto, a pesquisa documental tem grande relevância para o desenvolvimento do trabalho, pois a partir 
dela são coletadas informações para a geração de análises espaciais de Hepatite A na área de estudo.

O método adotado para o desenvolvimento da pesquisa é o ecológico consiste na estruturação de dados sobre os casos notificados e confirmados de Hepatite A. Para tanto, são essenciais as informações do agravo e também informações relacionadas ao universo da doença como forma de subsidiar uma análise de contexto local do contágio do HVA. As informações a serem estudadas têm caráter territorial, socioeconômico, socioambiental e da saúde. Essas informações foram obtidas em instituições governamentais e instituições não governamentais, publicações, e repositórios institucionais.

O estudo do perfil das áreas onde houve notificação de Hepatite A foi focado sob ótica ambiental, social e econômica por meio de dados secundários originados por órgãos diversos como:

Tabela 1 - Dados por Órgão de origem.

\begin{tabular}{|c|c|}
\hline Dados & Fonte \\
\hline Hepatite & SES/DF \\
\hline Curva de nível, Hidrografia, Pontos \\
Cotados & SITURB/DF \\
\hline Vias, Limites, Áreas de Regularização & SEGETH/DF \\
\hline Socioeconomia & CODEPLAN/IBGE \\
\hline Pluviometria & INMET \\
\hline Fotografias aéreas & TERRACAP \\
\hline
\end{tabular}

Além da utilização de dados secundários, foram gerados dados primários, como, a espacialização dos focos de lixo a partir de imagens de satélites. Esses dados foram produzidos em ambiente de Sistema de Informações Geográficas.

Por fim, foi feita a correlação observacional entre os aspectos ambientais, sociais e econômicos das áreas atingidas por notificações de Hepatite A. Foram realizados trabalhos de campo para entender o funcionamento dos serviços de saúde na região de Sobradinho e também para o reconhecimento do território nas regiões de maior fragilidade ambiental. 


\section{REVISÃO BIBLIOGRÁFICA}

\subsection{GEOGRAFIA DA SAÚDE}

A Geografia, enquanto ciência, sempre investigou as relações existentes entre o espaço e a doença. Os primeiros trabalhos empíricos remetem a Hipócrates (460-377 a.C.) com a secundarização do princípio mágico-religioso por meio da identificação de elementos físicos e a natureza dos lugares, esses considerados fatores causais para as enfermidades que atingiam o homem (NOSSA, 2012).

Um dos estudos clássicos da Geografia Médica refere-se ao trabalho de John Snow sobre a incidência de cólera na cidade de Londres (Figura 2). O autor fez uma relação entre o consumo de água pela população de Londres e a incidência de cólera (SNOW, 1990).

O início da interação entre Geografia e Epidemiologia ocorre com o parasitologista russo Y.N. Pavlovsky que apresentou, em 1939, a primeira formulação da teoria dos focos naturais das doenças humanas. Essa teoria consistia na abordagem ecológica da epidemiologia com uma aplicação coerente aos estudos de campo. Seus estudos tiveram como área de atuação as regiões semidesertas da União Soviética e o impacto epidemiológico na ocupação territorial do local (FERREIRA, 1991).

Pavlovsky desenvolveu a teoria com cunho ecológico e concebeu a noção de que o espaço era o cenário de circulação do agente infeccioso. Esse cenário, na teoria do autor, poderia ser natural, ou seja, sem o contato da ação humana ou aquele alterado pela ação do homem. O modelo do foco natural é fundamental para se analisar o espaço como categoria de análise (SILVA, 2000). 


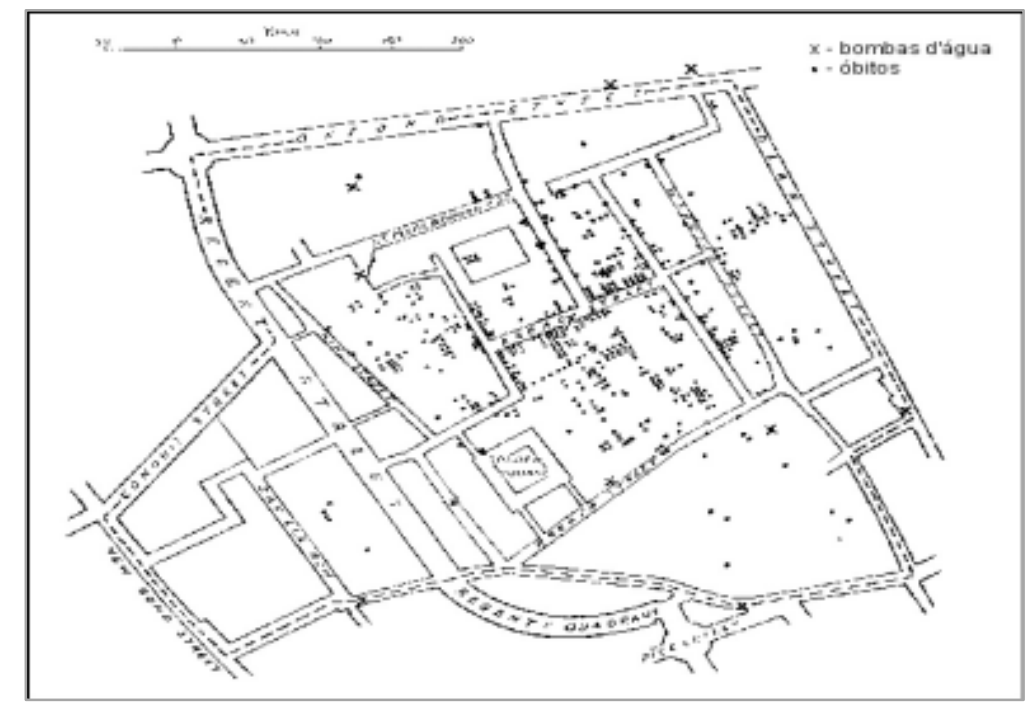

Figura 2 - Relação de bombas d'água e o número de mortes em Londres. Adaptado de Santos, Pina e Carvalho (2000)

A teoria do foco natural é aplicada a ambientes onde há favorecimento para a circulação de agentes, independente da presença e da ação do homem. $\mathrm{O}$ foco natural pode ocorrer nas mais diversas paisagens geográficas, desde que ocorra uma interação entre determinados biótipos (CEZERESNIA; RIBEIRO, 2000).

Outra importante contribuição para a Geografia da Saúde diz respeito ao geógrafo Max Sorre, cuja obra "Os Fundamentos da Geografia Humana" cria bases teóricas para a Geografia Médica, criando o chamado "Complexo Patogênico" no qual as abordagens das relações entre o homem e o meio envolvem a ação da natureza sobre o homem e a ação humana, de forma a modelar a natureza. Já o estudo de Pavlovsky é limitado ao estudo de doenças de animais transmissíveis ao homem, que tem seu foco natural (FERREIRA, 1991).

A partir da década de 1970, no Brasil, surge a influência das teorias de Milton Santos nos estudos de saúde pública, principalmente para tentar entender as nuances do processo saúde-doença e o contexto de urbanização do período. O espaço como "um conjunto indissociável de sistemas de ações e objetos" (SANTOS, 1988) e de onde se origina o território, exerce um importante papel na organização e promoção das práticas de vigilância em saúde (MONKEN;BARCELLOS, 2005). A categoria espaço de Milton Santos permitiu à Epidemiologia mudar o foco de análise centrada na doença para a análise das condições de ocorrência dessas doenças (SILVA, 1997). 
Essa perspectiva de trabalho envolve conceitos importantes da Geografia para a epidemiologia, como é o caso do espaço. Outra categoria de análise é o território, importante para a subsidiar o planejamento de ações e serviços de saúde.

\subsubsection{A importância do território}

O conceito de território não é exclusivo da Geografia, uma vez que é utilizado por outros ramos do conhecimento como Antropologia, Sociologia, Ecologia, entre outros. As mais recentes discussões sobre a definição de território consideram o componente cultural incorporada por ele. O território carrega de forma indissociável uma dimensão simbólica (ou cultural) e uma dimensão material, cuja natureza é predominantemente econômica (MONKEN et al. 2008).

De acordo com Haesbaert (2004) o conceito de território relaciona-se com o poder, tanto no sentido concreto, de dominação, quanto poder no sentido simbólico de apropriação. Para o autor, o território é sempre múltiplo, diverso e complexo enquanto "espaço-tempo vivido”. Nesse caso há uma busca para a superação da dicotomia material/ ideal por meio da concepção integrada do território.

Para Santos (1988) a configuração territorial é o território acrescido dos conjuntos de objetos existentes sobre ele, definida por objetos naturais ou artificiais. Essa configuração é um todo, formada pela constelação de recursos naturais e recursos criados, arranjadas em sistema.

Segundo Monken et al. (2008) o território é na maior parte das vezes utilizado de forma estratégica para a coleta e organização de dados sobre ambiente e saúde, mas há de se manter clareza sobre a transcendência de processos sociais e ambientais nos limites territoriais. Ou seja, nem o ambiente pode ser completamente conscrito dentro dos limites de um território tampouco os processos sociais se restringem a esses limites.

No campo da saúde o território tem grande importância na dinâmica da vigilância e uso de serviços de saúde. O território de um distrito sanitário ou de um município é caracterizado por apresentar uma população específica. Esse espaço mostra, além de uma extensão geométrica, um perfil demográfico, epidemiológico, administrativo, tecnológico, político, social e cultural, que o caracteriza como um território em construção permanente. (MENDES, 1993). 
Os delineamentos desses perfis são fundamentais para se estudar, analisar e modelar dados de saúde, pois contribui e subsidia análise de tendências, e padrões de incidências de um determinado agravo, considerando indicadores socioeconômicos de uma determinada população distribuída no território (CARVALHO; SOUZA-SANTOS, 2005).

Percebe-se, portanto, a existência de afinidades entre o campo da saúde e aspectos da Geografia. Essa convergência permite abordagens geográficas ao campo da saúde.

\subsection{GEOPROCESSAMENTO E SAÚDE}

A compreensão da distribuição de dados espaciais provenientes de fenômenos que ocorrem no espaço representa um grande desafio para diversas áreas, tais como saúde, ambiente, agronomia entre outras. O uso dos Sistemas de Informação Geográfica permite a visualização espacial de variáveis diversas, como a população de indivíduos ou os índices de qualidade de vida por meio de um banco de dados de uma base geográfica (CÂMARA et al. 2002). Em um nível tecnológico, o desenvolvimento de um SIG permite ofertar um amplo conjunto de estrutura de dados e algoritmos que possibilitam representar a grande diversidade e complexidade do espaço (CÂMARA et al., 2001).

Segundo Maguire (1991), os Sistemas de Informação Geográfica são utilizados por um heterogêneo grupo de indivíduos e organizações para uma grande variedade de aplicações. Um SIG é concebido como uma coleção integrada de hardware, software, dados e pessoas operando em um contexto institucional. Atualmente é crescente o uso de ferramentas de geoprocessamento para a análise integrada de dados de saúde. A espacialização das informações contidas em bancos de dados tabulares permite o desenvolvimento de variados modelos, permitindo a compreensão de aspectos relativos ao mapeamento e tendência de agravos. Isso possibilita a tomada de decisões de acordo com dados e critérios passíveis de representação espacial, o que corrobora para o entendimento facilitado dos processos de saúde.

De acordo com Barcellos \& Santos (1997) as técnicas de geoprocessamento são utilizadas para a análise, geração e manipulação e sobreposição entre diferentes camadas de dados. Esses dados devem ser agregados a unidades espaciais, de forma a permitir a agregação dos mesmos. No campo da saúde e ambiente, a escolha dessas unidades se baseia 
em critérios como: delimitação sócio-política de grupos, presença e qualidade do registro das unidades em banco de dados, homogeneidade interna dos fatores em análise, reconhecimento da unidade espacial pela população e escala de observação. Para os autores, no campo da saúde e ambiente o município reúne boas condições para ser utilizado como unidade espacial de análise por sua referência em dados primários em sua autonomia administrativa. O SIG é um importante instrumento de planejamento, monitoramento e avaliação das ações de saúde.

A variável espaço contém uma grande importância no campo da saúde, pois esse elemento dispõe da interpretação e explicação dos processos de saúde desde os estudos da topografia médica, entre os séculos XVIII e XIX até as concepções modernas de Geografia da Saúde. Diversas áreas do conhecimento se beneficiaram com as técnicas de geoprocessamento, manipulação e edição de dados geográficos (NOSSA, 2012). Como exemplo, a sobreposição e o uso desagregado de dados torna-se útil para a formulação de hipóteses e indagações, além da possibilidade de realizar análises com variáveis ambientais (CARVALHO et al., 2000).

A possibilidade de utilizar a sobreposição de informações e desagregações de dados permite trabalhar com diferentes unidades administrativas, além de possibilitar a geração de hipóteses, indagações e associações entre os eventos estudados e análises ecológicas. Ao se analisar a distribuição espacial dos agravos ocorre a possibilidade de se determinar padrões de situação de saúde, disparidades espaciais geradores de áreas de risco e incidências de eventos de enfermidades (SANTOS et al., 2000)

O setor saúde, em especial a vigilância e os serviços de controle revelam no espaço geográfico uma dimensão de análise importante, cuja influência foi dada pela disciplina Geografia Médica com seus croquis de localidades. Esses trabalhos foram produzidos pelo Setor de Cartografia da Superintendência de Campanhas de Saúde Pública - SUCAM (BARCELLOS; RAMALHO, 2002).

No Brasil, o setor de saúde detém um enorme banco de dados de informações diversas, armazenados em vários sistemas de informações, sendo uma rica fonte para diversas análises, seja nas esferas municipal, estadual ou federal. (BARCELLOS \& RAMALHO, 2002). É possível, portanto, elencar, agregar e cruzar uma série de dados por meio de análises históricas para uma grande variedade de aplicações e estudos.

O SINAN é um dos mais importantes bancos de dados em saúde. Criado no início da década de 90, o Sistema de Informações de Agravos e Notificação foi concebido com a finalidade de fornecer informações sobre os agravos em todo o território nacional, de forma a 
subsidiar ações nas esferas municipal, estadual e federal. Seu objetivo é armazenar informações de notificação compulsória com fichas de notificação e investigação, sendo permitida a adequação do sistema ao perfil epidemiológico de diferentes populações. (BRITTO 1993; LAGUARDIA et al. 2004).

\subsubsection{Análise Kernel}

A análise espacial tem como referência um conjunto de procedimentos dos quais a finalidade é a escolha de um modelo inferencial, considerando a relação espacial existente em um fenômeno. A análise exploratória e de visualização de dados, comumente presentes em mapas, permitem descrever a distribuição de variáveis, a identificação de situações atípicas e a busca de padrões na distribuição espacial (CÂMARA et al, 2002).

Uma das técnicas de geoprocessamento mais difundidas na análise espacial para saúde é o uso do estimador Kernel. A estimativa Kernel é uma técnica de interpolação exploratória cujo resultado é uma superfície de densidade para a identificação visual de "áreas quentes". A ocorrência de uma área quente diz respeito à concentração de eventos, indicando uma aglomeração em uma distribuição espacial (BARCELLOS et al, 2007). Em modelagem, o estimador de Kernel tem a função de gerar uma grade em que cada célula tem um valor de intensidade, densidade, razão entre atributos etc. O resultado do valor obtido será uma medida de influência das amostras na célula (CARNEIRO, 2005).

Por meio de um ajuste da função bi-dimensional dos eventos - dimensional sobre os eventos considerados, compõe-se uma superfície na qual o valor será proporcional à intensidade de amostras por unidade de área (Figura 3) (CÂMARA; CARVALHO, 2004). 


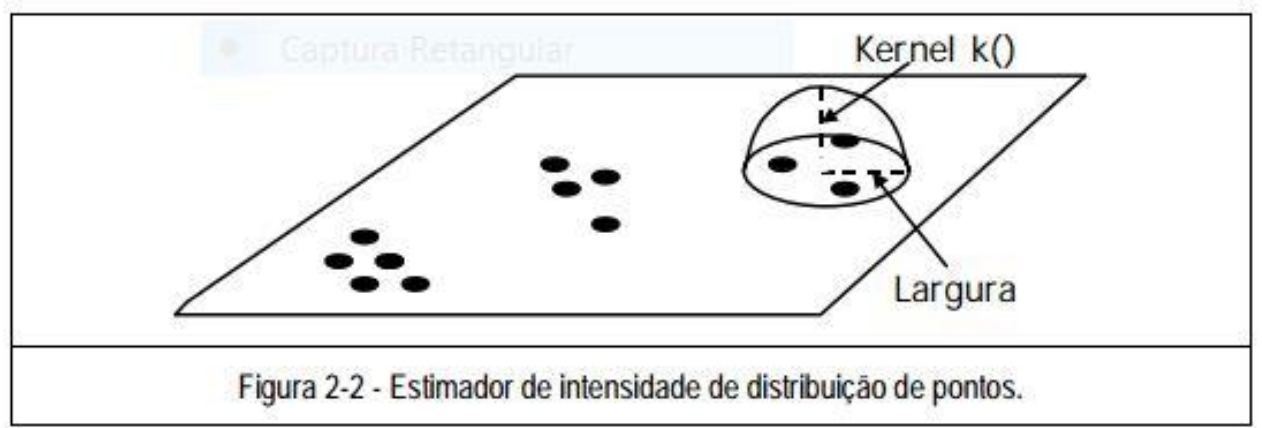

Figura 3 - Estimador de intensidade de distribuição de pontos. Adaptado de CÂMARA; CARVALHO, 2004).

De acordo com DRUCK et al. (2004) o Kernel é um estimador cujos parâmetros básicos são: (a) um raio de influência que define a vizinhança do ponto a ser interpolado; (b) uma função de estimação com propriedades para a suavização do fenômeno.

\subsection{O USO DOS SERVIÇOS DE SAÚDE}

O conceito de uso de serviços de saúde diz respeito ao contato direto e indireto com os serviços de saúde. A averiguação de desigualdades regionais no acesso aos serviços de saúde busca definir as unidades de observação, cuja característica inclui, em seus limites geográficos, a maior parte dos descolamentos dos indivíduos na busca dos atendimentos. (CARVALHO; SOUZA-SANTOS, 2005).

As áreas de cobertura de unidades de saúde podem ser chamadas de "mercados", se definidas com base na origem geográfica dos usuários (CARVALHO; SOUZA-SANTOS, 2005). Para Unglert (1995) o acesso à saúde está vinculado às condições de vida, habitação, educação e acessibilidade aos serviços. Segundo a autora, essa vinculação vai além dos aspectos geográficos do acesso, pois abrange também os componentes econômicos e culturais da população. As necessidades de saúde da população são muito maiores do que as que podem ser atendidas com a garantia de cobertura dos serviços de saúde (MORAES; JORDÃO, 2002). 
Ao se analisar as regiões de acordo com seu uso ou acesso aos serviços de saúde, podem - se realizar a comparação de formas diversas de obtenção de assistência, de acordo com a complexidade do procedimento e as alternativas existentes, assim como a área de cobertura dos serviços e sua responsabilidade sobre a qualidade da prestação do serviço (CARVALHO; SOUZA-SANTOS, 2005).

O Sistema de Saúde do Distrito Federal pautou, a partir de 2015, uma nova organização territorial, sob duas dimensões: as regiões administrativas e as regiões de saúde. A divisão do DF em regiões de saúde foi constituída sob os parâmetros dos limites territoriais, identidades culturais, aspectos socioeconômicos e de redes de comunicação e infraestrutura em transportes por meio do agrupamento das RA's. Foram criadas 7 regiões de saúde (Mapa 3), com o objetivo de descentralizar o atendimento à assistência e saúde (SES, 2016).

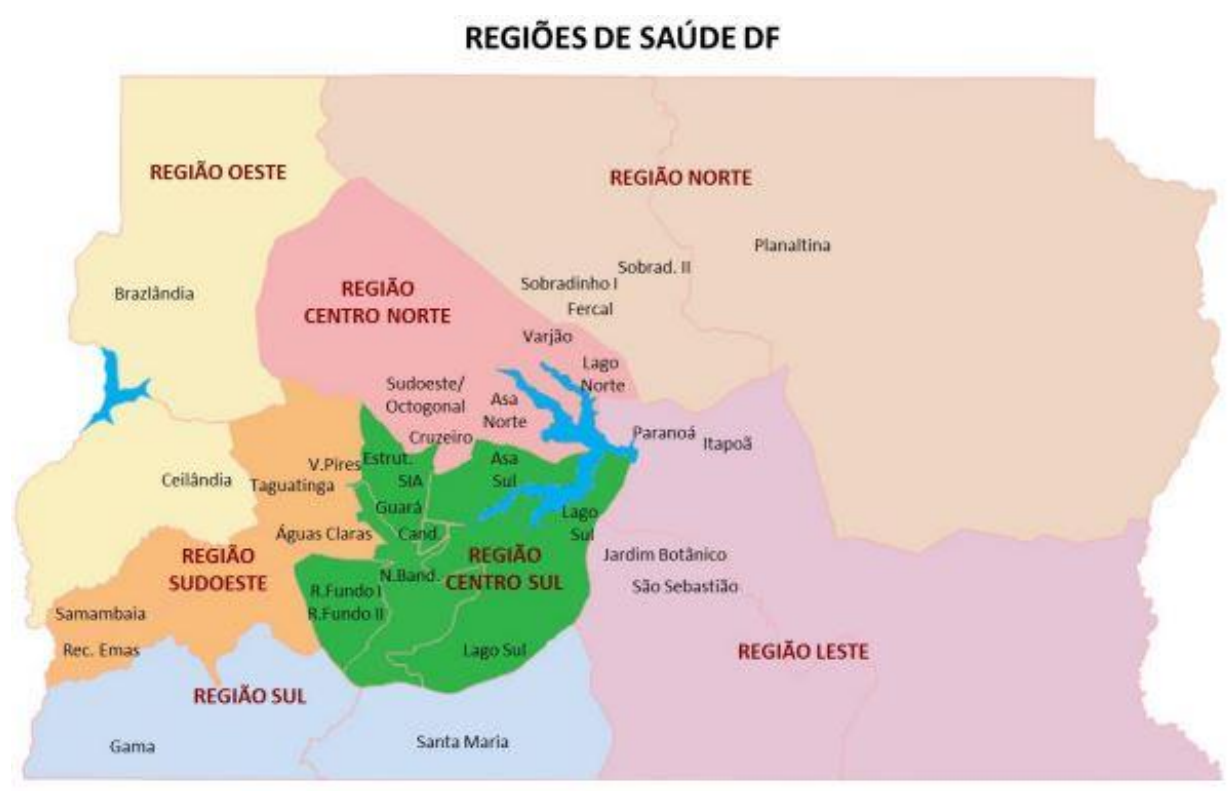

Mapa 3 - Regiões de Saúde do DF. Fonte: SES

Segundo TRAVASSOS \& MARTINS (2004), citando Pineal e Deveu, relata que a motivação para a utilização dos serviços de saúde pela população é relacionada aos seguintes fatores:

- $\quad$ Necessidade de saúde: nível de gravidade, urgência e morbidade.

- Aos usuários: perfil socioeconômico, demográfico, cultura e psíquico da população;

- Aos prestados de serviços: características demográficas, experiência profissional, tempo de graduação, características psíquicas; 
- A organização: disponibilidade de recursos, oferta de médicos, hospitais, ambulatórios;

- A Política.

A utilização de serviços de saúde ocorre devido às necessidades e o comportamento dos indivíduos diante dos problemas de saúde, além das formas e recursos disponíveis para a população, incluídas a estrutura administrativa e as formas de pagamento. (Travassos; Martins, 2004). Esses fatores são importantes para entender a motivação para o uso ou não dos serviços de saúde.

Os serviços de saúde, ofertados em um determinado território, contêm uma ligação direta com os meios de acesso a esses serviços. Para Donabedian (1973) o conceito de acessibilidade diz respeito à capacidade de oferta de serviços em relação à capacidade de produção desses serviços e de absorção das necessidades de saúde de uma população. Andersen (1995) propôs um modelo comportamental nos anos 60 em que busca descobrir as condições que facilitam ou dificultam a utilização dos serviços de saúde pelos indivíduos, bem como medir os níveis de acesso a esses serviços. Para o autor, acesso se relaciona a um componente do sistema de saúde vinculado à entrada nesse serviço.

Inicialmente o modelo do uso de serviços de saúde tinha como foco a família como unidade de análise. Posteriormente houve uma mudança: o foco foi mudado para indivíduo devido à dificuldade em criar medidas que considerassem a potencial heterogeneidade dos membros da família (ANDERSEN, 1995).

A regionalização dos serviços de saúde influencia diretamente nos níveis de acesso aos serviços de saúde, pois a abordagem descentralizadora dos sistemas de saúde nas diversas esferas políticas busca facilitar o acesso e à gestão da população aos serviços necessários à manutenção da saúde.

O contexto dos serviços de saúde e suas formas de acesso são importantes devido à possibilidade de análise de desigualdades regionais, decorrentes da oferta ou prestação desses serviços. O uso dessas informações permite, também, a sistematização do estado da arte de metodologias voltadas a análises espaciais em saúde pública. As áreas de cobertura de unidades de saúde baseadas na origem geográfica dos usuários podem ser denominadas como "mercados" destas unidades. Estes mercados constituem-se a partir de aspectos de acesso viário e histórico. (CARVALHO; SOUZA-SANTOS, 2005). Portanto, a 
identificação das áreas de cobertura dos serviços de saúde possibilita a agregação de informações para subsidiar estudos sobre a incidência de agravos na população.

\subsection{EPIDEMIOLOGIA E A RELAÇÃO ESPAÇO-TEMPO}

Entende-se por epidemiologia o estudo da distribuição e determinantes de doenças ou condições vinculadas à saúde em uma determinada população. Os estudos epidemiológicos se dividem em dois: os estudos experimentais e estudos observacionais (LIMA-COSTA; BARRETO, 2003).

Os estudos observacionais são subdivididos em descritivos e analíticos. O primeiro grupo considera a distribuição das doenças e as condições de saúde com base no tempo, no lugar e as características dos indivíduos. Os estudos analíticos se baseiam na associação entre a exposição e uma doença ou uma condição de saúde. Esse grupo apresenta quatro enfoques

distintos. Essas abordagens são ecológicas, seccionais, caso-controle e coorte (LIMACOSTA; BARRETO, 2003).

O método epidemiológico é o método científico aplicado aos problemas de saúde da população humana. Nele são aplicados conhecimentos de outros ramos do saber, tais qual a biologia, matemática, antropologia, economia, entre outros. A multidisciplinariedade da epidemiologia permite se valer das bases das ciências biológicas e das ciências humanas (WALDMAN, 1998).

No contexto da distribuição das doenças a tríade "pessoa-tempo-lugar" é uma ferramenta importante para analisar fenômenos em epidemiologia (MACMAHON; PUGH, 1970; LILIENFELD; LILIENFELD, 1980).

A descrição de doenças na epidemiologia utiliza categorias básicas como a distribuição espacial, a distribuição temporal e a distribuição com atributos pessoais. A descrição aprofundada sobre o comportamento de uma doença permite a formulação de hipóteses causais, além de possibilitar, também, a analogia nos estudos de novas e antigas doenças (WERNECK, L; STRUCHINER, C, 1997).

Werneck \& Struchiner, (1997) relatam sobre a existência de uma lacuna nos estudos de agregação espaço-temporal, pois a ausência de sistematização para a que novas 
metodologias e campos de aplicação serviram de motivação para o encontro de novas proposições exploratórias. O estabelecimento de nexos espaço - temporais são essenciais para averiguar processos dinâmicos envolvidos com doenças infecciosas ou advindos de fatores ambientais efêmeros (MARSHALL, 1991).

A análise espaço-temporal apresenta grandes contribuições para o estudo epidemiológico dos agravos ao possibilitar a identificação de padrões em uma determinada porção do território, durante um intervalo de tempo.

\subsection{SANEAMENTO AMBIENTAL}

No contexto da análise dos territórios há uma relação direta entre a exposição a riscos ambientais e a precariedade no acesso aos serviços públicos. A falta de uma infraestrutura urbana adequada expõe a população a riscos ambientais, como por exemplo, as doenças de veiculação hídrica (JACOBI, 1995).

O saneamento básico é um conjunto de ações de abastecimento de água, esgotamento e coleta de lixo. É um direito dos cidadãos e um componente imprescindível para a qualidade de vida. O fornecimento de água em quantidade e qualidade suficiente para suprir às necessidades da população advém do processo de urbanização e adensamento populacional (ANDREAZZI et al., 2007).

Desde as antigas civilizações o saneamento tem sido associado à saúde humana, se desenvolvendo de acordo com a evolução das diversas civilizações. A civilização grecoromana fez muitas referências às práticas sanitárias e higiênicas vigentes e a constituição do conhecimento relativo à associação entre os cuidados e o controle de doenças. Durante a idade média houve um retrocesso nas conquistas no desenvolvimento sanitário de até então. Então surgiram recorrentes epidemias (FUNASA, 2007).

Dessa forma, o desenvolvimento urbano acelerado na segunda metade do século XX fez com que a população se concentrasse em espaços reduzidos gerou uma competição para a exploração de recursos naturais, causando a modificação/destruição de ecossistemas naturais. (TUCCI, 2008). 
A degradação e a escassez de recursos naturais são graves problemas de saúde pública. Apesar do aumento do número de pesquisas em diagnóstico e tratamento de ambientes aquáticos, inexistem soluções instantâneas para a mitigação da degradação ambiental (MORAES; JORDÃO, 2002).

Os maiores problemas sanitários que afetam a população mundial estão relacionados ao meio ambiente e as condições inadequadas de saneamento. Exemplo disso está na incidência de diarreia, apresentando um coeficiente de incidência de cerca de quatro bilhões de casos por ano (FUNASA, 2007).

A qualidade das águas depende de fatores geológicos, geomorfológicos e de cobertura vegetal da bacia de drenagem, da dinâmica dos ecossistemas terrestre e aquático de águas doces e também das ações antrópicas. O modo de agir do homem pode influenciar na qualidade da água, seja pelo lançamento de cargas nos ecossistemas híbridos, alteração do uso do solo ou por modificações no sistema fluvial (TUCCI, 2001).

As águas urbanas abrangem o sistema de abastecimento de água e esgoto sanitários, além de drenagem urbana, gestão de sólidos e enchentes ribeirinhas. O sistema de abastecimento de água tem como objetivo promover a saúde e a conservação ambiental como forma de qualidade de vida (TUCCI, 2008). Assim, a qualidade de vida de uma população está diretamente relacionada com o nível de acesso e qualidade dos recursos hídricos da qual ela obtém.

O contexto da qualidade da água e o saneamento apresentam forte relação com a incidência de doenças hídricas, pois a presença ou ausência de infraestrutura adequada para a população pode ser um fator determinante para se criar condições para a proliferação desses agravos.

\subsection{DOENÇAS DE VEICULAÇÃO HÍDRICA}

Entre os maiores desafios a serem enfrentados pelas próximas gerações, os quais ameaçam o futuro da humanidade, está relacionado à questão da disponibilidade de água para o consumo humano e para a produção de alimentos. O crescimento populacional demanda uma crescente necessidade de maiores quantidades de água para atividades industriais e 
agrícolas (FRANCO, 2007). O crescente processo de degradação das fontes de água doce utilizadas pelo homem como rios, fontes, riachos, poços e lagos sofrem da deposição de esgotos in natura, fezes de animais e emissão de efluentes resultantes das atividades industriais (DOWBOR, 2005).

De acordo com Cairncross \& Feachem (1990) as infecções geradas pela água podem ser transmitidas em quatro grupos (Tabela 2) de categorias distintas, quais sejam:

1) Transmissão hídrica, onde o patogênico está localizado na água ingerida;

2) Transmissão vinculada à higiene;

3) Transmissão baseada na água;

4) Transmissão por meio do inseto vetor.

Tabela 2 - Patologias de doenças hídricas. Fonte: Cairncross \& Feachem (1990) e Heller (1997)

CLASSIFICAÇĀO AMBIENTAL DAS INFECCOOES RELACIONADAS COM A ÁGUA

\begin{tabular}{|c|c|}
\hline CATEGORIA & INFECÇÁO \\
\hline $\begin{array}{l}\text { 1. Feco-oral (transmissâo hidrica ou } \\
\text { relacionada com a higiene) }\end{array}$ & $\begin{array}{l}\text { Diarreias e disenterias } \\
\text { Disenteria amebiana } \\
\text { Balantidiase } \\
\text { Enterite campylobacteriana } \\
\text { Colera } \\
\text { Diarreia por Escherichia coli } \\
\text { Giardiase } \\
\text { Diarreia por rotavirus } \\
\text { Salmonelose } \\
\text { Disenteria bacilar } \\
\text { Febres entericas } \\
\text { Febre tifoide } \\
\text { Febre paratifoide } \\
\text { Poliomielite } \\
\text { Hepatite A } \\
\text { Leptospirose } \\
\text { Ascaridiase } \\
\text { Tricuriase }\end{array}$ \\
\hline $\begin{array}{l}\text { 2. Relacionada com a higiene } \\
\text { (a) Infecçoes da pele e dos olhos }\end{array}$ & $\begin{array}{l}\text { Doenças infecciosas da pele } \\
\text { Doenças infecciosas dos olhos }\end{array}$ \\
\hline (b) Outras & $\begin{array}{l}\text { Tifo transmitido por pulgas } \\
\text { Febre recorrente transmitida por pulgas }\end{array}$ \\
\hline $\begin{array}{l}\text { 3. Baseada na água } \\
\text { (a) Por penetraçáo na pele } \\
\text { (b) Por ingestáo }\end{array}$ & $\begin{array}{l}\text { Esquistossomose } \\
\text { Difliobotriase e outras infecobles por helmintos }\end{array}$ \\
\hline $\begin{array}{l}\text { 4. Transmissáo através de inseto vetor } \\
\text { (a) Picadura proximo a água } \\
\text { (b) Procriam na água }\end{array}$ & $\begin{array}{l}\text { Doença do sono } \\
\text { Filariose } \\
\text { Malária } \\
\text { Arboviroses } \\
\quad \text { Febre amarela } \\
\quad \text { Dengue } \\
\text { Leishmaniose* }\end{array}$ \\
\hline
\end{tabular}


As doenças de veiculação hídrica representam um dos principais problemas de saúde pública nos últimos 25 anos, apesar da adoção de medidas restritivas em alguns países e do desenvolvimento de tecnologias para tratamento (SMITH et al. 2006).

No presente estudo escolheu-se como objeto de estudo a Hepatite A e devido à importante relação entre os fatores socioeconômicos com a incidência do agravo. O outro fator adotado para a análise desses agravos diz respeito à disponibilidade de dados da Secretaria de Estado de Saúde do Distrito Federal.

A Hepatite A é um agravo oriundo direta ou indiretamente da água. Assim, tem-se importantes focos dessas doenças no Brasil, devido à qualidade de fornecimento de recursos hídricos, a poluição de corpos d'agua e o depósito de resíduos sem o tratamento adequado. (BRASIL), 2009.

\subsection{HEPATITE A}

As hepatites virais são causadas por diferentes agentes etiológicos. Sua distribuição é universal e tem um comum o hepatotropismo. Existem muitas semelhanças entre as hepatites no quesito clínico-laboratorial, porém elas se diferem quanto à epidemiologia e à sua evolução (FERREIRA; SILVEIRA, 2004). As Hepatites virais são provocadas por diferentes vírus hepatotrópicos e varia de acordo com o agente etiológico. Os indivíduos infectados podem ter complicações agudas e crônicas de infecção (BRASIL, 2010). As hepatites virais são doenças causadas por agentes etiológicos diversos, de distribuição universal e têm em comum o hepatotropismo e são semelhantes do ponto de vista clínico-laboratorial, porém se distinguem em epidemiologica quanto à sua evolução (FERREIRA; SILVEIRA, 2004).

A Hepatite A é transmitida pelo vírus A (VHA) e é considerada uma doença viral aguda. Assim como outras doenças como a Leptospirose, pode ser uma contraída por meio de veiculação hídrica. Também pode ser adquirida por meio do contato fecal-oral, além de ser incidente em regiões de más condições sanitárias e higiênicas (BRASIL, 2009).

A distribuição da Hepatite A é universal, sendo endêmica em muitas regiões. A prevalência da infecção depende do grau de higiene e das facilidades sanitárias disponíveis para as populações (PEREIRA; GONÇALVES, 2003) 
O vírus da Hepatite A (VHA) é o principal agente etiológico de hepatite, causando morbidez em países desenvolvidos e subdesenvolvidos. O vírus da Hepatite A é extremamente estável, transmitido pela via fecal-oral e de pessoa a pessoa pela comida ou água contaminada (VILLAR; DE PAULA; GASPAR, 2002). A Hepatite A é transmitida pelo vírus A (VHA) e é considerada uma doença viral aguda. Assim como outras doenças como a Leptospirose, pode ser uma contraída por meio de veiculação hídrica. Também pode ser adquirida por meio do contato fecal-oral, além de ser incidente em regiões de más condições sanitárias e higiênicas. (BRASIL, 2009).

A distribuição da Hepatite A é universal, sendo endêmica em muitas regiões. A prevalência da infecção depende do grau de higiene e das facilidades sanitárias disponíveis para as populações (PEREIRA; GONÇALVES, 2003).

A transmissão de Hepatite A em países subdesenvolvidos ocorre pela ingestão de água, alimentos e objetos contaminados, após os oito meses de idade, pois nesse momento os anticorpos maternos começam a desaparecer. Nos países em desenvolvimento ou nos países desenvolvidos a transmissão precoce da doença diminui à medida que as condições higiênicas melhoram (PEREIRA; GONÇALVES, 2003). O HVA é altamente endêmico em países onde as condições sanitárias não são satisfatórias. Somente no ano de 2013 o vírus da Hepatite A causou a morte de 14.900 pessoas em todo o mundo (WHO, 2016).

A Hepatite A é uma doença comumente vinculada às questões sanitárias nas quais a população de uma determinada região está inserida. De acordo com Santos et al. (2002) a melhora nas condições sanitárias e o fornecimento de água de melhor qualidade foram responsáveis pela queda do nível endêmico da doença em muitos países em desenvolvimento.

O Brasil apresenta elevados índices de transmissão de Hepatites A (figura 4) em decorrência das deficientes condições de saneamento básico para uma representativa parte da população, inclusive em grandes centros urbanos (SANTOS et al., 2005). 


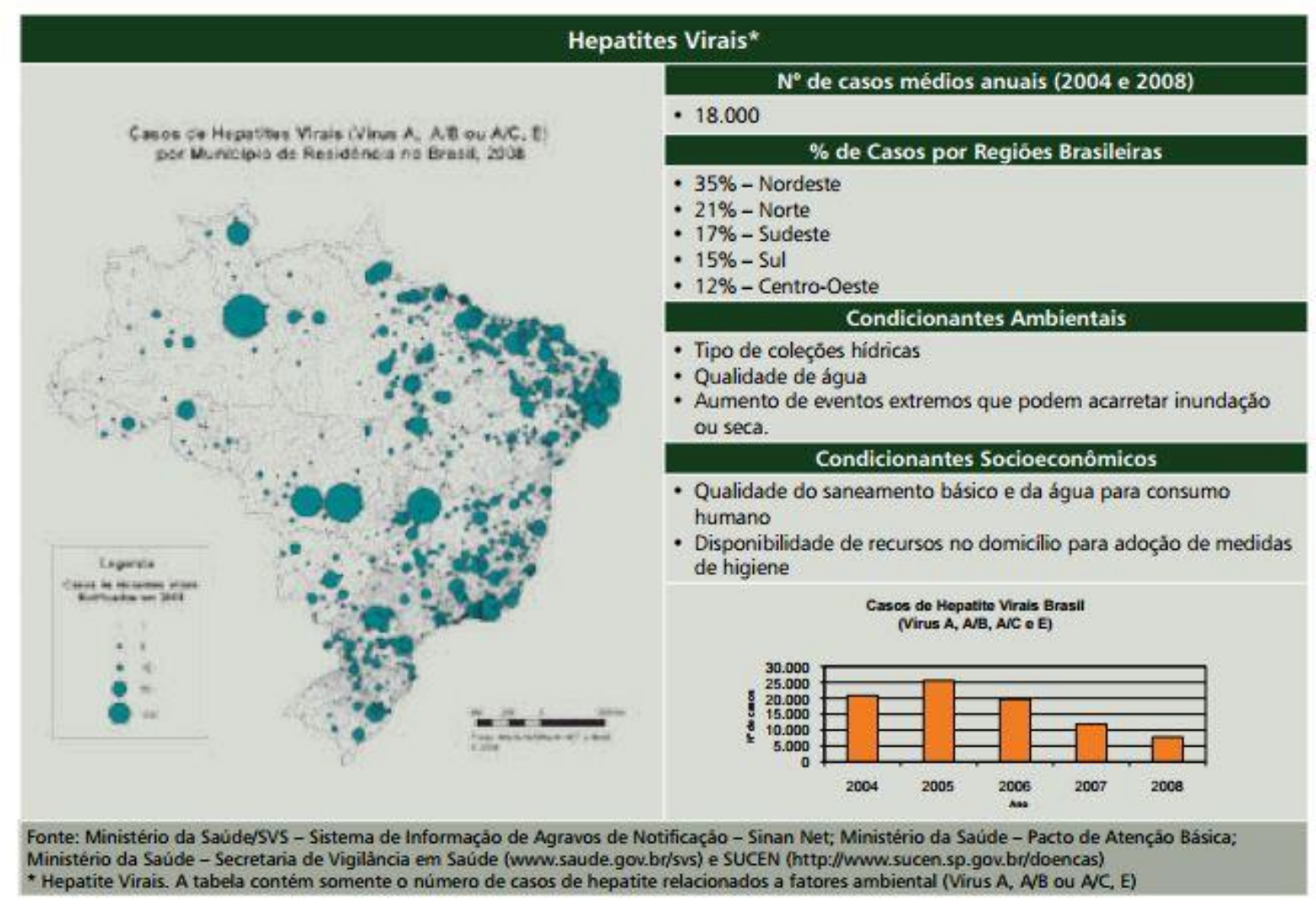

Figura 4 - Hepatites Virais no Brasil. Fonte: Ministério da Saúde.

A característica das cidades brasileiras corrobora para o surgimento de casos de Hepatite A: o constante fluxo de pessoas das zonas rurais para a periferia das grandes cidades e em condições de infraestrutura precária é fundamental para o entendimento da disseminação das doenças, pois o ambiente (CLEMENS et al. 2000).

Muitos relatos em diferentes países indicam que a influência da melhoria nas condições sanitárias de uma determinada população gera uma redução da prevalência da doença. O suprimento de água segura diminui a prevalência de hepatite A em longo prazo. Nesse contexto, a disponibilização de água tratada nos domicílios é uma medida eficaz de combate e controle da doença (FERREIRA; SILVEIRA, 2004).

Estudos realizados nas mais diversas regiões são importantes para identificar o padrão da distribuição espacial da incidência de Hepatite A, bem como revelar os fatores que influenciam no surgimento da enfermidade em um determinado recorte geográfico. Silva et al. (2007) analisaram na cidade do Rio de Janeiro os casos notificados da Hepatite A durante o período que compreende os anos de 1999 e 2001, subsidiados por dados dos setores 
censitários do Instituto Brasileiro de Geografia e Estatística - IBGE. Os resultados apontaram que o setor censitário com o maior número de domicílios com condições desfavoráveis oferece maior risco para o contágio da doença. A ausência de água encanada dificulta a higiene intra e peridomiciliar, o que aumenta a probabilidade de transmissão da doença.

Os usos das ferramentas de geoprocessamento são importantes para a análise integrada da incidência dos agravos. Basso \& Righi (2015) realizaram a espacialização dos casos de Hepatite A por meio do Sistema de Informação dos Agravos de Notificação (SINAN) no município de Porto Alegre entre 2007 e 2008. O resultado da pesquisa revelou que a maior incidência dos agravos ocorreu em áreas passíveis de inundação no bairro Archipélago.

As diferenças geográficas, climáticas, econômicas e de origem étnica da população são evidentes no Brasil, e isso interfere na epidemiologia das doenças segundo Clemens et al (2000). De acordo com os autores, um estudo realizado em quatro regiões do país (Norte, Nordeste, Sudeste e Sul) indicou e confirmou a importância da heterogeneidade da população na distribuição deste agravo. Observou-se a mudança na soroprevalência do HVA para endemicidade intermediária nas regiões nordeste, sudeste e sul. A região norte, ao contrário, mostrou alto padrão de endemicidade. $\mathrm{O}$ estudo revelou também a evidente diferença na soroprevalência de anticorpos anti-HVA conforme os níveis socioenconômicos.

Silva et al. (2007) analisaram a incidência de Hepatite A e Leptospirose no Rio de Janeiro entre os anos de 1999 e 2001 utilizando fontes secundárias de informação como os dados do SINAN e do Censo Demográfico de 2000, por meio da espacialização dos casos notificados, e, considerando, as variáveis socioambientais. Essas variáveis indicaram a presença de áreas de risco onde as notificações foram identificadas.

Estudo realizado por Tauil et al. (2009) identificou o surto de Hepatite A no município de Luziânia, região do entorno do Distrito Federal, no mês de junho de 2009, em decorrência do elevado aumento do número de casos naquele período. A investigação identificou a que a hipótese principal para essa incidência foi a ingestão de água contaminada, aliada à baixa condição socioeconômica, de saneamento básico e de condições higiênico-sanitárias.

A possibilidade de Hepatite A em locais de baixas condições socioeconômicas e sanitárias e em locais de risco é uma realidade para essa parcela da população. Soares (2013) realizou um trabalho de identificação de trabalhadores expostos a situações de risco. O estudo consistiu na análise de um grupo de catadores de Goiânia. A soroprevalência da infecção pelo HAV em catadores de materiais recicláveis na cidade goiana foi de 99,5\%, corroborando para 
a premissa de que a exposição a ambientes propícios aumenta o risco de surgimento da doença.

A literatura a respeito da Hepatite A mostra a grande variedade de situações e condições para a ocorrência dos casos do agravo, com diferentes configurações socioambientais. Entretanto, a condicionante econômica mostrou ser um dos principais fatores para notificação nas diversas áreas. Nos locais onde a infraestrutura é deficitária e a renda da população é baixa há maior vulnerabilidade para a exposição ao vírus HVA. 


\section{ASPECTOS AMBIENTAIS}

A componente ambiental é um fator relevante para a análise epidemiológica de agravos, pois a referência do meio em que uma população está inserida contribui para identificar as condições e propensões para a incidência de doenças diversas. Aspectos como a morfologia do terreno, fragmentação da paisagem, distribuição e alocação de infraestrutura de serviços de coleta de lixo e saneamento básico são alguns dos temas delineadores do contexto ambiental do terreno. Esses dados podem ser especializados e inseridos em modelos. Diante dessa situação, o uso de técnicas de modelagem em geoprocessamento se tornaram ferramentas multidisciplinares para a gestão territorial, pois permitem representar a morfologia do terreno e a representação de modelos (CÂMARA, 2002; SILVA, 2004).

\subsection{MODELO DIGITAL DO TERRENO}

Um Modelo Digital do Terreno (MDT), também conhecido como Digital Elevation Model pode ser definido como uma representação numérica ou digital de elevação do todo ou de parte da superfície terrestre, dada como uma função de localização geográfica (O’CALLAGHAN; MARK, 1984).

Os dados digitais de elevação são armazenados em um dos seguintes formatos: dados de ponto de elevação sobre uma grade regular ou uma rede integrada irregular, ou ainda contornos armazenados em um gráfico de linha digital. Cada formato oferece vantagens para aplicações, mas o formato em grade é mais comumente utilizado (ZHANG; MONTGOMERY, 1994).

De acordo com Schmidt \& Dikau (1999) a partir dos MDE's podem ser gerados outros dados derivados, relativos à parâmetros como declividade, orientação de vertente, aspecto do terreno, entre outros. Esses dados geomorfométricos são 
importantes para o entendimento da dinâmica do terreno, e também no auxílio à compreensão de diversos processos geológicos, geomorfológicos e hidrológicos.

A representação do relevo com base em sua fisiografia tem como premissa um princípio geomorfológico que é a de representar a FORMA do modelado terrestre. Indica, ainda, os parâmetros mais consistentes e de definição de uma padronização para a sua representação (NETO, 2015)

\subsubsection{Elaboração do MDT}

A metodologia aplicada para a elaboração do Modelo Digital de Terreno consiste na utilização de cartas topográficas do Sistema Cartográfico do Distrito Federal (SICAD), referentes à restituição do levantamento aerofotogramétrico feito pela Companhia Imobiliária de Brasília (TERRACAP) em 2009, do qual foi gerada a base de dados georreferenciada. O levantamento aerofotogramétrico gerou uma cartografia na escala 1:10.000, dividida em 244 folhas.

Foram utilizados três dados gerados pela restituição para a elaboração do MDT (Mapa 4): curvas de nível com equidistância de 5 metros, pontos cotados e hidrografia. Esses três arquivos foram obtidos da base do Sistema de Informação Territorial e Urbana do Distrito Federal - SITURB. A interpolação foi feita a partir da ferramenta Topo To Raster, da extensão Spatial Analyst no software ArcGIS Desktop 10. 


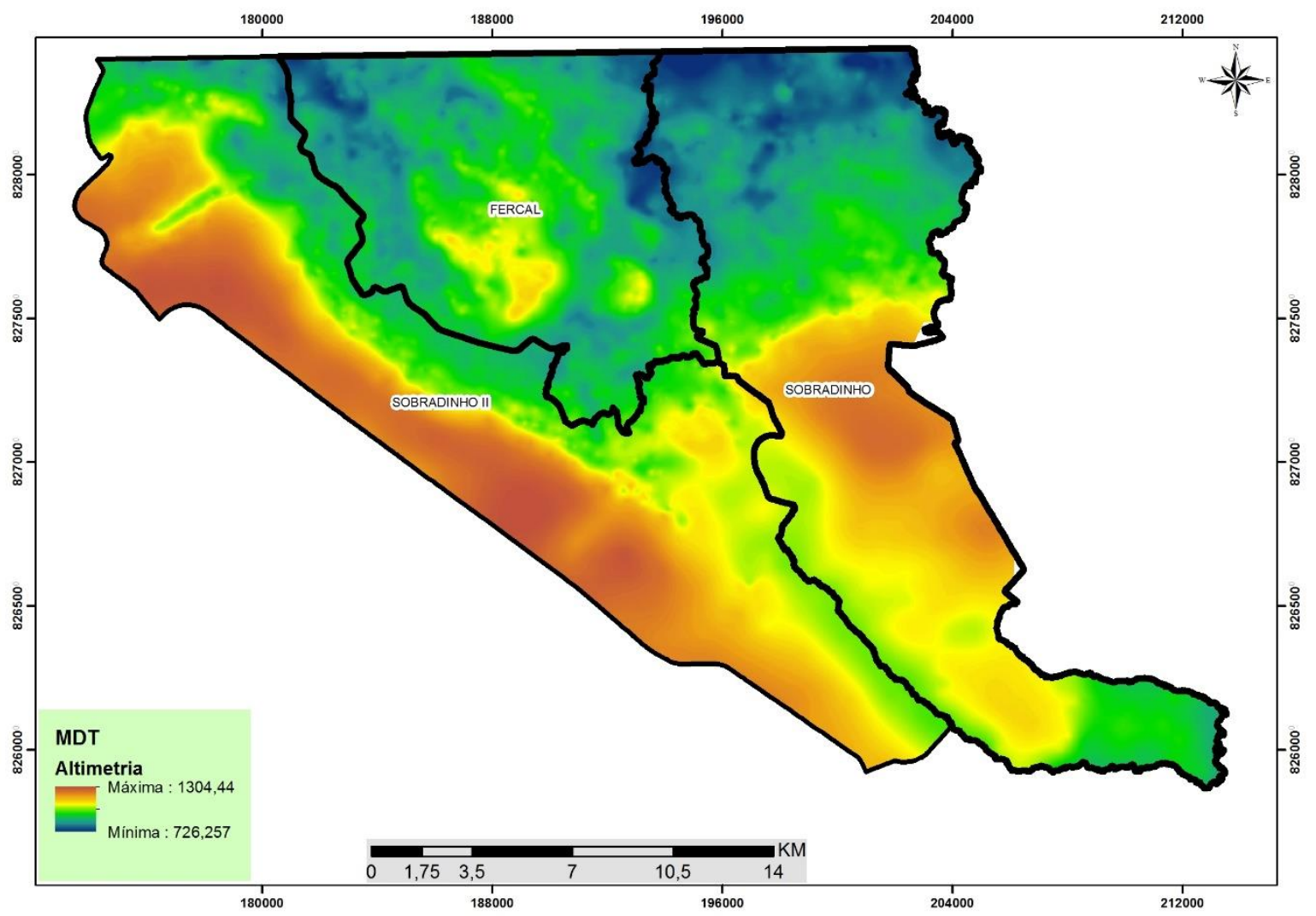

Mapa 4 - Modelo Digital de Terreno da área de estudo. Fonte: SITURB. Elaborado pelo autor.

A modelagem gerada representa a poligonal oficial da região administrativa de Sobradinho. Considerou-se um limite maior de extrapolação da poligonal para que não houvesse a interferência de dados, como, por exemplo, no limite norte da RA: como Sobradinho faz divisa com o município goiano de Planaltina de Goiás e não foram utilizadas informações desta região, optou-se por considerar apenas os dados existentes no Distrito Federal para a modelagem.

Após a elaboração do MDT, foi gerado o mapa de declividade por meio do módulo Spatial Analyst do ArcGIS 10 (Mapa 5). Ressalta-se que as maiores declividades são encontradas na porção norte da poligonal da RA de Sobradinho, onde o relevo é bastante movimentado. 


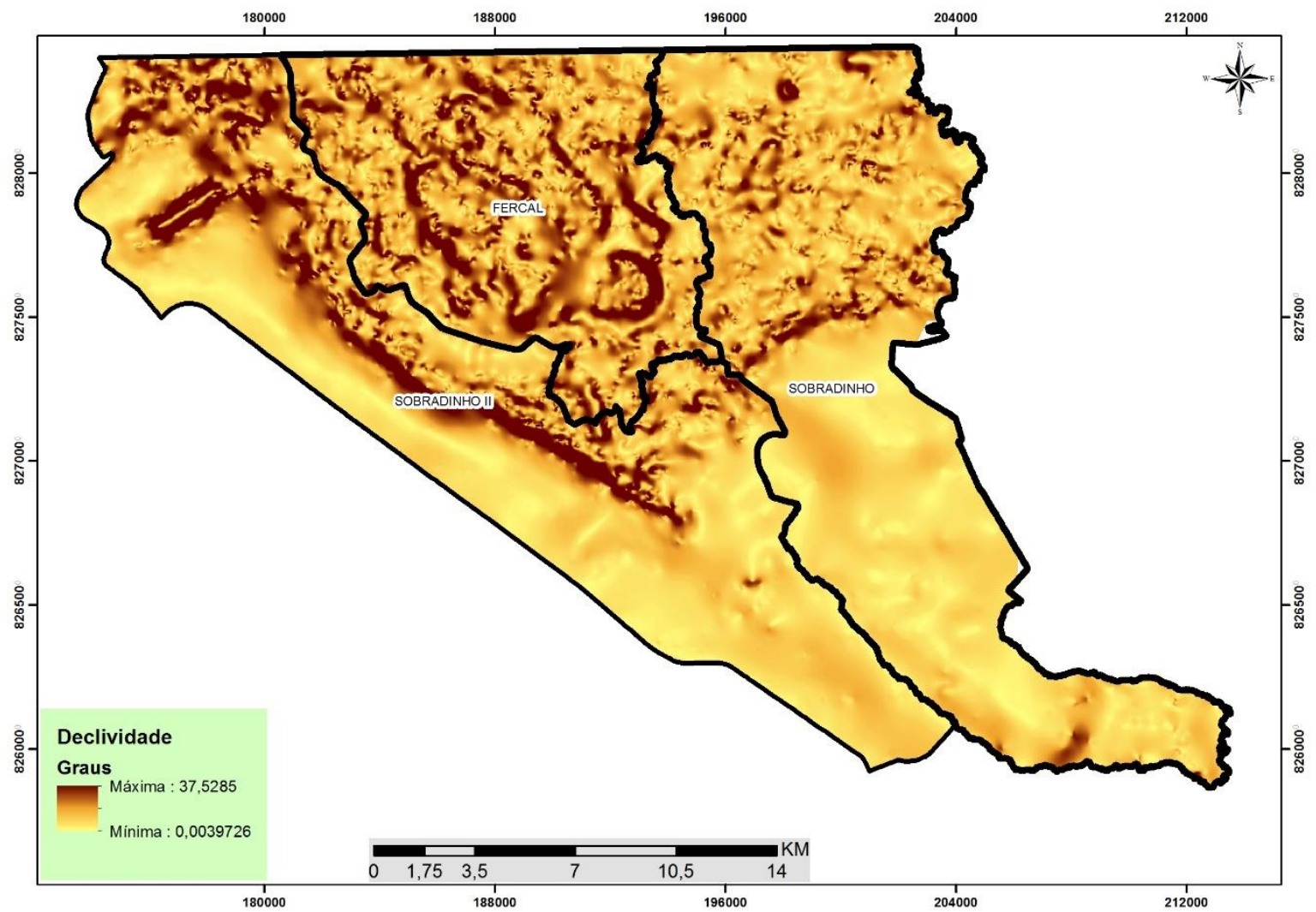

Mapa 5 - Declividade da área de estudo. Fonte: SITURB. Elaborado pelo autor.

\subsection{ASPECTOS SOCIAIS}

De acordo com os dados mais recentes da Pesquisa Distrital de Amostra por Domicílio - PDAD 2015, elaborado pela CODEPLAN, a população urbana de Sobradinho é de 68.551 habitantes. Sobradinho II tem aproximadamente 100.000 habitantes em sua zona urbana, e a Fercal, 8.746 habitantes em áreas urbanizadas.

O mesmo estudo revelou disparidades na renda mensal da população das três regiões administrativas: enquanto a renda domiciliar média mensal em Sobradinho e Sobradinho II apresentam valores próximos, a região da Fercal tem a menor média entre as áreas estudadas (Tabela 3). 
Tabela 3 - Renda domiciliar média nas áreas de estudo. Fonte: CODEPLAN, $(2013,2015)$

\begin{tabular}{lcc}
\hline $\begin{array}{c}\text { Renda Domiciliar Média Mensal } \\
\text { (Valores Absolutos) }\end{array}$ & $\mathbf{2 0 1 3}$ & $\mathbf{2 0 1 5}$ \\
\hline & & \\
SOBRADINHO & $\mathrm{R} \$ 5.461,51$ & $\mathrm{R} \$ 5.596,77$ \\
SOBRADINHO II & $\mathrm{R} \$ 5.520,14$ & $\mathrm{R} \$ 5.764,50$ \\
FERCAL & $\mathbf{R} \mathbf{2 . 0 9 7 , 6 2}$ & $\mathbf{R} \mathbf{2 . 2 9 4 , 0 0}$ \\
\hline
\end{tabular}

Tabela 4 - Renda per capita média mensal. Fonte: CODEPLAN, (2013,2015)

\begin{tabular}{|c|c|c|}
\hline Renda Per Capita Média Mensal & 2013 & 2015 \\
\hline SOBRADINHO & $R \$ 1.593,68$ & $\mathrm{R} \$ 1.775,79$ \\
\hline SOBRADINHO II & $\mathrm{R} \$ 1.518,41$ & $\mathrm{R} \$ 1.732,52$ \\
\hline FERCAL & $\mathrm{R} \$ 577,70$ & $\mathrm{R} \$ \mathbf{6 2 5 , 6 4}$ \\
\hline
\end{tabular}

Ressaltam-se os valores de renda mensal bem próximos entre Sobradinho e Sobradinho II, embora Sobradinho tenha tido um histórico de ocupação diverso de Sobradinho II enquanto a região da Fercal apresenta os mais baixos números de renda domiciliar média e renda per capita média mensal. Entretanto, um fato que pode auxiliar na análise desse cenário está na existência de um grande número de condomínios residenciais de melhor infraestrutura na RA de Sobradinho II, cujos moradores estão inseridos em uma faixa de renda maior.

Sobradinho, ao contrário, não dispõe de uma quantidade significativa de condomínios já consolidados e de alto padrão quando comparados à RA de Sobradinho II, pois esta contempla, por exemplo, a região do Setor Habitacional Grande Colorado, caracterizada por esse tipo de moradia. Em relação à Fercal, a região não dispõe de equipamentos urbanos e infraestrutura no mesmo nível daqueles incidentes nas outras duas RA's. A precariedade local é latente, tanto na falta de infraestrutura urbana básica da região como no acesso aos serviços de saúde. 
Essas particularidades são essenciais para subsidiar a discussão dos resultados da pesquisa, pois por meio delas é possível formular questionamentos para se verificar o contexto regional dos locais com notificação de Hepatite A.

\subsubsection{Lixo}

Os resíduos sólidos urbanos (RSU), comumente conhecidos como lixo representam uma preocupação ambiental em todo o mundo, em especial nos grandes centros urbanos dos países em desenvolvimento. A geração de RSU é proporcional ao crescimento da população e gera o aumento da demanda pela coleta pública. Caso não haja um tratamento adequado desses resíduos, pode-se afetar direta ou indiretamente a saúde, além de promover a degradação ambiental (RÊGO et al. 2002).

A questão da gestão do lixo é complexa, pois é comum nas cidades brasileiras a deposição inadequada de resíduos. O amontoamento desorganizado e desordenado de materiais sem utilidade muitas vezes é encontrado em terrenos baldios, margens de estradas, fundos de lagos e margens de lagos e rios. (MUCELIN; BELLINI, 2008). Ainda segundo os autores, essas práticas nocivas decorrentes do depósito de lixo em locais inapropriados podem, consequentemente, a contaminação de corpos d'água, enchentes, assoreamento, proliferação de vetores transmissores de doenças, entre outros.

A região de Sobradinho dispõe de sistema de regular de coleta de lixo durante a semana, sob gestão do Serviço de Limpeza Urbana (SLU). Esse serviço é realizado nas áreas urbanas de Sobradinho, Sobradinho II e Fercal.

Assim como na gestão dos serviços de saúde, o planejamento da gestão de resíduos sólidos não se limita à divisão política das regiões administrativas. No caso da área de estudo a atuação do SLU contempla Sobradinho, Sobradinho II e Fercal. Assim, há uma extrapolação quanto ao teórico limite das RA's, pois a atuação do serviço de limpeza considera a região como um todo e não apenas as divisões políticas das regiões administrativas.

Nota-se que o sistema de coleta é bem definido para as regiões administrativas de Sobradinho e Sobradinho II. Em relação à RA da Fercal, é informado apenas que a 
localidade é atendida pelo sistema de coleta de resíduos e não há maiores detalhamentos sobre a rota de coleta.

Mesmo com um sistema sólido para a coleta de lixo na área de estudo, vários focos de depósito irregular de resíduos puderam ser encontrados no local estudado com o subsídio da aerofotogrametria (mapa 6). Essa situação se assemelha com outros casos comuns de deposição em outras regiões do Brasil. Portanto, a identificação desses locais torna-se importante para a investigação de possíveis relações entre casos de Hepatite A e as áreas de concentração de resíduos.



Mapa 6 - Mapa dos focos de lixo. Fonte: SITURB. Elaborado pelo autor.

\subsubsection{Análise das áreas de risco em Sobradinho}

Um dos principais problemas da área de estudo refere-se à ocupação irregular no território. Em algumas localidades da região de Sobradinho há incidência de habitações irregulares em áreas de risco de deslizamento e desmoronamento.

Um estudo realizado em 2012 pela Defesa Civil do Distrito Federal indicou, por meio de mapeamento, várias áreas de risco na região da Vila Rabelo, região 
administrativa de Sobradinho II e na Fercal (Tabela 5). Um total de 421 residências foram identificadas de acordo com o grau de risco das áreas, sendo estas divididas em médio, alto e muito alto.

A Vila Rabelo apresenta um histórico de problemas na sua ordenação territorial. Há recorrentes casos de deslizamento de terra, devido ao local de instalação de moradias da população na região. O estudo da Defesa Civil identificou 209 locais de risco de deslizamento na Vila Rabelo I e Vila Rabelo II. No caso da Fercal, os riscos de desastres identificados foram deslizamento, enxurrada e alagamento em 421 pontos de risco. Nota-se que proporcionalmente a taxa de áreas de risco é muito relevante, por sua área ter uma abrangência muito menor que a região da Fercal.

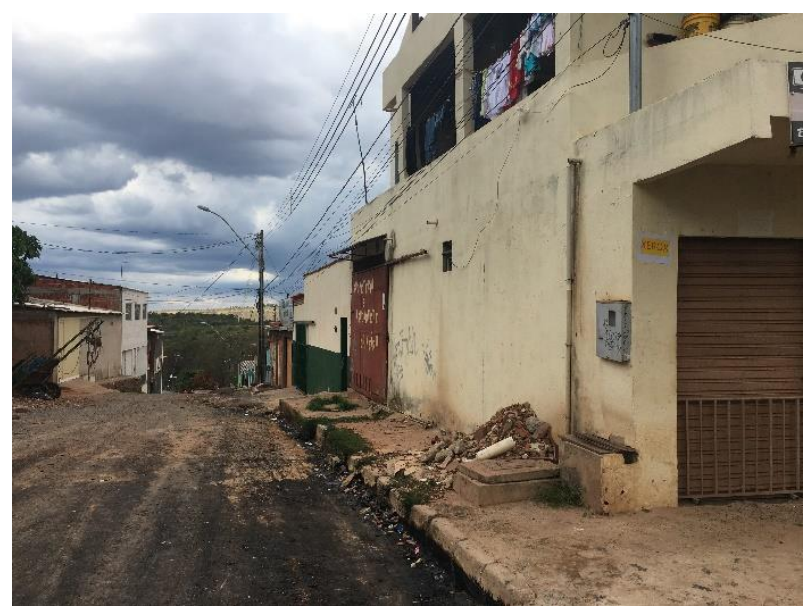

Figura 5 - Vila Rabelo próximo a áreas de risco. Fonte: elaboração do autor. 


\begin{tabular}{|c|c|c|c|c|c|}
\hline \multirow{2}{*}{$\begin{array}{l}\text { Área de } \\
\text { Risco }\end{array}$} & \multirow{2}{*}{ Risco(s) Prevalente(s) } & \multicolumn{3}{|c|}{ Grau de Risco } & \multirow[t]{2}{*}{ TOTAL } \\
\hline & & Muito Alto & Alto & Médio & \\
\hline $\begin{array}{c}\text { Vila } \\
\text { Rabelo I }\end{array}$ & Deslizamento & 93 & 39 & 18 & 150 \\
\hline $\begin{array}{c}\text { Vila } \\
\text { Rabelo II }\end{array}$ & Deslizamento & 53 & 16 & - & 69 \\
\hline Fercal & $\begin{array}{c}\text { Deslizamento, Enxurrada, } \\
\text { Alagamento }\end{array}$ & 185 & 173 & 63 & 421 \\
\hline
\end{tabular}

Tabela 5 - Áreas de risco em Sobradinho. Fonte: Defesa Civil/DF (2012).

Nota-se, portanto, as condições favoráveis para a incidência de agravos a partir da vulnerabilidade socioambiental em determinadas porções do território. Com o mapeamento dessas áreas torna-se imprescindível não só para representação das áreas de risco, mas para subsidiar ações a fim de mitigar ou minimizar os efeitos das moradias em áreas de risco. A identificação das principais áreas de risco é essencial para se inferir uma eventual correlação entre os locais de incidência de Hepatite $\mathrm{A}$ e as áreas de vulnerabilidade no território. 


\section{PERFIL EPIDEMIOLÓGICO DA HEPATITE A}

Os dados da incidência foram cedidos pela Diretoria de Vigilância Epidemiológica - DIVEP, da Secretaria de Estado de Saúde do Distrito Federal e foram extraídos do banco de dados do órgão. Esse banco alimenta informações para o Sistema de Informações de Notificação de Agravos à Saúde - SINAN, do Ministério da Saúde.

Primeiramente, o foco do estudo foi a espacialização do endereço dos notificados confirmados com a Hepatite A, de forma que esses dados georreferenciados pudessem ser relacionados com os aspectos socioambientais em um contexto de local.

De posse da data de notificação dos casos confirmados e do endereço de residência dos moradores, foi realizado o georreferenciamento dos todos os casos positivos para a HVA durante o período correspondente ao período de 2007 a 2015.

Foram desconsiderados e excluídos os dados que apresentavam inconsistência e incompletude, como por exemplo: falta de dados que possibilitassem a localização exata o endereço do notificado, como a ausência de conjunto e/ ou casa e campos em branco. Dessa forma, todas as informações que não apresentaram consistência e grau de confiabilidade para serem especializadas foram descartadas. Foram descartados 3 casos devido à impossibilidade de se localizar o endereço do notificado ou pela ausência dessa informação no banco de dados.

\subsection{AVALIAÇÃO DO BANCO DE DADOS}

O banco de dados epidemiológicos disponibilizado abrange todas as Hepatites virais. Considerando esta situação, foram selecionados os casos positivos e confirmados para a Hepatite A. Quanto à região da área de estudo, foram selecionados os casos registrados pelos centros de saúde locais: Centro de Saúde 01(CSS 01), Centro de Saúde 02(CSS 02), ambos em Sobradinho, e Centro de Saúde 03 (CSS 03), em Sobradinho II, e postos de saúde na região da Fercal. 
Considerando as características existentes na geração e manutenção do banco, foram desconsiderados os dados ignorados e/ou em branco no campo "Classificação Etiológica", além das informações inconclusivas no campo "Classificação Final"

Com a finalidade de se analisar somente os casos confirmados e gerar um grau maior de confiabilidade para o manejo dos dados, as notificações selecionadas se basearam na classificação etiológica do Vírus A e na confirmação laboratorial do mesmo. 


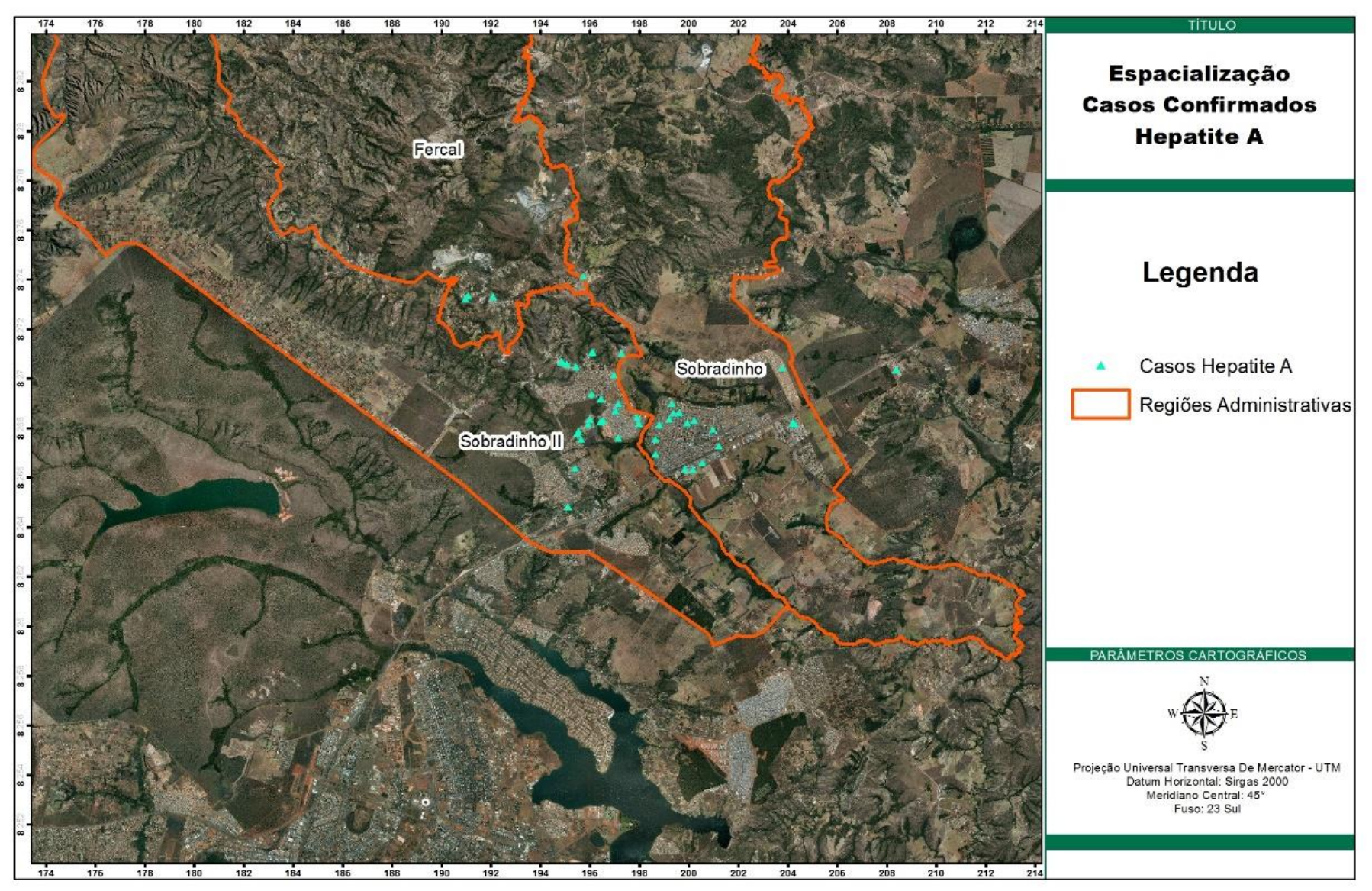

Mapa 7 - Espacialização dos casos confirmados de Hepatite A na região de Sobradinho. Fonte: DIVEP. 
A espacialização dos dados de casos notificados e confirmados de Hepatite A (mapa 7) indicaram uma tendência à incidência nas áreas urbanizadas de Sobradinho e Sobradinho II. Por meio da observação das fotografias áreas foram identificados poucos casos na Fercal, área preponderantemente rural. As notificações foram divididas por zonas: urbana, rural e periurbana, de acordo com a ficha de notificação de Hepatites do SINAN/Ministério da Saúde.

As áreas urbanas são presentes em 14 casos de 50, equivalente a $28 \%$ dos casos totais notificados. As zonas rurais comportam 6 casos (12\% dos casos). A maioria das notificações pertence a endereços localizados em zonas periurbanas, com $60 \%$ dos casos.

A maior parte dos casos notificados é relacionada aos locais de habitação consolidados e/ou em processo de consolidação, conforme análise visual da aerofotos. A existência de Hepatite A em áreas urbanizadas como Sobradinho e Sobradinho II pode estar relacionada a problemas ambientais, como por exemplo, o acúmulo de lixo e a falta de saneamento básico em torno das áreas mapeadas combinada com a concentração da população na região mais urbanizada da RA.

\subsection{DADOS EPIDEMIOLÓGICOS}

\subsubsection{Faixa etária}

Os dados da Secretaria de Saúde do Distrito Federal indicaram maior inclinação à ocorrência de Hepatite A entre a faixa de idade entre 6 e 10 com 19 ocorrências, correspondente a 39,58\% dos casos. A segunda faixa etária de maior ocorrência de Hepatite A refere-se às idades entre 11 e 15 anos, com 11 casos confirmados $(22,91 \%)$ do total. A média de idade dos notificados foi de 14,5 anos e o desvio padrão foi de 15,73. Em relação à mediana, o valor encontrado corresponde a 9. 
Essas taxas corroboram com os valores encontrados na literatura, onde a prevalência aos anticorpos anti-HVA é alta em crianças e adolescentes em famílias e baixa ou muito baixa renda (PEREIRA; FERREIRA, 2004).

Tabela 6 - Distribuição dos casos de Hepatite por idade. Fonte: SES/DF

\begin{tabular}{|c|c|c|}
\hline Faixa de Idade & Quantidade de Casos & Porcentagem \\
\hline $1-5$ ANOS & 7 & $14,58 \%$ \\
\hline $6-10$ ANOS & 19 & $39,58 \%$ \\
\hline $11-15$ ANOS & 11 & $22,91 \%$ \\
\hline $16-20$ ANOS & 5 & $10,41 \%$ \\
\hline $21-50$ ANOS & 3 & $6,25 \%$ \\
\hline ACIMA DE 50 ANOS & 3 & $\mathbf{1 0 0 \%}$ \\
\hline TOTAL & $\mathbf{4 8}$ & \\
\hline
\end{tabular}

\subsubsection{Institucionalização da doença}

A dificuldade em identificar as causas e os dados complementares à notificação da doença foi um fator encontrado durante a realização do trabalho. Cerca de $37 \%$ dos casos tiveram sua institucionalização ignorada e 33,33\% não foram institucionalizados. Assim, cerca de 70\% dos casos não foram institucionalizados (tabela 7). 
Essas informações são importantes para uma análise apurada para identificar a origem dos casos notificados. De acordo com Aguiar et al. (2009), há dificuldades em estabelecer diagnóstico em creches, orfanatos e áreas rurais, o que dificulta o reconhecimento do problema de saúde, devido à forma assintomática do agravo.

Tabela 7 - Notificação dos casos de Hepatite por institucionalização. Fonte: SES/DF.

\begin{tabular}{|c|c|c|}
\hline TIPO & QUANTIDADE & PERCENTAGEM \\
\hline EMPRESA & 1 & $2,08 \%$ \\
\hline ESCOLA & 12 & $25 \%$ \\
\hline IGNORADO & 18 & $37 \%$ \\
\hline NÃO INSTITUCIONALIZADO & 16 & $33,33 \%$ \\
\hline OUTRAS & 1 & 2,08 \\
\hline Total & $\mathbf{4 8}$ & $\mathbf{1 0 0} \%$ \\
\hline
\end{tabular}

\subsubsection{Fonte}

Como fonte de contaminação, o banco de dados da Secretaria de Saúde indicou um pouco além da metade dos casos oriundos por ingestão de água ou alimento. A fonte de infecção foi ignorada por $37,50 \%$ dos casos.

Tabela 8 - Casos de Hepatite por fonte. Fonte: SES/DF.

\begin{tabular}{|c|c|c|}
\hline FORMA & Quantidade de Casos & Porcentagem \\
\hline ÁGUA/ALIMENTO & 26 & $54,16 \%$ \\
\hline DOMICILIAR & 1 & $2,08 \%$ \\
\hline IGONORADO & 18 & $37,50 \%$ \\
\hline TRATAMENTO DENTÁRIO & 1 & $2,08 \%$ \\
\hline SEM INFORMAÇÃO & 2 & $4,16 \%$ \\
\hline
\end{tabular}




\subsection{MDT E OS CASOS DE HEPATITE A}

O Modelo Digital de Terreno (mapa 8) mostra a espacialização das notificações por endereço dos notificados em toda a área do estudo de casos entre Sobradinho é percebida uma variação altimétrica entre os dois núcleos urbanos principais, onde há concentração dos casos.

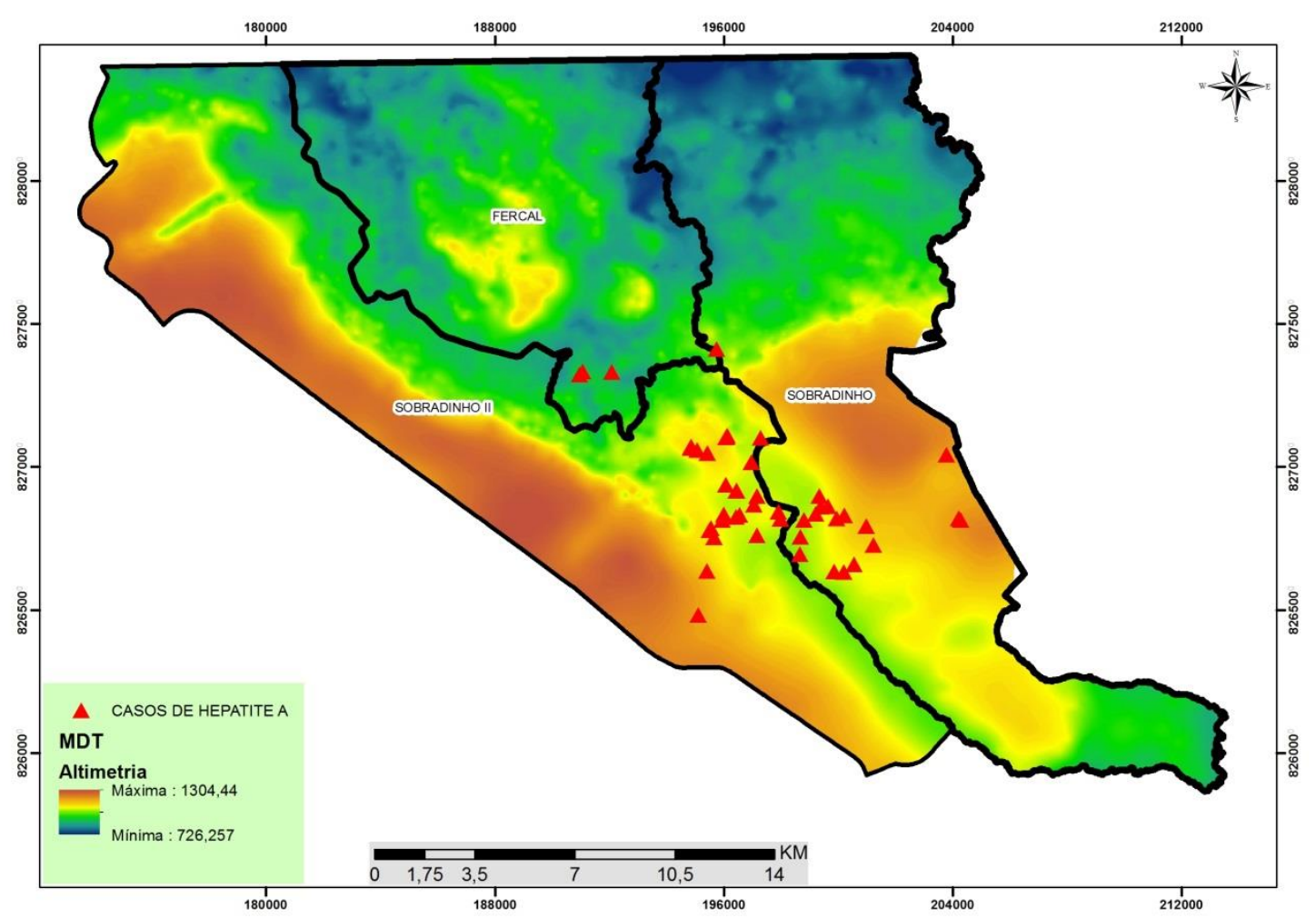

Mapa 8 - MDT com os casos confirmados de Hepatite A. Fonte: SITURB, elaborado pelo autor.

A região de Sobradinho é reconhecida por sua variação altimétrica decorrente de uma morfologia acentuada do terreno e a maioria dos casos concentra-se em áreas de média altitude, considerando os valores mínimos e máximos de altimetria da região (tabela 9). A concentração é eminente em áreas urbanas, com alguns casos isolados em áreas rurais. Portanto, a disposição das moradias é um fator essencial para compreender a alocação dos casos na área de estudo. 
Tabela 9 - Notificação dos casos a partir da altimetria. Fonte: SITURB; SES/DF.

\begin{tabular}{|c|c|}
\hline Altimetria (Metros) & Casos \\
\hline $900-950$ & 3 \\
\hline $1001-1050$ & 5 \\
\hline $1051-1100$ & 26 \\
\hline $1101-1150$ & 9 \\
\hline $1151-1200$ & 5 \\
\hline Total & $\mathbf{4 8}$ \\
\hline
\end{tabular}

\subsubsection{Declividade}

O Mapa de Declividade foi gerado a partir do MDT pela ferramenta Spatial Analyst do software ArcGIS Desktop (mapa 9). Optou-se por elaborar o mapa em porcentagens, de acordo com a classificação da EMBRAPA (1979). A predominância dos casos ocorreu em ambientes de relevo suave-ondulado (66,6\% dos casos), seguido de revelo plano $(25 \%)$ e ondulado $(8,33 \%)$.

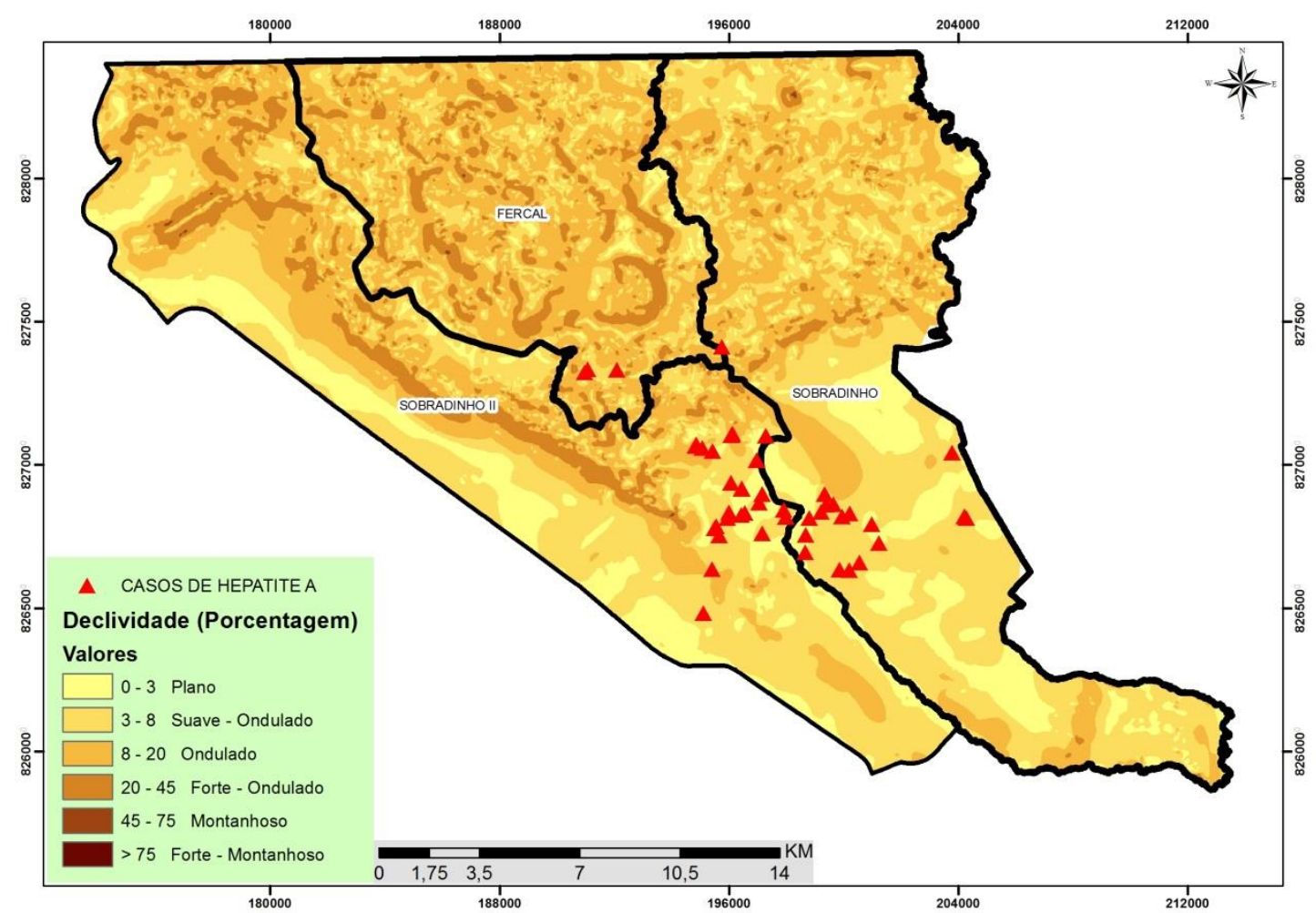

Mapa 9 - Declividade e os casos confirmados de Hepatite A. Fonte: SITURB;SES/DF, elaboração do autor. 
A série temporal dos casos de Hepatite A por meio georreferenciamento do endereço notificado apresenta a confirmação de Hepatite A entre os anos de 2007 e 2015. O maior número de casos notificados de Hepatite A ocorreu entre os anos de 2008 e 2009. Esse aumento no número de casos em relação ao último ano corrobora com os estudos de Tauil et al. (2009), que revelaram um grande aumento de notificações do agravo no município de Luziânia, região do entorno do Distrito Federal.

Notem-se com destaque os casos da região de Sobradinho II conhecida como Vila Rabelo, local já conhecido por seus problemas de habitação em áreas de eminente risco de desabamento (GDF, 2012).

\subsection{ANÁLISE TEMPORAL}

Embora a incidência do agravo seja espalhada e variada ao longo do limite das RA durante o período de estudo, a maior parte dos casos ocorreu em áreas de consolidação mais novas e em locais de baixa altitude. Não houve notificação de casos nas quadras residenciais consolidadas de Sobradinho localizadas em altimetria mais elevada (Quadras 13 a 18). Porém, em áreas próximas a essas quadras, houve notificação de 3 casos em áreas de maior altimetria e em processo de consolidação urbana, como identificou-se no Setor Habitacional Nova Colina e no Setor Habitacional Alto da Boa Vista. 


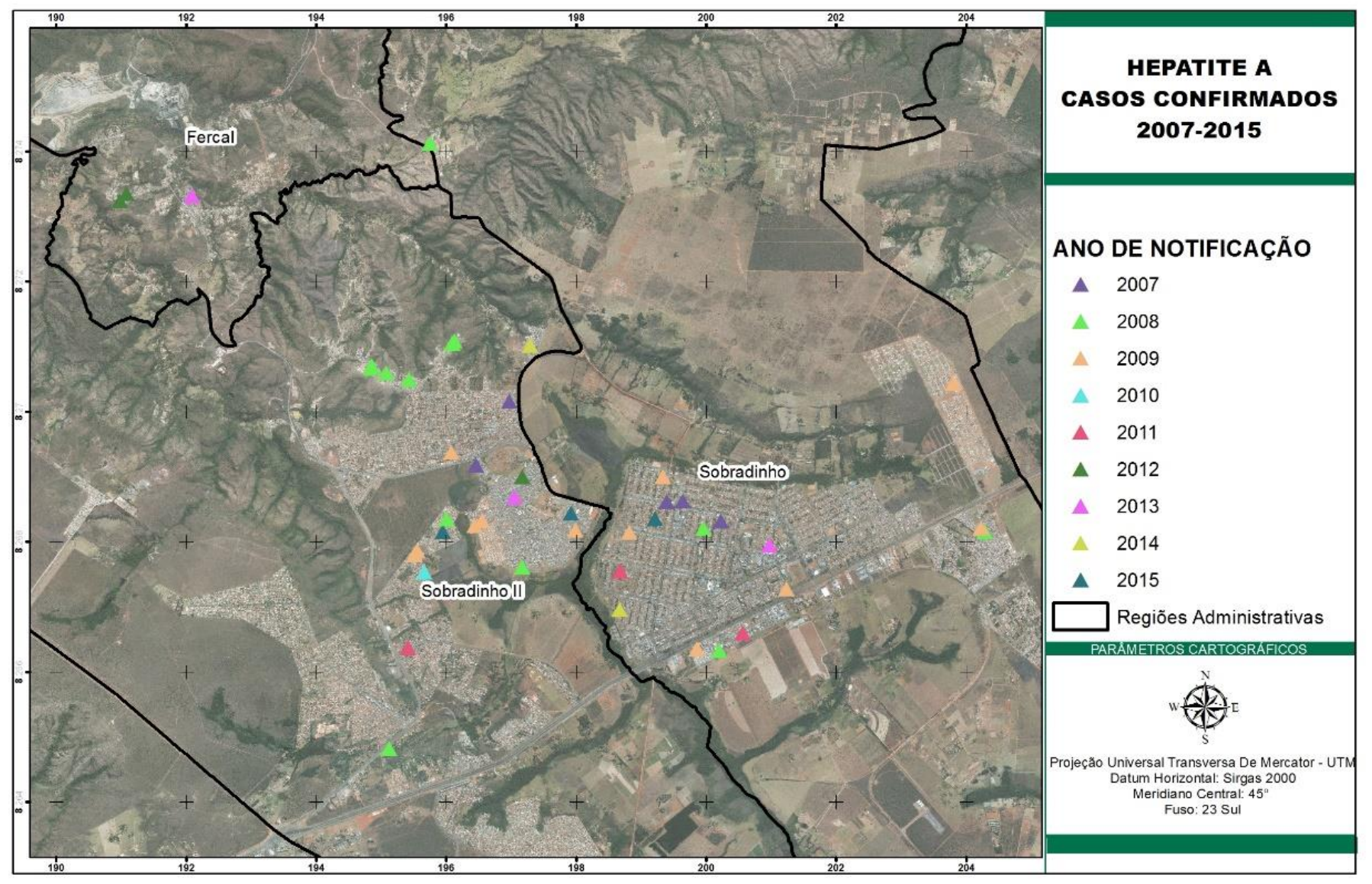

Mapa 10 - Espacialização temporal dos casos de hepatite A na RA de Sobradinho entre os anos de 2007 e 2015. Fonte: SES/DF, elaborado pelo autor. 
Foi confeccionado um mapa contendo buffers, ou raios, com distâncias de 30, 50 e 100 metros dos corpos hídricos e a espacialização das notificações de Hepatite com o intuito de ilustrar a relação entre o agravo e sua distância para os corpos d'agua da região (mapa 11). 


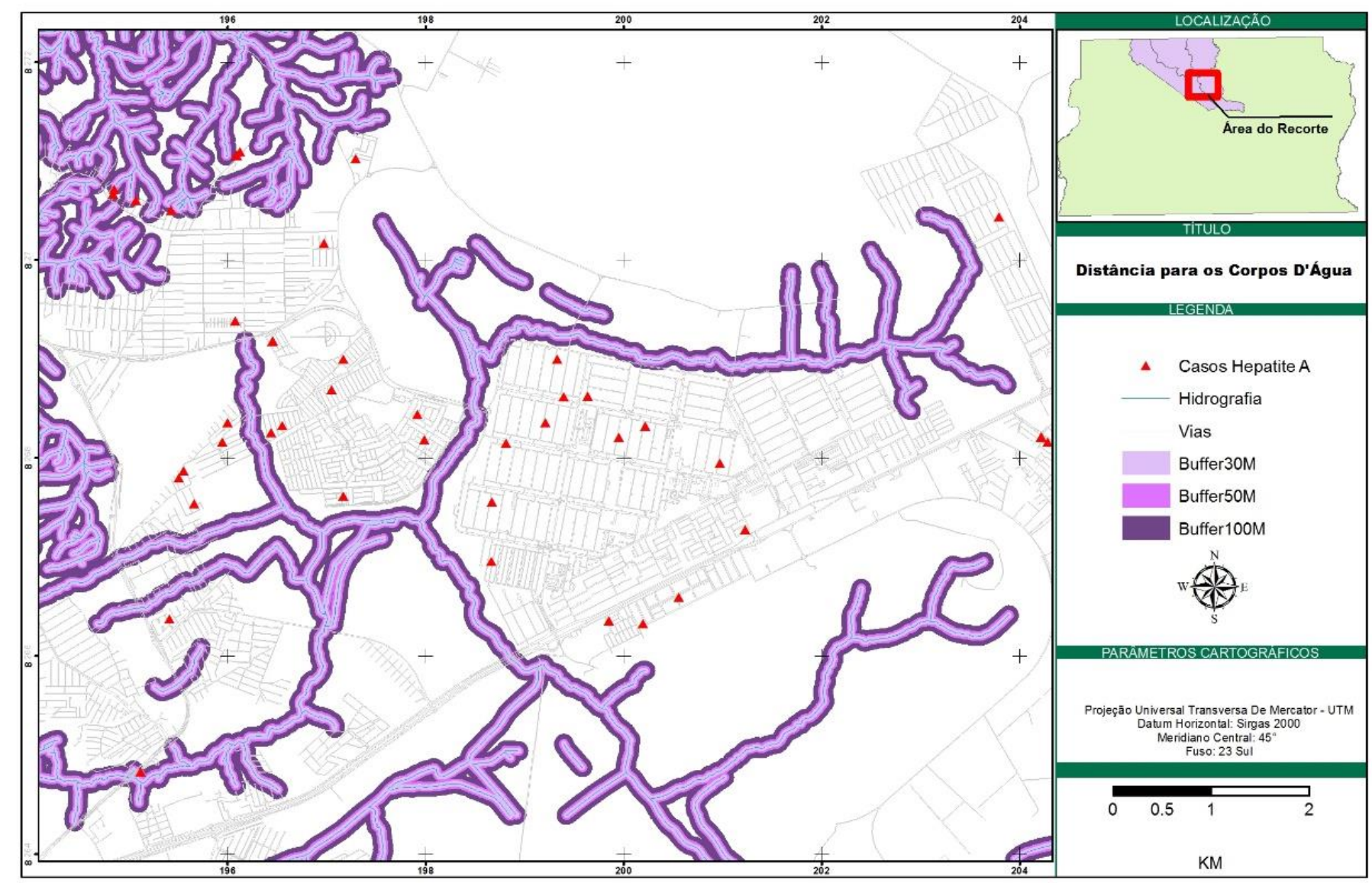

Mapa 11 - Corpos hídricos e os casos de hepatite A na RA de Sobradinho entre os anos de 2007 e 2015. Fonte: SITURB, elaborado pelo autor. 
Este mapa revela a distância entre os casos de Hepatite e a hidrografia: em apenas um caso o endereço do notificado está a menos de 50 metros de distância do corpo d'água mais próximo. Em 8 casos a distância entre as duas variáveis é de menos de 100 metros. Os outros 41 casos de Hepatite têm endereços com distâncias maiores de 100 metros do corpo hídrico mais próximo.

Os mapas 12 e 13 apresentam com maior detalhamento o padrão epidemiológico de hepatite A sobrepostos pelo MDT e (Mapa 12) e declividade (Mapa 13). A concentração de casos coincide com as áreas de maior adensamento populacional. E apesar da região norte da área de estudo ser caracterizada pelo relevo movimentado, é predominantemente rural e de baixa densidade populacional, o que reflete no número de casos de Hepatite A. 


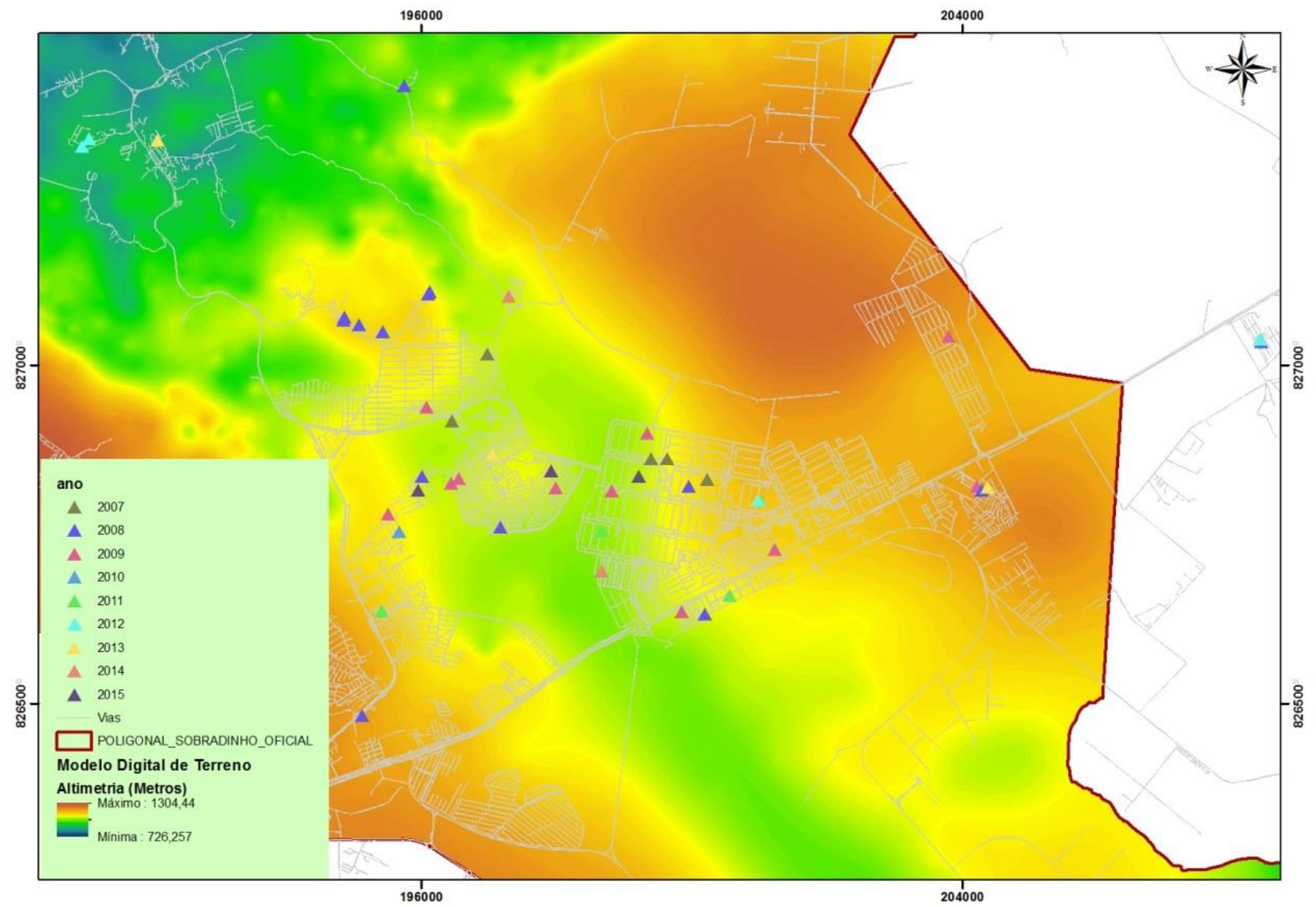

Mapa 12 - Detalhamento da espacialização temporal dos casos de Hepatite A e o MDT. Fonte: TERRACAP; SES/DF, elaborado pelo autor. 


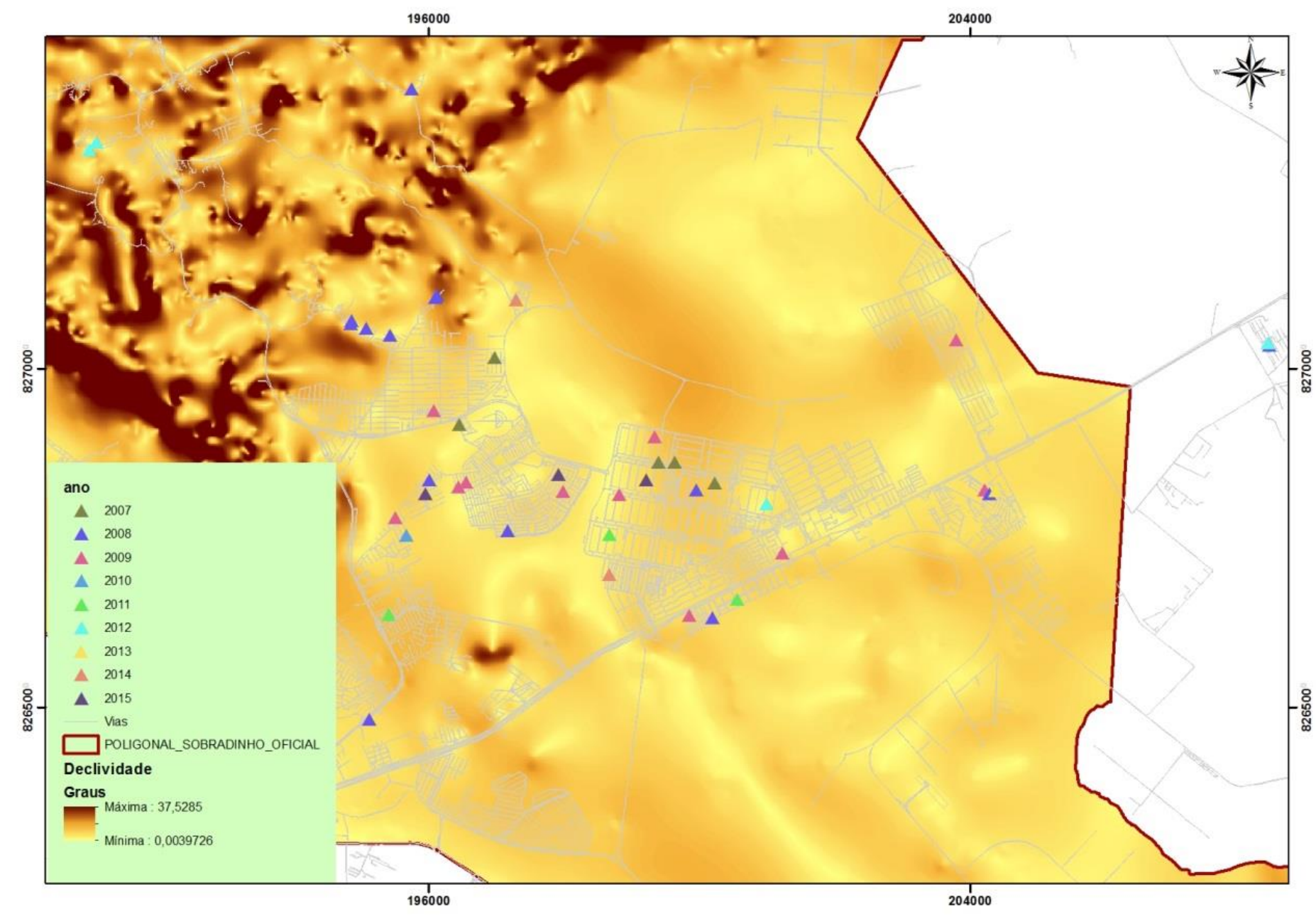

Mapa 13 - Detalhamento da espacialização temporal dos casos de Hepatite A e a declividade. Fonte: TERRACAP; SES/DF, elaborado pelo autor. 


\subsection{ESTIMADOR KERNEL}

Optou-se pela utilização do estimador Kernel para o presente estudo (mapa 14). Foi elaborado o Mapa de Kernel para o período histórico de casos confirmados entre de 2007 e 2015 na área de estudo por meio do módulo Spatial Analyst do software ArcGIS, com os dados interpolados em células de 20 metros. Foram instituídas 5 classes para melhor visualizar e diferenciar os hot spots das áreas de menor incidência. 


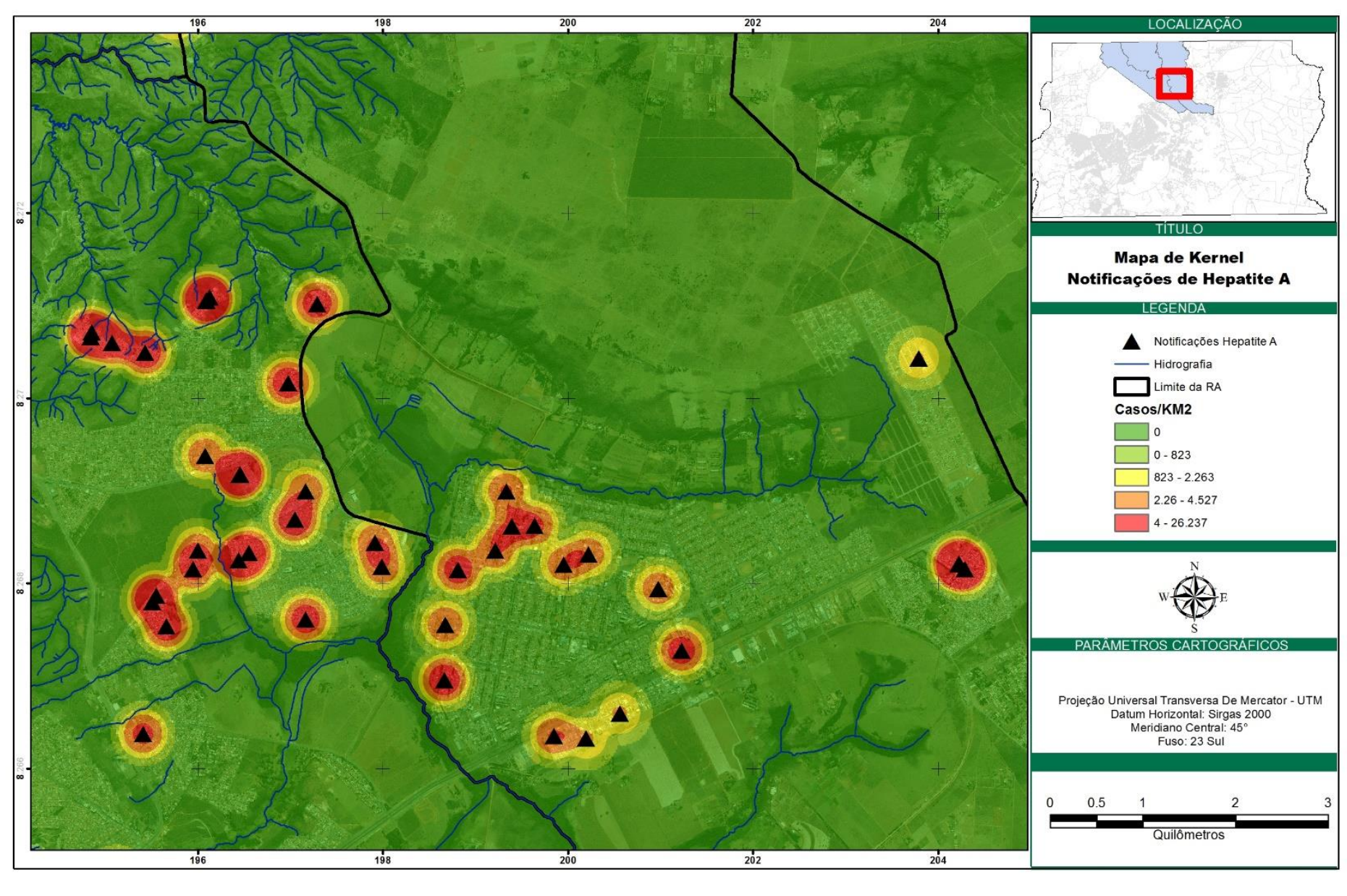

Mapa 14 - Densidade Kernel para os casos confirmados de Hepatite A. Fonte: SES/DF, elaborado pelo autor. 
O mapa indica três zonas principais de concentração dos casos nas regiões administrativas de Sobradinho, Sobradinho II e Fercal. A primeira e maior zona de concentração de casos concentra-se entre a Rodovia DF 150 e Sobradinho II, sendo integrante da poligonal desta localidade. A área é caracterizada por uma ocupação urbana mais recente, em geral, loteamentos irregulares de menor renda. De acordo com o Plano Diretor de Ordenamento Territorial do Distrito Federal - PDOT, instituído pela Lei Complementar $n^{\circ}$ 854, de 10 de outubro de $2012^{2}$ a região está inserida nas Áreas de Regularização de Interesse Específico - ARINE Contagem I e Área de Regularização de Interesse Social - ARIS Buritis.

A segunda zona de maior concentração localiza-se no Setor de Mansões de Sobradinho. Esta região é se caracteriza pela presença de condomínios e áreas de risco em seu entorno. Sob o limite norte encontram-se as áreas de maiores riscos ambientais da região. A região nas proximidades de Vila Rabelo é bastante susceptível a problemas ambientais (mapa 14), pois a ocupação desordenada gerou e gera riscos à região, como o desabamento e riscos de erosão.

A terceira zona está presente nas quadras residenciais de Sobradinho, onde a concentração está principalmente nas quadras ímpares, região de menor altimetria e mais próxima a Sobradinho II.

Na região administrativa da Fercal houve casos isolados, em comunidades rurais afastadas (Lobeiral) e áreas de maior consolidação urbana (comunidades Engenho Velho e Expansão Alto Bela Vista).

\footnotetext{
${ }^{2}$ A Lei Complementar no 854 de 15 de outubro de 2012 apresenta dispositivos que atualizam a LC no $803 / 2009$
} 


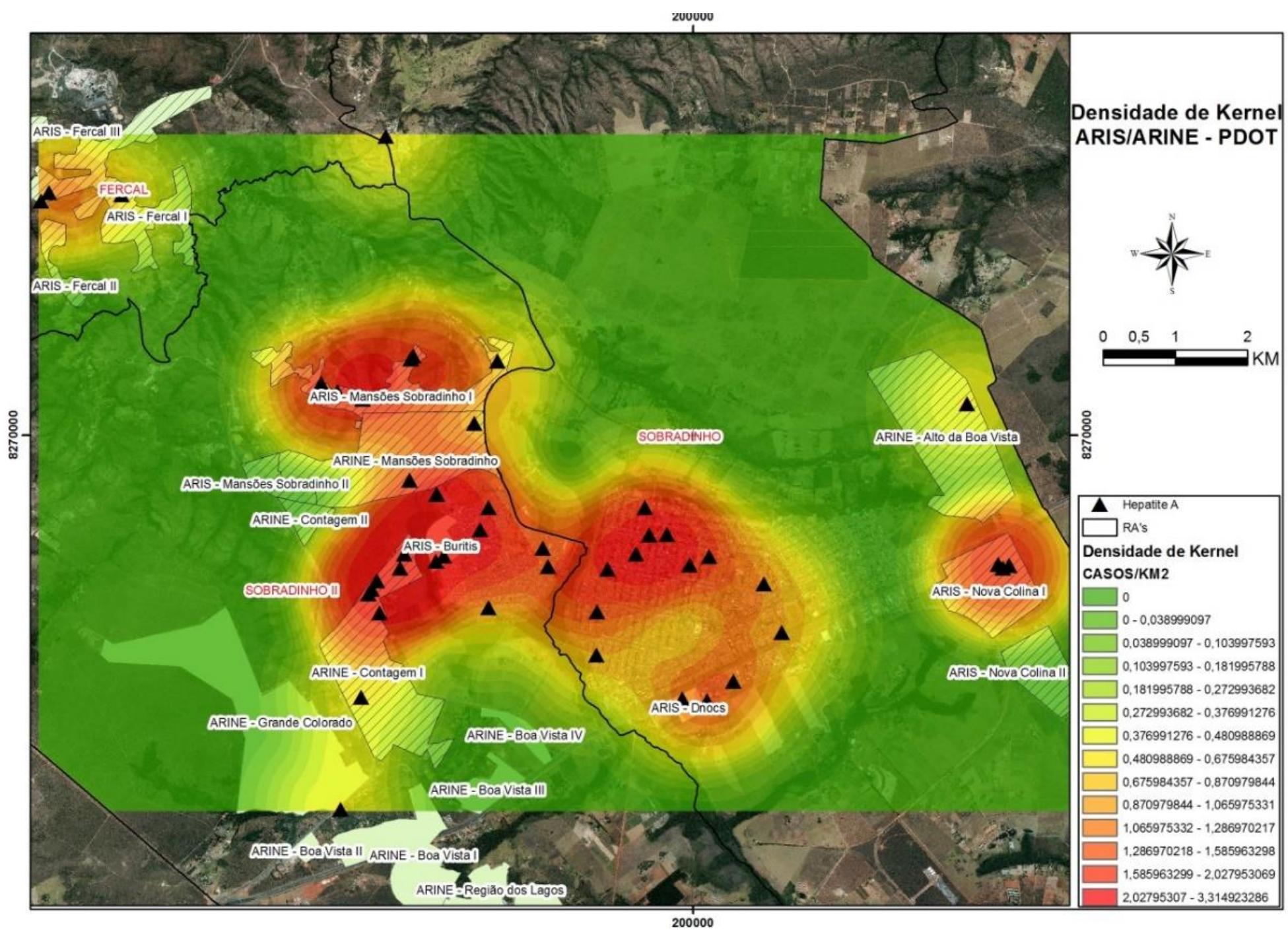

Mapa 15 - Mapa de Kernel junto aos setores censitários. Fonte: SEGETH; SES/DF, elaborado pelo autor. 


\section{PERFIL EPIDEMIOLÓGICO E AS VARIÁVEIS AMBIENTAIS}

\subsection{MAPEAMENTO DOS FOCOS DE LIXO}

Esta etapa consistiu no processo de mapeamento das áreas de foco de depósito de lixo na região administrativa de Sobradinho. O objetivo do trabalho é verificar os focos de lixo na região de estudo a fim de dar subsídios à análise ambiental da região de Sobradinho e sua vinculação ou não com a incidência de casos de Hepatite A.

Por meio de uma análise visual com uso de imagens aerofotogramétricas da TERRACAP com resolução espacial de 1 metro e 0,23 centímetros, foram gerados arquivos denominados "Focos de Lixo" subsidiados pelo levantamento aéreo nos anos de 2009, 2013, 2014 e 2015. Para cada ano foi gerado um arquivo shapefile contendo arquivos vetoriais em formato de polígonos para os respectivos anos. Foram identificados os seguintes focos de lixo e a respectiva área total por metro quadrado (tabela 10).

Tabela 10 - Focos de lixo. Fonte: elaboração do autor.

\begin{tabular}{|c|c|c|}
\hline ANO & $\begin{array}{c}\text { NÚMERO DE FOCOS DE } \\
\text { LIXO }\end{array}$ & ÁREA(m $\left.{ }^{2}\right)$ \\
\hline 2009 & 73 & 16017 \\
\hline 2013 & 83 & 11115 \\
\hline 2014 & 97 & 22552 \\
\hline 2015 & 69 & 14608 \\
\hline
\end{tabular}

O mapeamento dos focos de lixo foi importante para se fazer uma análise ambiental da área de estudo, visto que a Hepatite é uma doença que é relacionada a água 
e o contexto do meio ambiente subsidia esse diagnóstico. A relação entre os focos de lixo e os locais notificados com o vírus HVA não é diretamente interligada. A menor distância entre essas duas variáveis foi de 81 metros, e a maior, 5976 metros. Ou seja, pode-se ter uma distância considerável entre a residência do notificado e o foco de lixo. Entretanto, esse mapeamento faz-se necessário para a caracterização do meio habitado pelos moradores da região. Esse mapeamento revelou a predominância de depósito irregular de lixo áreas periféricas e limítrofes das zonas urbanas.

O mapa 16 é um exemplo do mapeamento em uma das áreas mais representativas quanto ao foco de depósito irregular de resíduos da região, próxima ao Ribeirão Sobradinho, entre Sobradinho e Sobradinho II, e também próximo às matas de galeria.

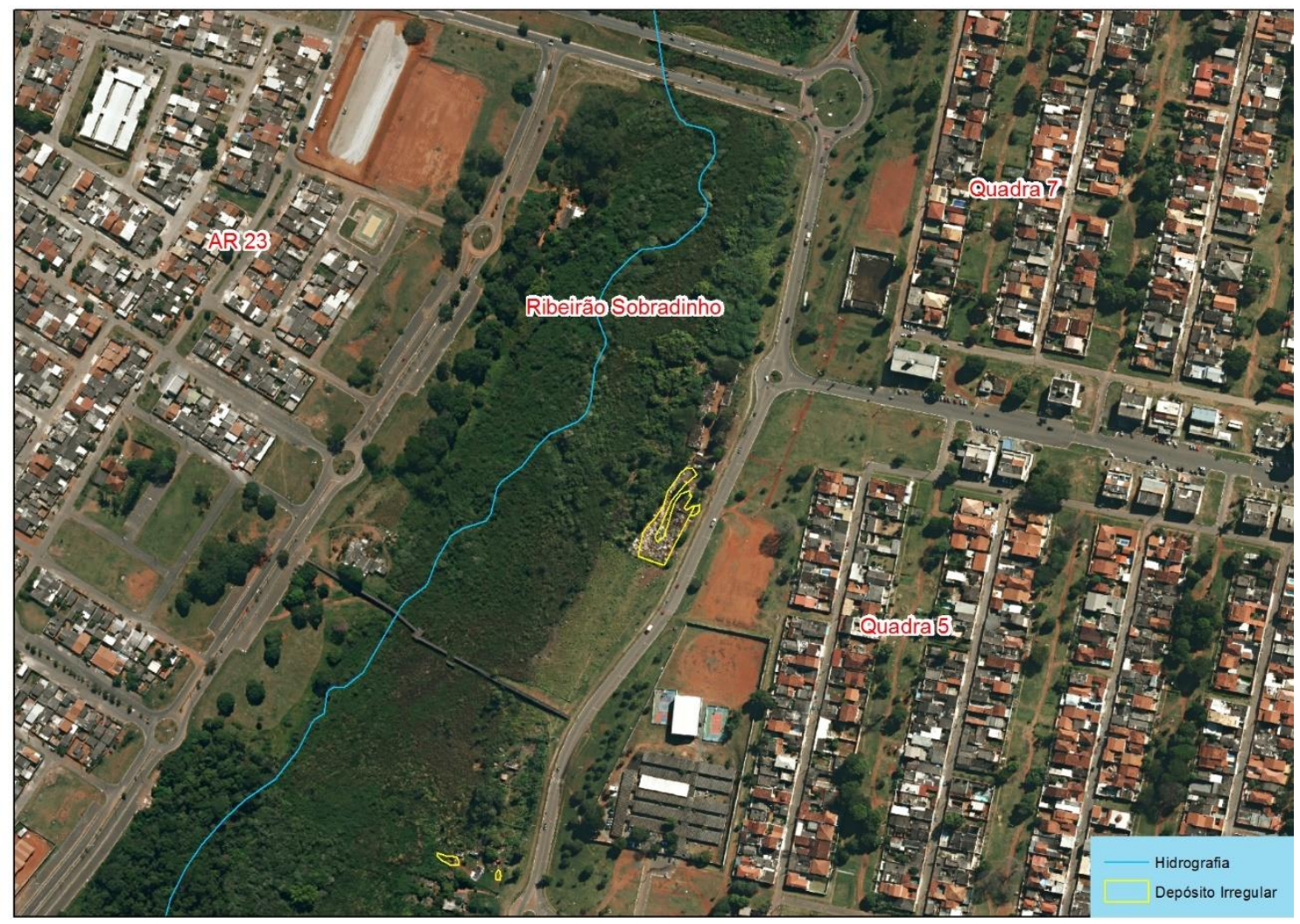

Mapa 16 - Ribeirão Sobradinho e um dos focos de lixo. Elaboração do autor.

O corpo hídrico não é utilizado para consumo, mas já teve sua função relacionada ao lazer dos moradores locais.Porém, ao longo dos anos o rio foi se tornando depósito de lixo pelos moradores (ZORZINI et al., 2011). Além disso, o 
ribeirão Sobradinho é classificado como corpo receptor de esgotos domésticos (GDF, 2012).

A fim de relacionar os casos de notificação de Hepatite A e os focos de lixo na área de estudo, foi elaborado uma Mapa de Densidade Kernel com os dados de focos de lixo, cuja finalidade é verificar o comportamento espacial da disposição dos resíduos sólidos em áreas na região de Sobradinho e os casos de Hepatite A.

O Mapa de Densidade Kernel foi elaborado no software ArcGIS 10.4.1 com uma célula de 4 metros e a distância medida em quilômetros quadrados. Os dados de entrada correspondem à espacialização dos focos de lixo, por meio de análise visual nos anos de 2009, 2013, 2014 e 2015. A decisão de escolha dos anos ocorreu devido à disponibilidade de fotografias aerofogramétricas de altíssima resolução do Distro Federal disponíveis sem custos adicionais de aquisição (mapa 17). 


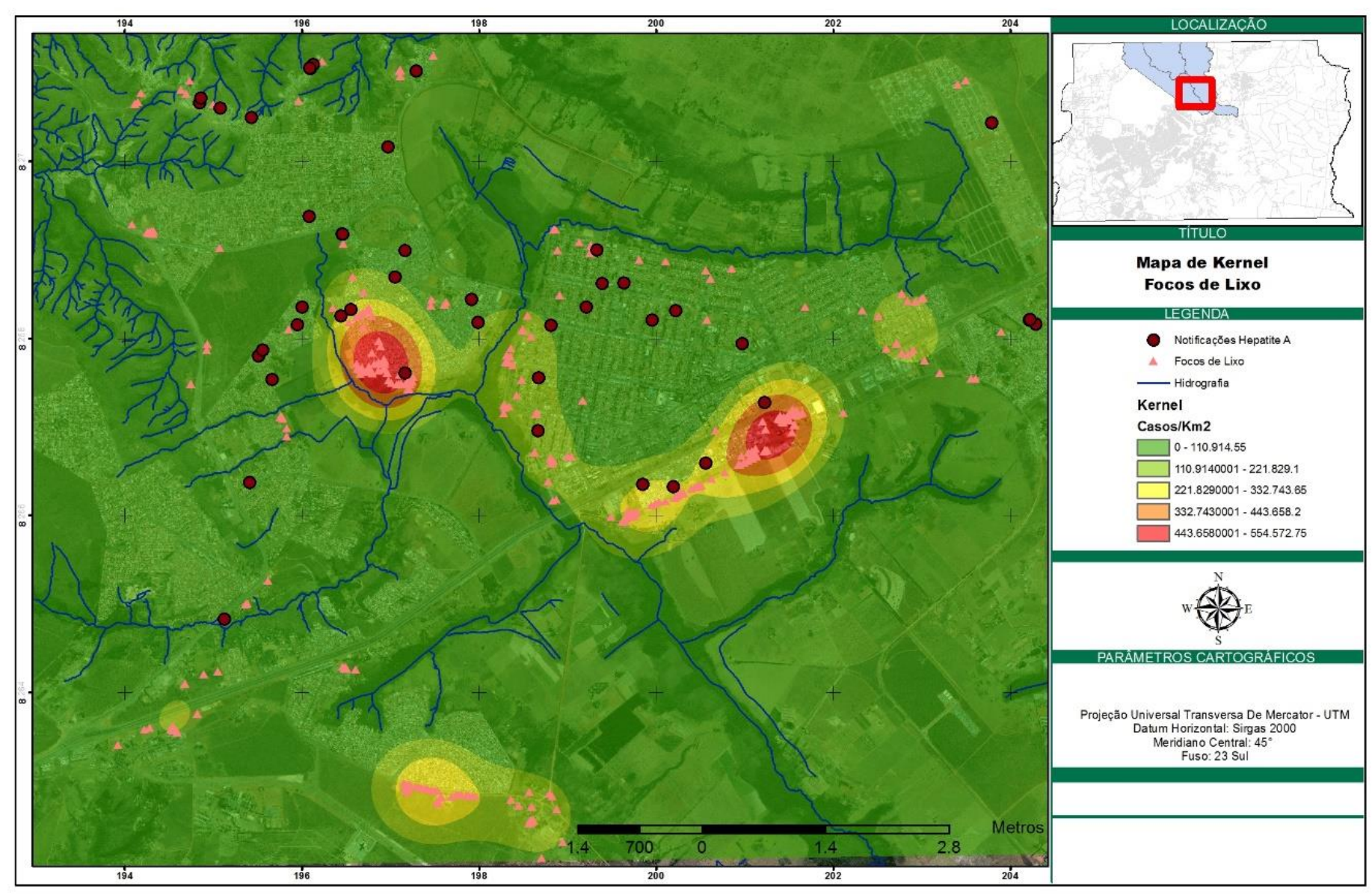

Mapa 17 - Densidade Kernel dos focos de lixo. Fonte: elaboração do autor. 
O mapa de densidade indica duas áreas de maior concentração. Uma à esquerda, nas bordas das quadras mais recentes de Sobradinho II e a outra próxima à vila DNOCS e Setor de Expansão Econômica de Sobradinho, próximo às margens da rodovia BR 020. Uma área de menor intensidade, próxima aos condomínios Império dos Nobres e RK apresenta importantes focos de lixo, porém sem casos de Hepatite A. Observa-se, também, uma quantidade de focos de lixo próximos ao Ribeirão Sobradinho. Isso corrobora com a situação de degradação ambiental naquela região.

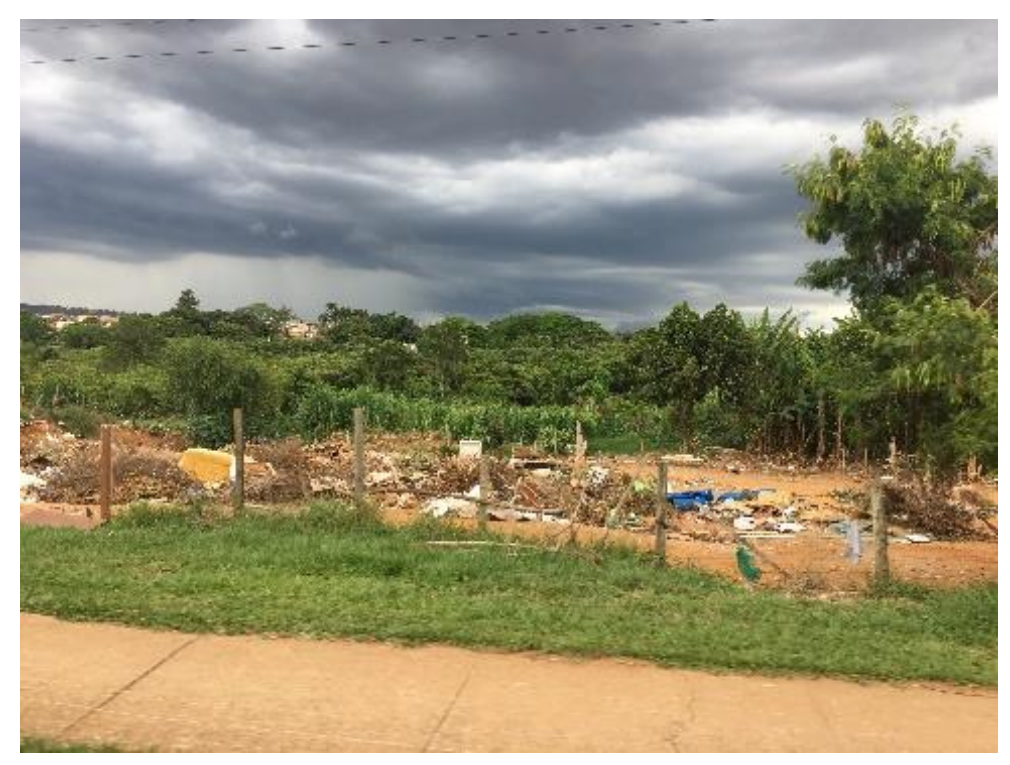

Figura 6 - Depósito de resíduos próximo à mata de galeria do Ribeirão Sobradinho, entre Sobradinho e Sobradinho II. Fonte: elaboração do autor. 


\subsection{ASPECTOS CLIMATICOS}

O regime pluviométrico de Brasília apresenta a característica de ter dois períodos bem definidos. Um período chuvoso, que contempla os meses de outubro a abril atingindo valores que variam de 132 a $243 \mathrm{~mm}$ e outro seco, de maio a setembro. No período seco, os números totais de chuvas não ultrapassam os $50 \mathrm{~mm}$, e em grande parte desse período os totais mantém-se abaixo de $15 \mathrm{~mm}$ e número de dias de chuvas inferiores a 5 (ALMEIDA; OLIVEIRA, 2013).

Com o intuito de correlacionar os casos de exposição ao VHA e fatores ambientais, buscou-se verificar o padrão da distribuição pluviométrica ao longo do período de estudo. Utilizaram-se dados da estação meteorológica do Instituto Nacional de Meteorologia - INMET, pois por meio desse instituto foi possível agrupar mensalmente os índices pluviométricos entre 2007 e 2015. Apesar da existência de uma estação pluviométrica na região de Sobradinho na ETA Sobradinho, não houve possibilidade de utilização dos dados dessa estação, pois o período histórico de atividade não contemplou o recorte temporal da pesquisa. Os gráficos abaixo indicam o regime pluviométrico de Brasília entre os anos de 2007 e 2015.

Chuva Acumulada Mensal X Chuva (Normal Climatológica 61-90)

BRASILIA (DF) - Para o Ano: 2007

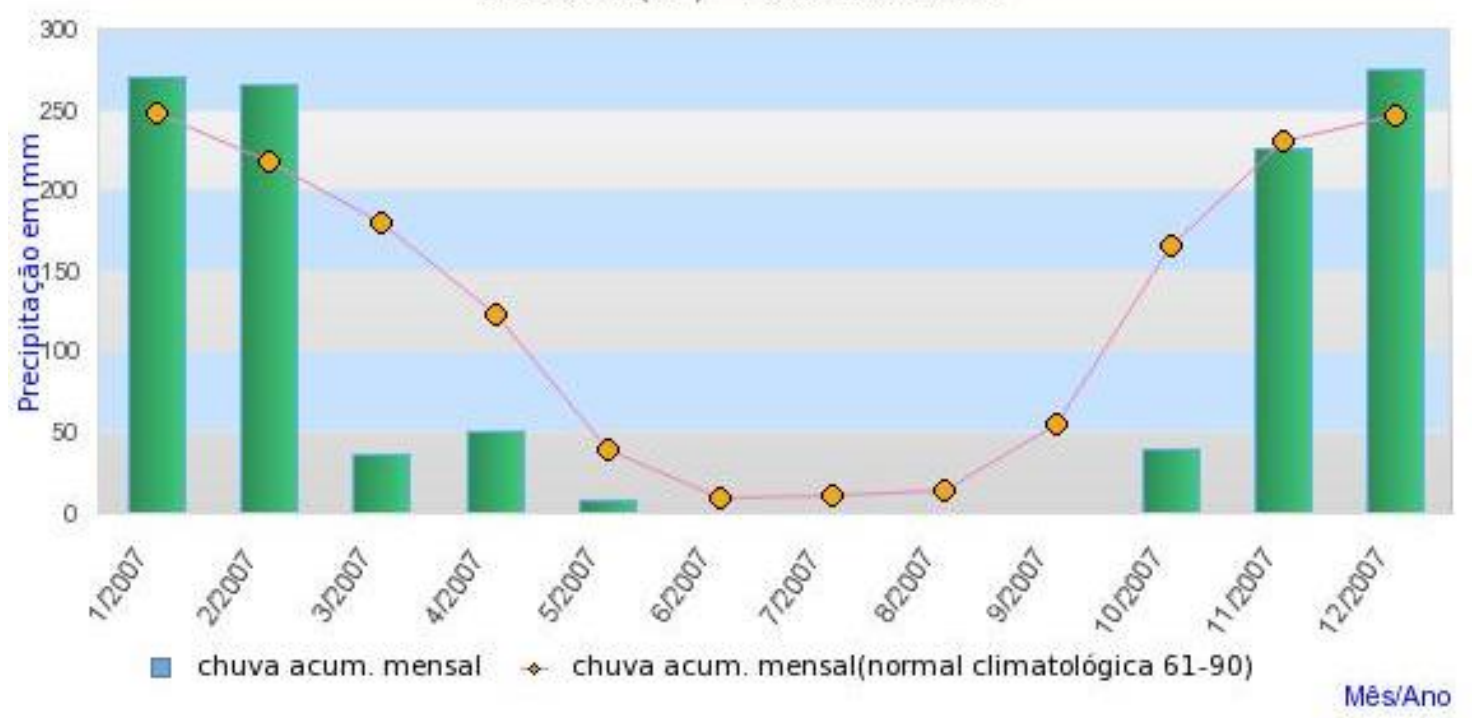

Gráfico 1 - Regime pluviométrico em 2007. Fonte: INMET 
Chuva Acumulada Mensal X Chuva (Normal Climatológica 61-90)

BRASILIA (DF) - Para o Ano: 2008

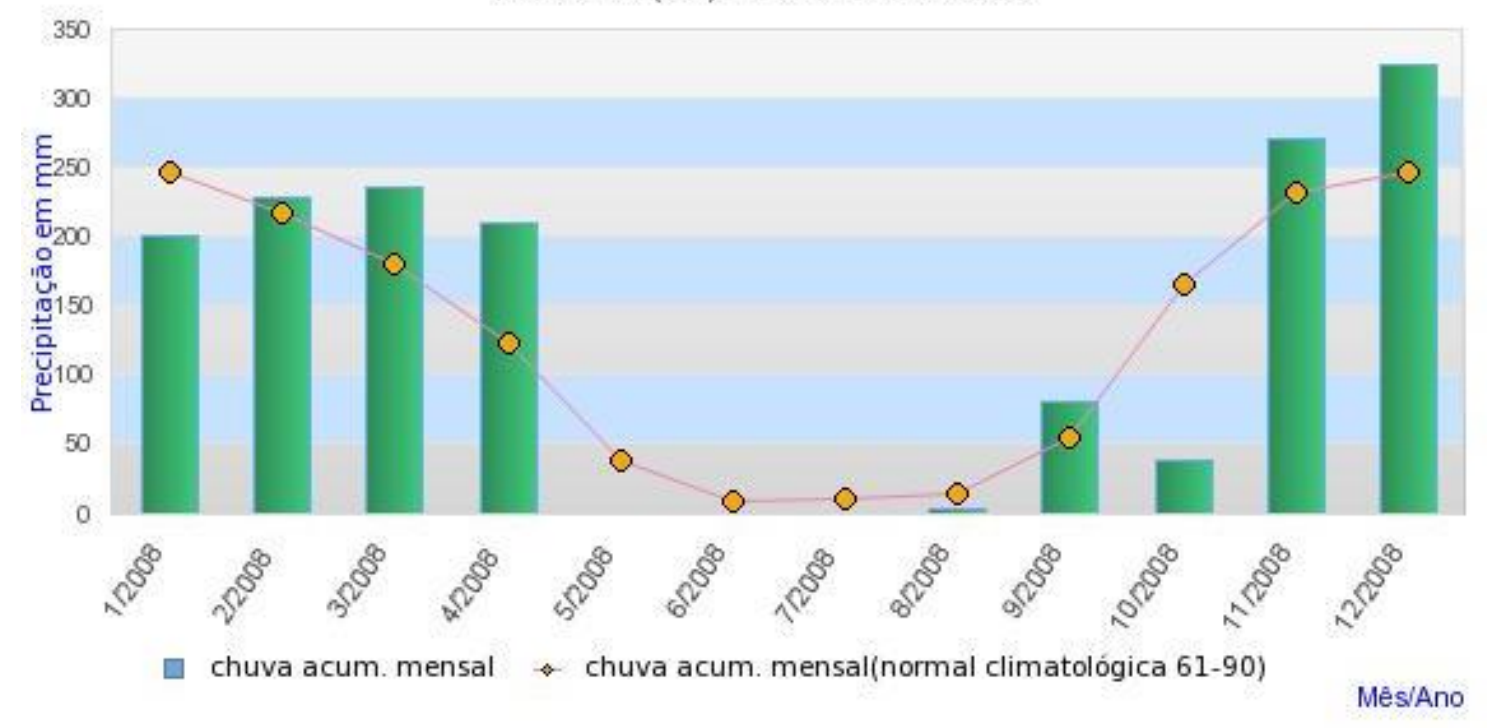

Gráfico 2 - Regime pluviométrico em 2008. Fonte: INMET 
Chuva Acumulada Mensal X Chuva (Normal Climatológica 61-90)

BRASILIA (DF) - Para o Ano: 2009

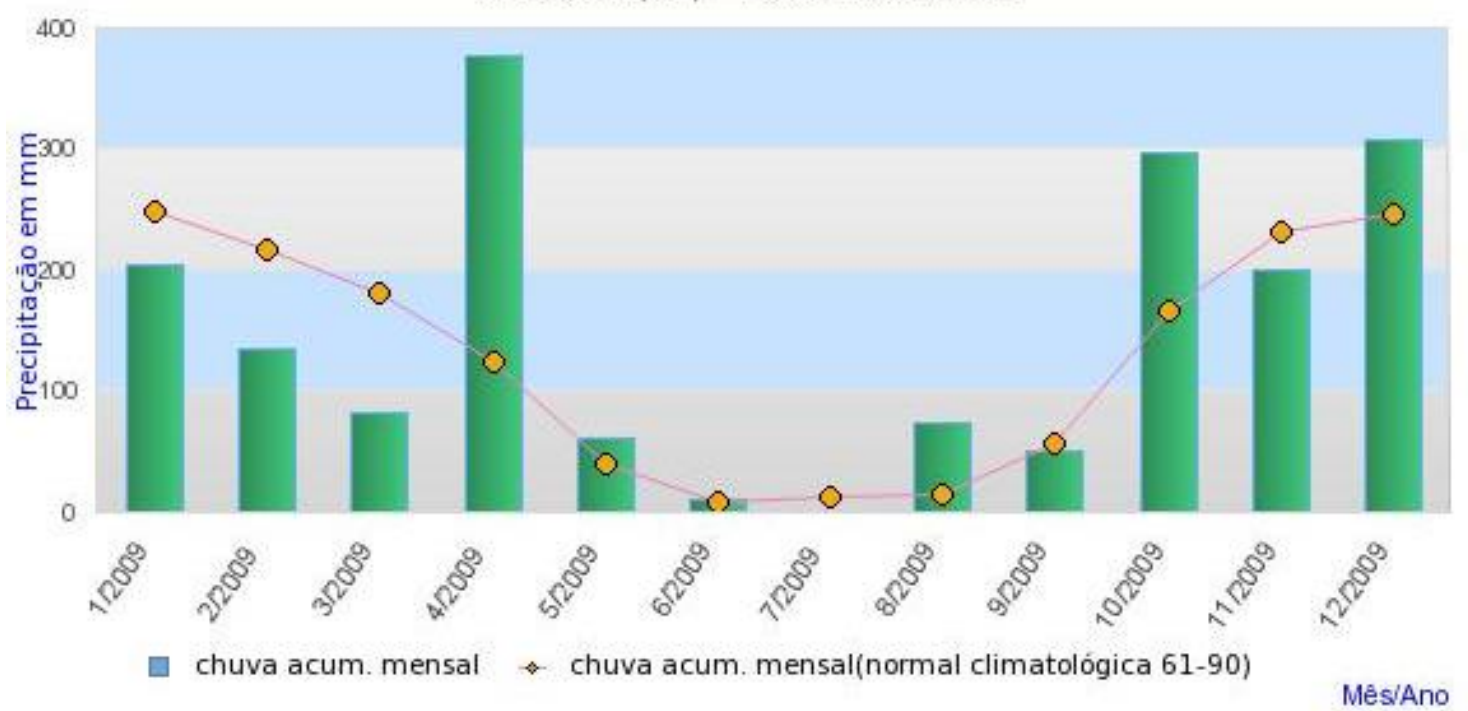

Gráfico 3 - Regime pluviométrico em 2009. Fonte. INMET

Chuva Acumulada Mensal X Chuva (Normal Climatológica 61-90)

BRASILIA (DF) - Para o Ano: 2010

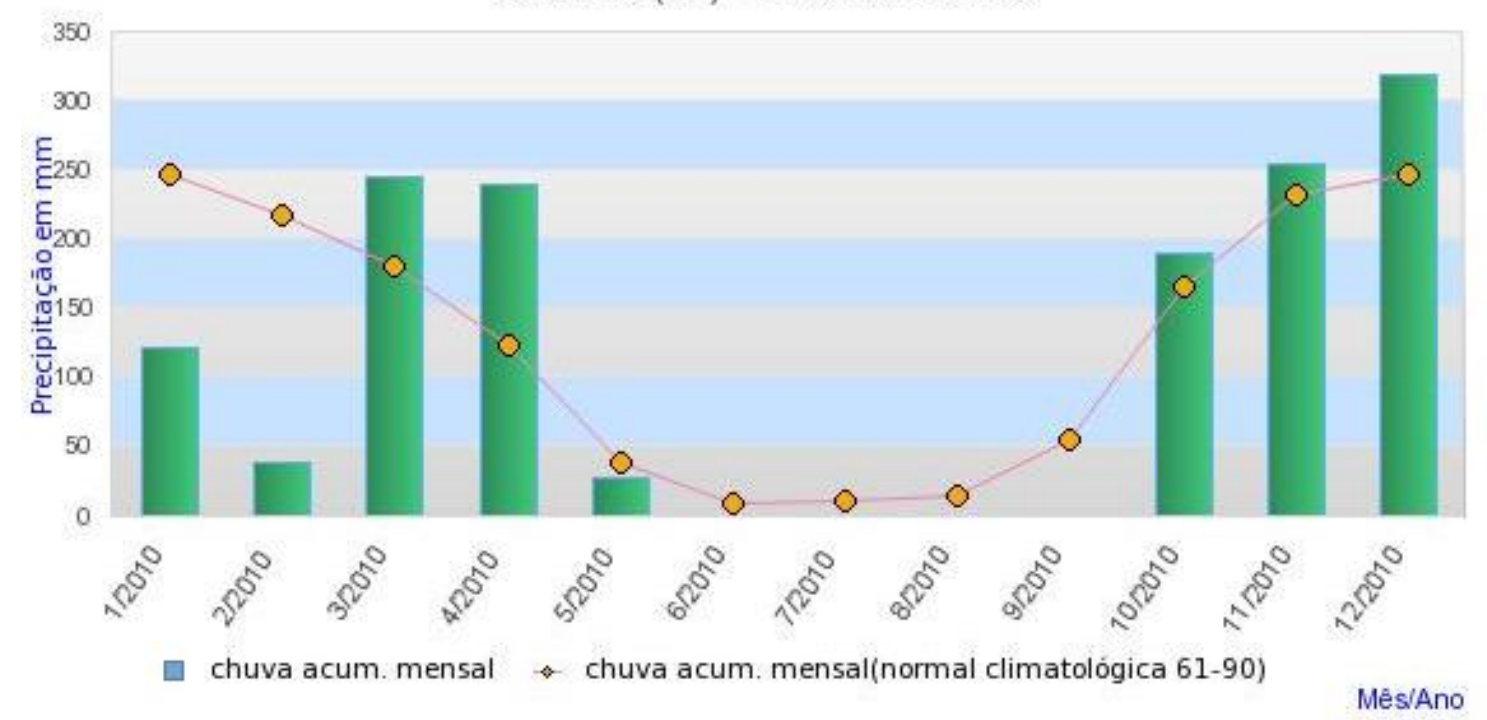

Gráfico 4 - Regime pluviométrico em 2010. Fonte. INMET 
Chuva Acumulada Mensal X Chuva (Normal Climatológica 61-90)

BRASILIA (DF) - Para o Ano: 2011

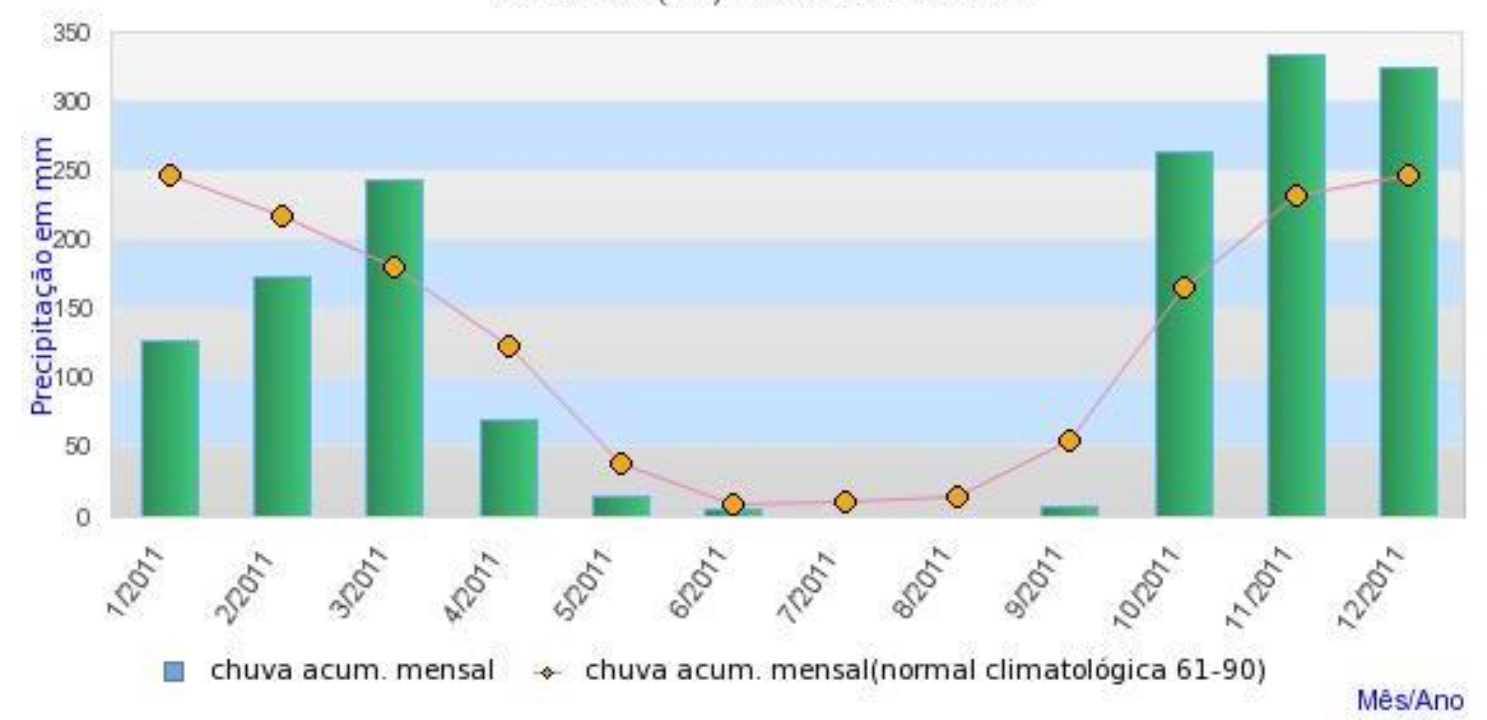

Gráfico 5 - Regime pluviométrico em 2011. Fonte. INMET

Chuva Acumulada Mensal X Chuva (Normal Climatológica 61-90)

BRASILIA (DF) - Para o Ano: 2012

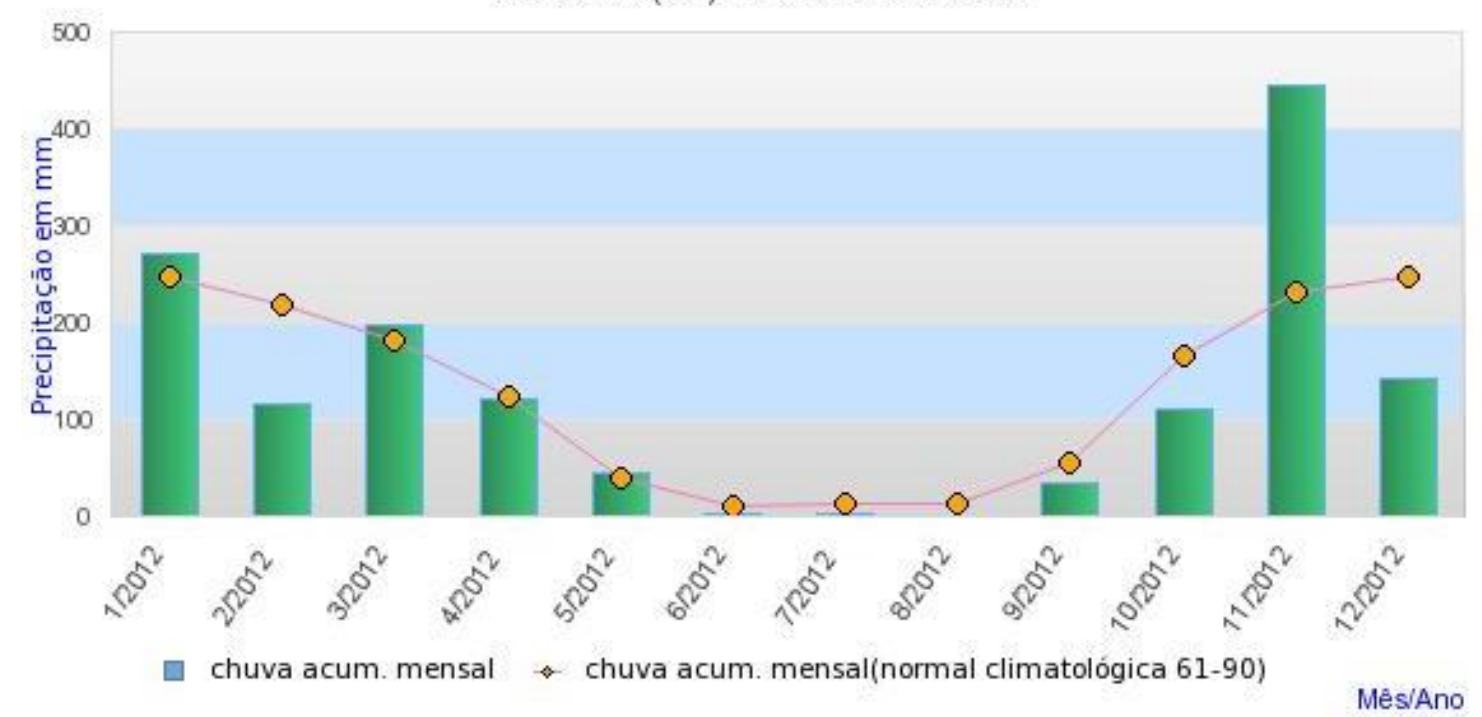

Gráfico 6 - Regime pluviométrico em 2012. Fonte. INMET 
Chuva Acumulada Mensal X Chuva (Normal Climatológica 61-90)

BRASILIA (DF) - Para o Ano: 2013

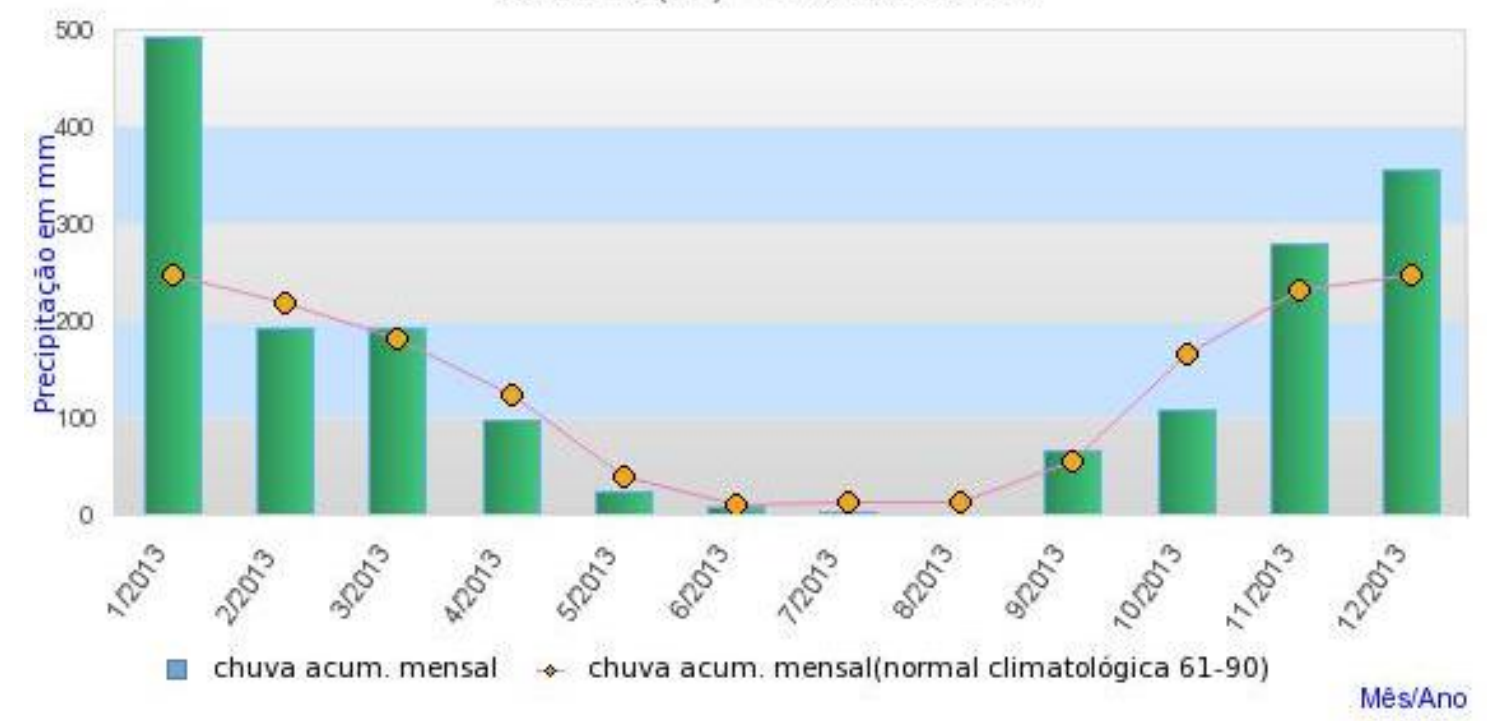

Gráfico 7 - Regime pluviométrico em 2013. Fonte. INMET

Chuva Acumulada Mensal X Chuva (Normal Climatológica 61-90)

BRASILIA (DF) - Para o Ano: 2014

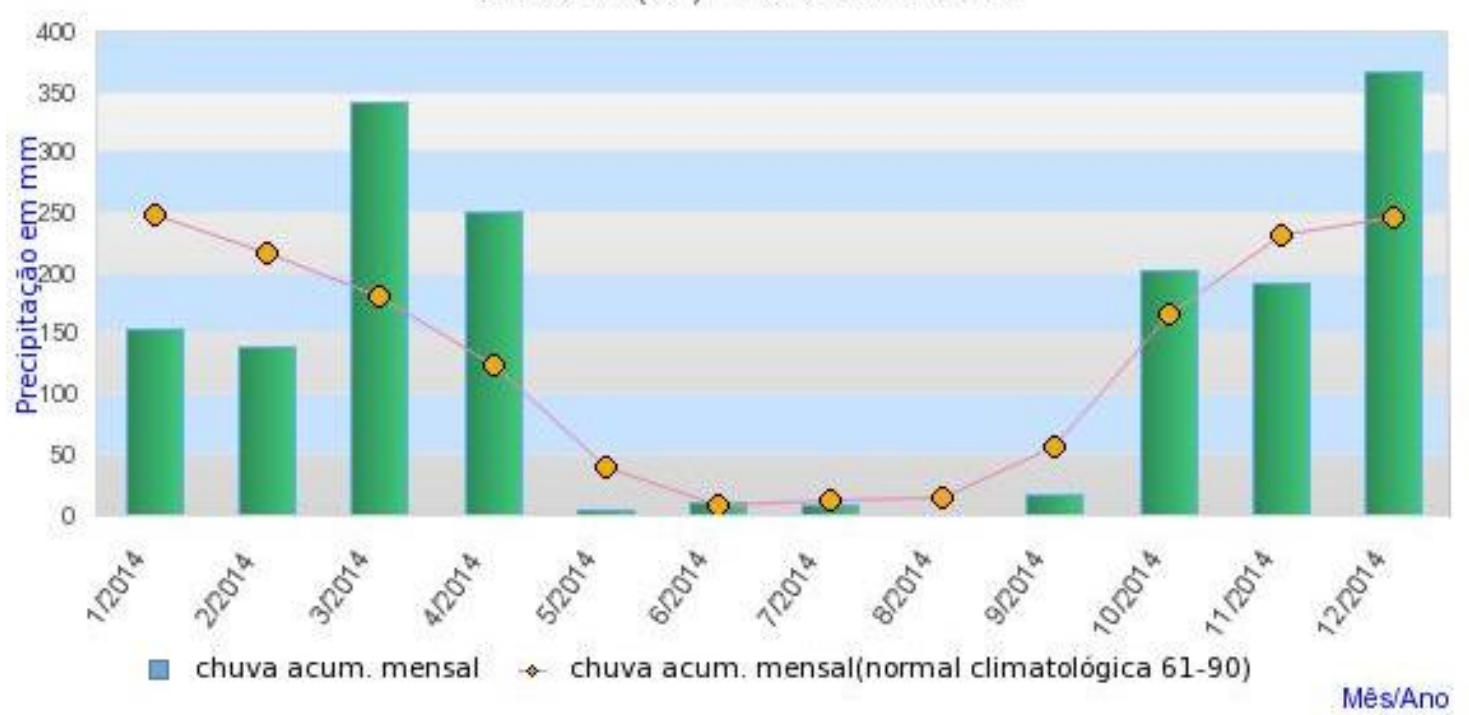

Gráfico 8 - Regime pluviométrico em 2014. Fonte. INMET 
BRASILIA (DF) - Para o Ano: 2015

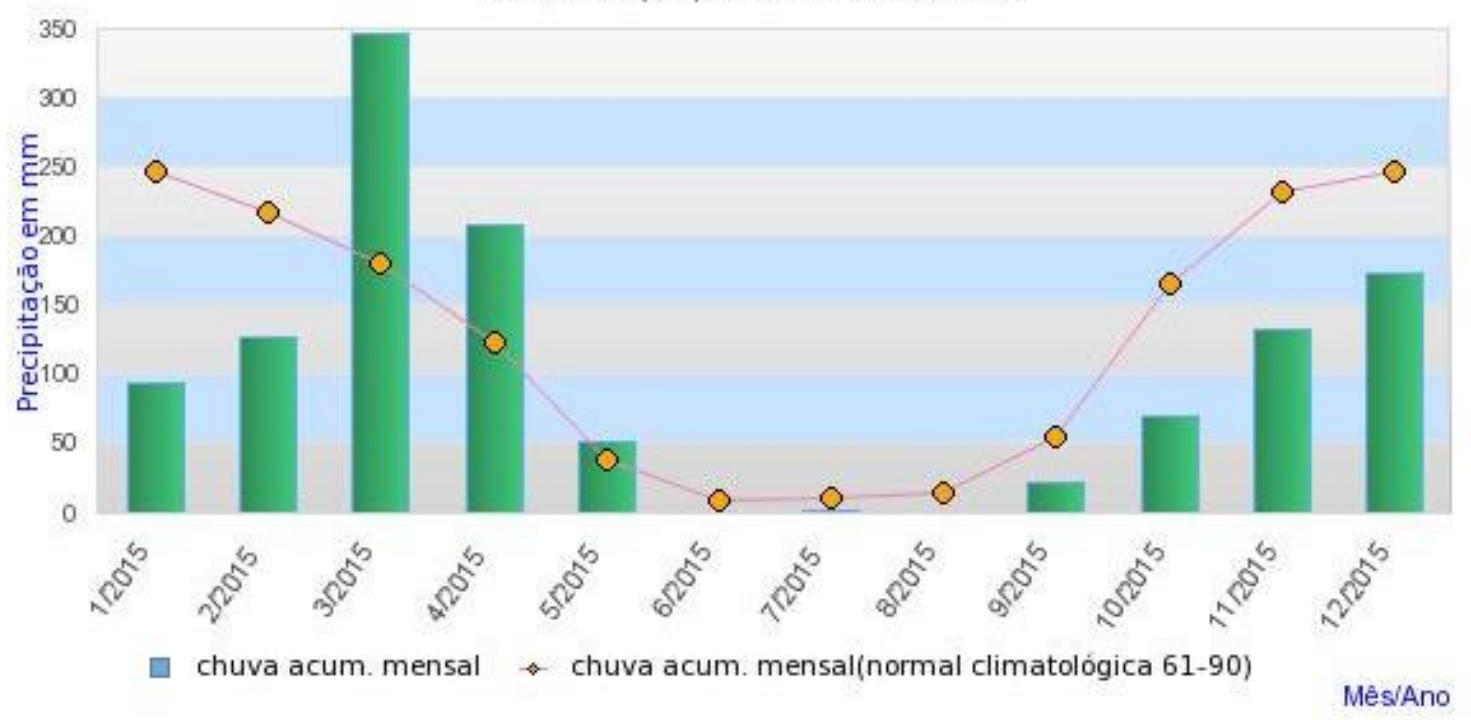

Gráfico 9 - Regime pluviométrico em 2015. Fonte. INMET

Os picos de casos de Hepatite A estão relacionados aos anos de 2008 e 2009. Nesses anos houve casos próximos em localidades caracterizadas por vulnerabilidades ambientais, com o caso da Vila Rabelo em Sobradinho II. Em 2008 os meses de maior notificação foram Junho (6 casos) e Setembro (4 casos). Os índices pluviométricos nesses meses foram, respectivamente de 234,7 mm e 79.8, mm. Esses valores são considerados acima da média de precipitação para os dois meses.

No ano de 2009 a distribuição ocorreu de forma menos concentrada, visto que houve uma diluição do maior número de casos entre os meses do período chuvoso (Fevereiro, Março) e no período seco (Setembro). Os índices mensais alcançados nesses meses foram de $134.8 \mathrm{~mm}$ para fevereiro, $81 \mathrm{~mm}$ em março e $61.2 \mathrm{~mm}$ em maio.

A partir de 2010 as notificações de Hepatite A foram pontuais. Nesse ano (37, $2 \mathrm{~mm}$ no mês notificado) e em 2011 (238,8 mm) os casos ocorreram no período chuvoso, nos meses de fevereiro e abril. Dos 6 casos identificados entre 2012 e 2013, metade ocorreu nos meses de seca e metade no período chuvoso. Todos os 5 casos confirmados em 2014 e 2015 foram no período chuvoso.

A caracterização pluviométrica mostra a ocorrência de casos de Hepatite A não só no período chuvoso, mas também em épocas de seca, conforme consta nos gráficos 10 a 13. Isso corrobora com os fatores causadores da doença, nos quais as questões da higiene e da alimentação se aliam às questões hídricas como fatores causadores do agravo. 
Pluviometria

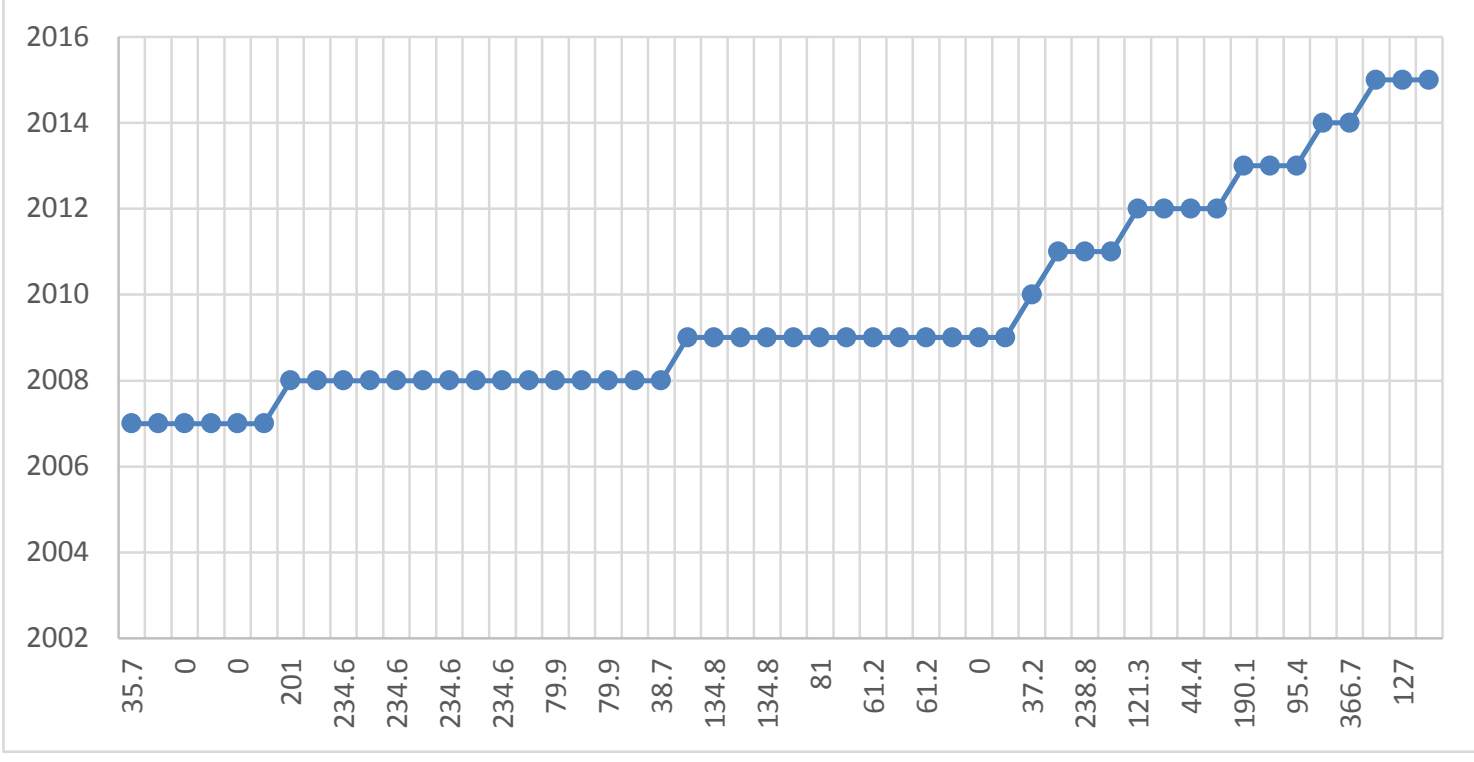

Gráfico 10 - Casos notificados, por ano e a pluviometria mensal. Fonte: SES/DF, INMET.

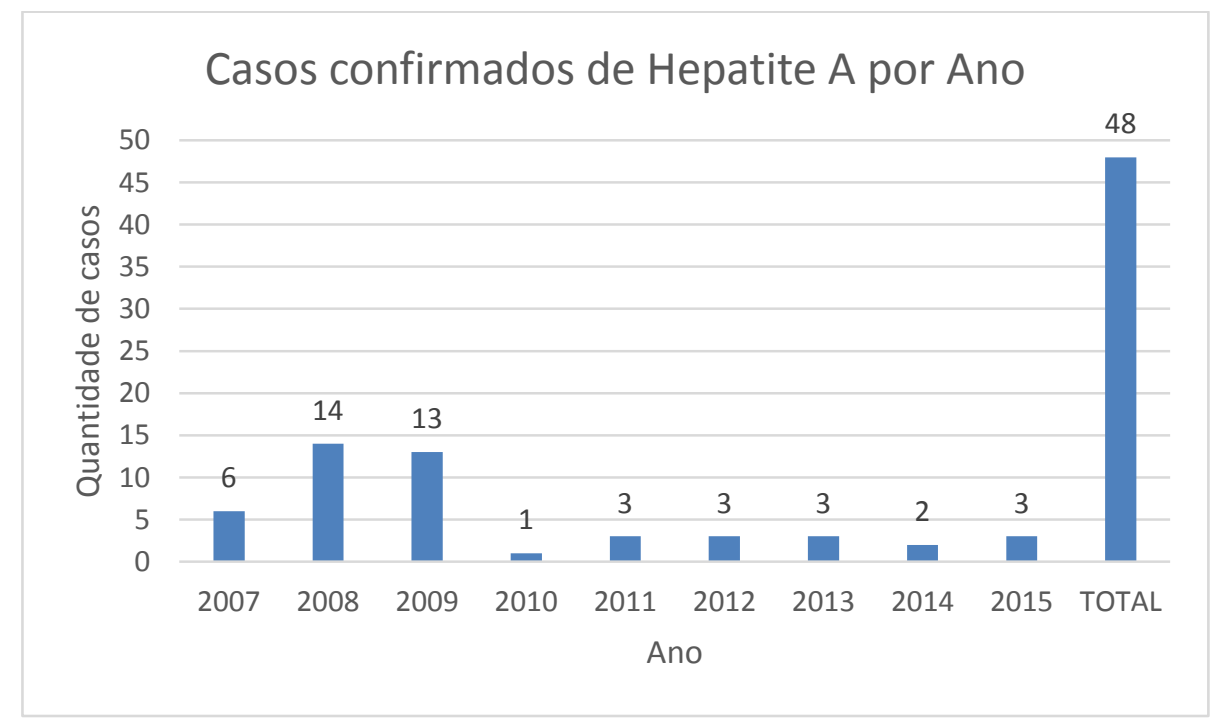

Gráfico 11 - Número de casos notificados por ano. Fonte: SES/DF. 


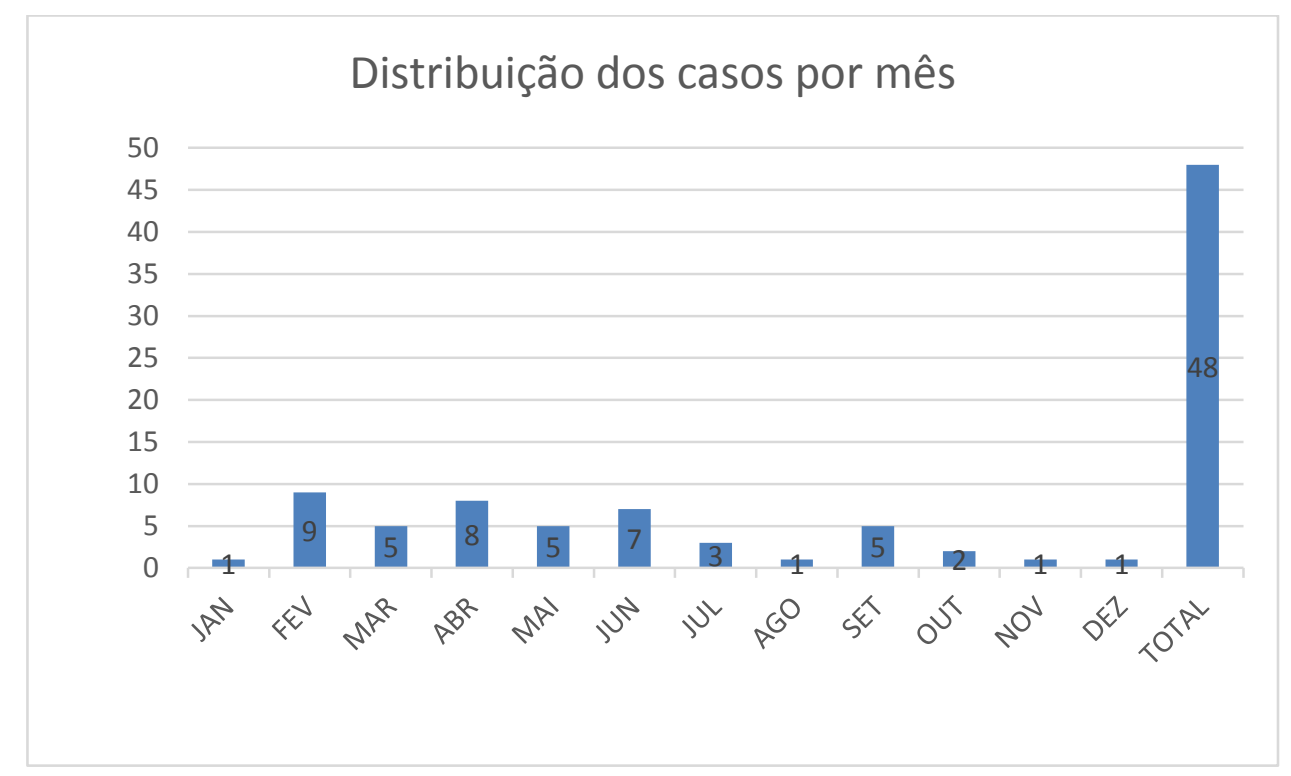

Gráfico 12 - Número de casos notificados por mês. Fonte: SES/DF.

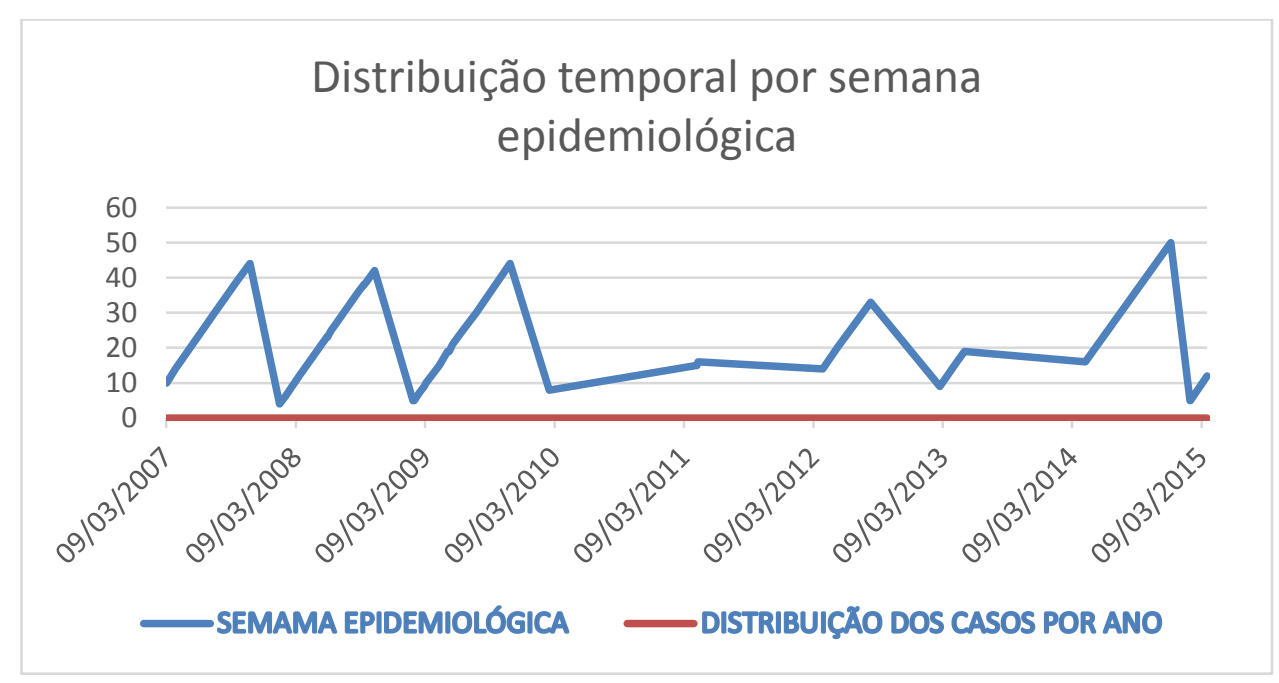

Gráfico 13 - Distribuição dos casos por semana epidemiológica. Fonte: SES/DF. 


\subsection{USO DO SOLO}

O subsídio à análise dos casos de Hepatite A na região de Sobradinho tem como referência o mapeamento da cobertura e uso do solo do Distrito Federal feito por técnicas de classificação supervisionada de produtos de Sensoriamento Remoto realizado pela CODEPLAN (2016). Nesse estudo foram criadas as classes de área construída, correspondente à classe antropizada, formações avânicas, formações florestais, Formações Campestres, Reflorestamento, Agropastoril e outros. Em 2007 a RA de Sobradinho I foi classificada conforme a figura abaixo.

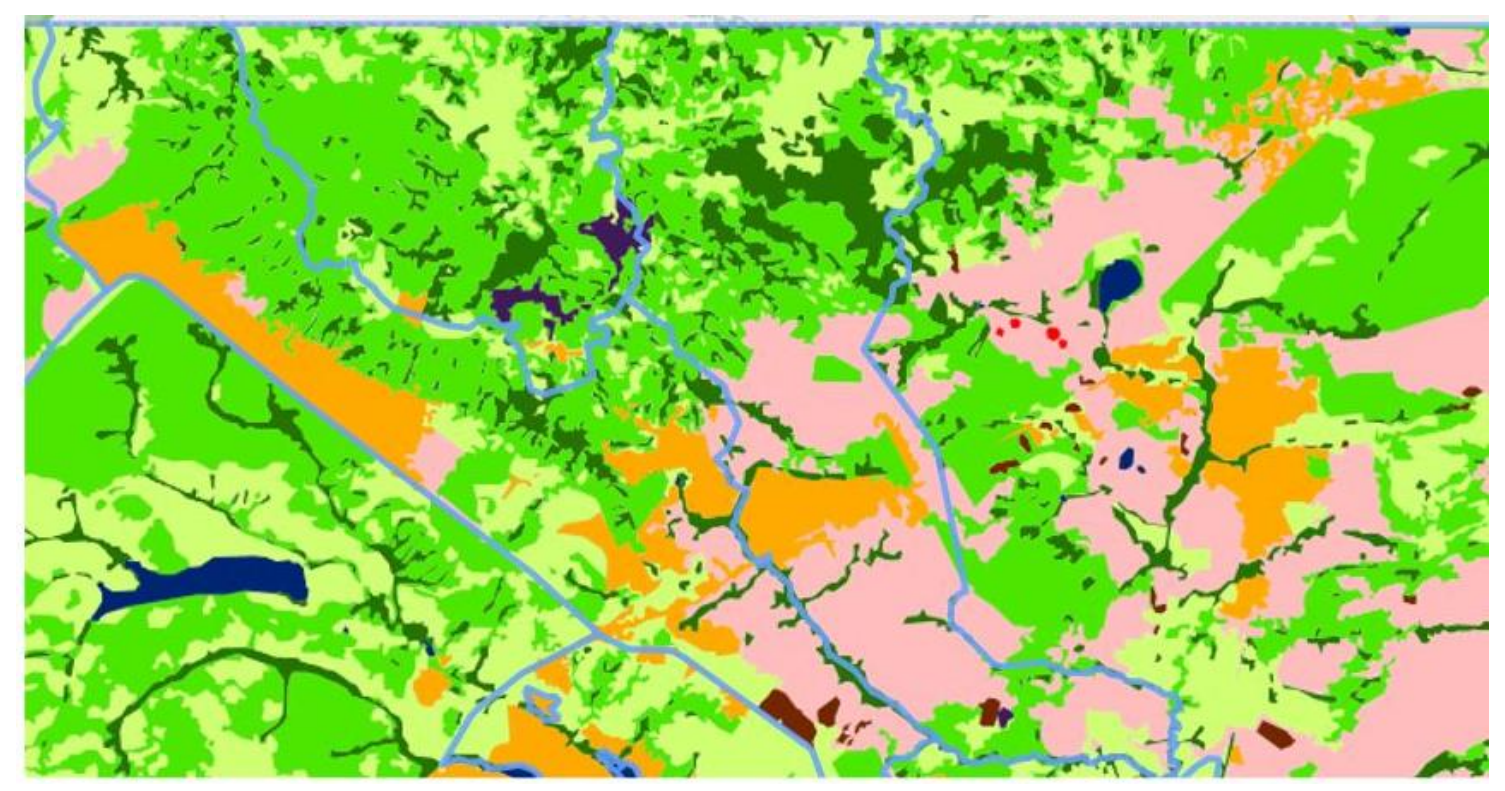

Mapa 18 - Mapa da classificação do uso do solo em 2007. Fonte: CODEPLAN. 
Onde:

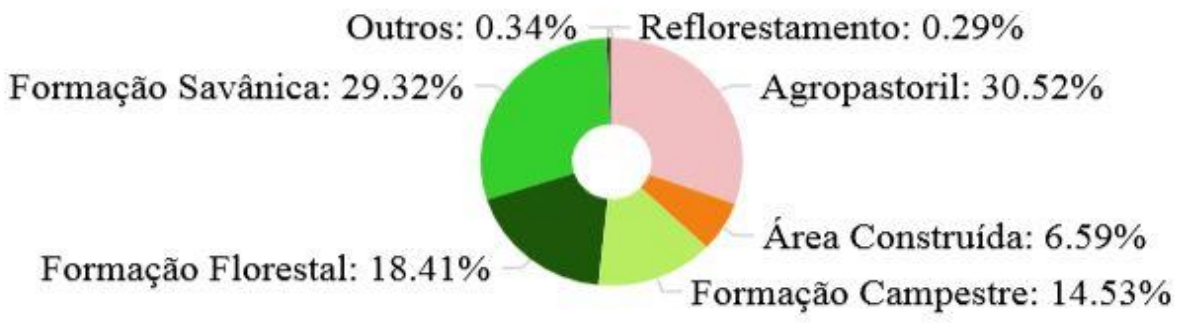

Gráfico 14 - Distribuição da paisagem em Sobradinho. Fonte: CODEPLAN.

O processo de expansão e urbanização mantêm uma relação próxima as áreas de maior probabilidade de ocorrência de Hepatite A devido ao crescimento desordenado acompanhado de más condições de infraestruturas. Conforme mostra o gráfico, Sobradinho tinha em 2007 $6.59 \%$ da sua poligonal constituída por áreas antropizadas. Em Sobradinho II e na Fercal esses índices foram de $20,10 \%$ e $0,92 \%$.

No último ano da análise temporal do agravo Hepatite A (2015) não houve grandes alterações na cobertura do solo quanto às áreas antropizadas. Sobradinho avançou para $6,92 \%$ da sua área total enquanto Sobradinho II obteve 20,34\% de áreas construídas e a Fercal saltou de $0,92 \%$ para $1,54 \%$ do seu território com a intervenção humana.

Diferentemente de décadas passadas, a urbanização na área de estudo ao longo da última década não ocorreu de forma tão acelerada. Isso pode ser um indício do crescimento em uma proporção menor. Sobradinho II ainda é região administrativa de maior representatividade nos casos causados pelo vírus HVA. 


\section{PERFIL SOCIOECONÔMICO}

Para o presente estudo utilizou-se como parâmetro de análise do perfil socioeconômico dos setores censitários do IBGE, com adaptação. De acordo com Ximenes et al. (1999) o uso de setores censitários como unidade espacial de análise para estudos tem como vantagem a representação do nível mais desagregado de dados populacionais e socioeconômicos. Esses dados são coletados sistemática e periodicamente, em nível nacional.

Partindo do pressuposto que o Distrito Federal apresenta características únicas em relação aos demais estados e municípios brasileiros, e a área de estudo abrange regiões administrativas do DF, optou-se pela utilização dos setores censitários como unidade de agregação de dados.

Os casos positivos de notificação de Hepatite A na região de Sobradinho abrange 40 setores censitários (mapa 18). Os maiores setores censitários da área de estudo correspondem às áreas rurais, as quais apresentam baixa densidade populacional.

Nas análises socioeconômicas dos setores censitários (SC), foram considerados dois agrupamentos para o estudo: o primeiro, correspondente aos setores censitários em que houve notificação de casos de Hepatite A e o grupo de setores censitários em que não houve confirmação/ e ou notificação de casos de Hepatite A. Considerou-se, também, o número total de moradores notificados pelo Censo 2010, de acordo com as variáveis expostas para análise. Tais delineamentos foram definidos para melhor identificar a população dos setores censitários com casos confirmados de Hepatite A em relação ao total de setores censitários da área de estudo. O limite delineado foi o da restrição à área da poligonal das três regiões administrativas: Sobradinho, Sobradinho II e Fercal (mapa 19). 


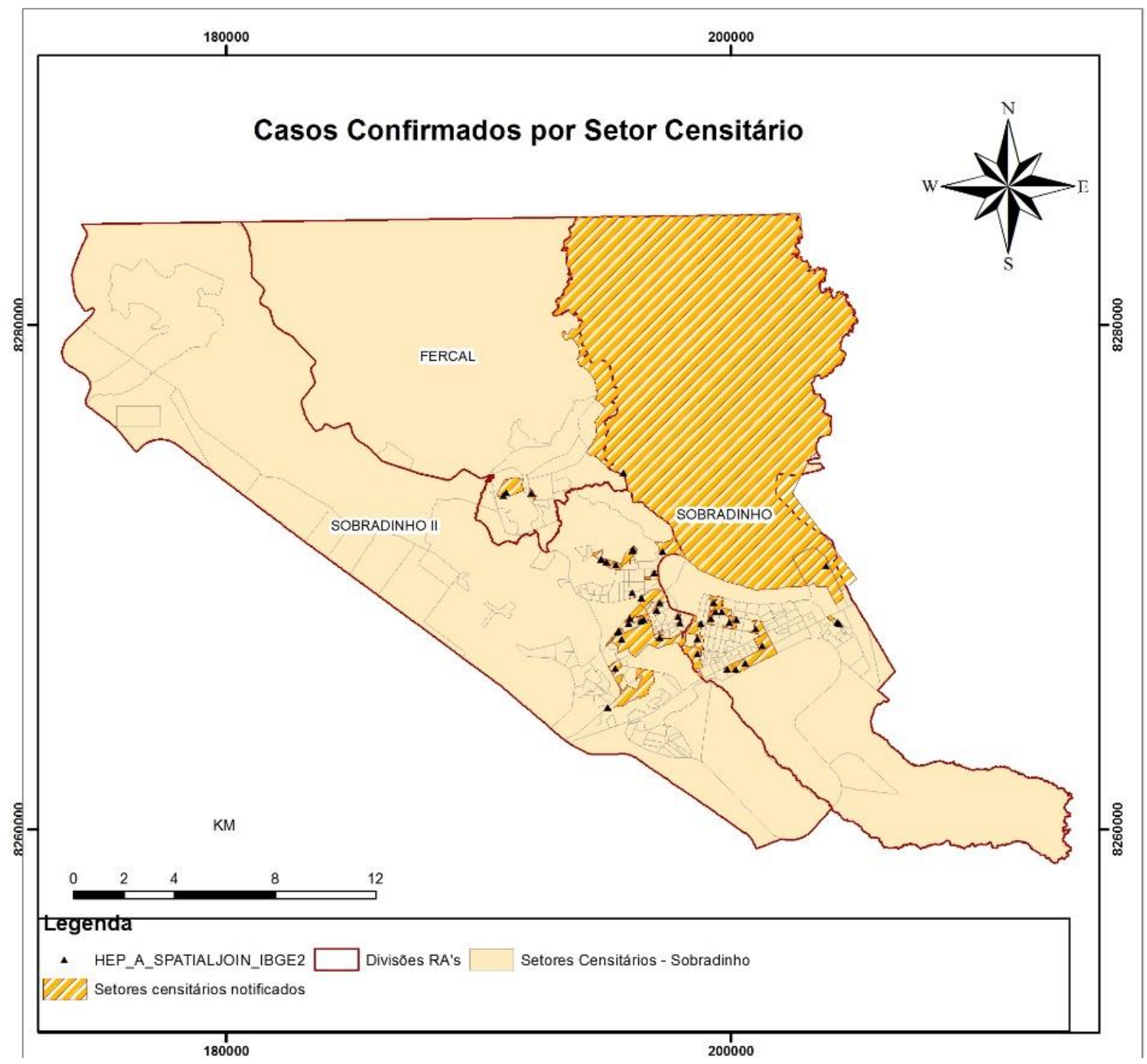

Mapa 19 - Mapa dos Setores Censitários e a confirmação de Hepatite A. Fonte: IBGE; SES/DF.

Quando os setores censitários notificados com Hepatite A são analisados de acordo com a população residente nesse desses locais (mapa 20), pode-se verificar a predominânicia de casos em áreas de maior densidade populacional, com $45,83 \%$ ou 22 casos em setores cuja população se encontra na faixa de moradia entre 818 e 1740 indivíduos. Em 8 casos $(16,66 \%$ do total) estão localizados setores censitários com população entre 626 e 818 pessoas. Cerca de $22,91 \%$ dos setores censitários notificados abrangem áreas com população entre 522 a 626 habitantes. Os setores censitários com as menores taxas de moradores apresentam as menores percentagens de casos confirmados de Hepatite A: 4 casos para os setores censitários cuja 
população se encontra na faixa de 354 a 522 moradores ( 8,33\%) e 3 casos $(6,25 \%)$ para os setores censitários com baixa densidade populacional, entre 0 e 354 moradores.

Portanto, a maior parte dos moradores notificados com Hepatite A residem em setores censitários de maior número de moradores. A maioria desses setores também compreendem áreas menores, normalmente vinculadadas à áreas mais urbanizadas. Numa outra perspectiva, os setores censitários que apresentam um número menor de moradores estão localizados em áreas maiores, com predomínio de zonas rurais. 


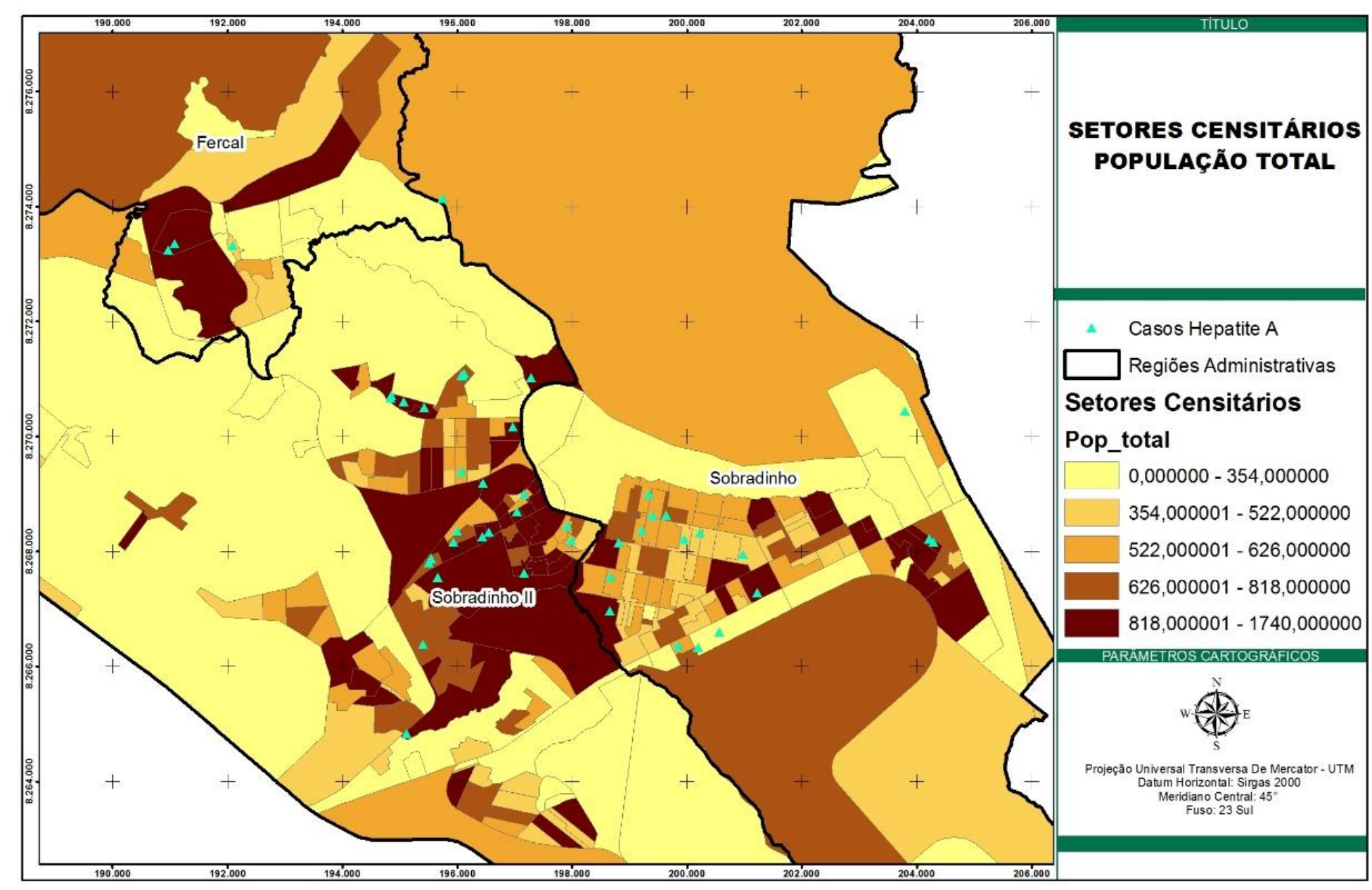

Mapa 20 - Mapa dos setores censitários pela população total. Fonte: IBGE; SES/DF. 


\subsubsection{Sexo}

No período correspondente às notificações confirmadas de casos de hepatite $\mathrm{A}$ na região de Sobradinho, cerca de $17,70 \%$ dos moradores residiam em setores censitários onde houve esses agravos.

Cerca de $52 \%$ dos casos confirmados vinculam-se ao sexo feminino e $47,70 \%$ ao sexo masculino. Essa taxa corrobora para os padrões levantados pelo IBGE no Censo 2010 e nas pesquisas da PDAD da CODEPLAN, na qual há um predomínio de pessoas do sexo feminino habitantes da área de estudo.

Tabela 11 - Número total de habitantes. Fonte: IBGE.

\begin{tabular}{|l|c|c|}
\hline \multicolumn{1}{|c|}{ Sexo } & $\begin{array}{c}\text { Número total de habitantes } \\
\text { na Área de estudo }\end{array}$ & $\begin{array}{c}\text { Número total de habitantes } \\
\text { nos setores censitários } \\
\text { notificados }\end{array}$ \\
\hline Homens & $78.425(47,48 \%)$ & $13.948(47,70 \%)$ \\
\hline Mulheres & $86.748(52,51 \%)$ & $15.290(52,29 \%)$ \\
\hline Total & $165.173(100 \%)$ & $29.238(100 \%)$ \\
\hline
\end{tabular}

\subsubsection{Escolaridade}


O dado do IBGE referentes à escolaridade da população consistiu no ordenamento presente na Lei de Diretrizes e Bases - LDB, na qual a escolaridade é dividida em três classes: Educação Infantil (EI), Ensino Fundamental(EF) e Ensino Médio (EM) com a separação por sexo. Ao se comparar o percentual da população dividida dessas três classes entre os setores censitários notificados com casos de Hepatite A e aqueles setores sem notificação, percebe-se uma equivalência nos números. Essa variável considerou o total de moradores

Na educação infantil, 17,62\% dos moradores do sexo masculino que residem em áreas notificadas encontram-se nessa faixa escolar, enquanto $15,14 \%$ dos residentes nos setores não notificados estão nessa estrutura educacional. Quanto ao sexo feminino, há uma equivalência de proporção de moradores nesse estágio educacional: 17,25\% das moradoras de setores censitários notificados frequentam a escola no ensino infantil, enquanto 17,62\% dizem respeito àquelas estudantes moradoras dos setores não notificados.

Em relação ao ensino fundamental, $24,81 \%$ de pessoas do sexo feminino residentes em setores notificados estão nesse extrato educacional, enquanto $24,72 \%$ das mulheres moradoras de setores não notificados estão no EF. O sexo masculino é representado por 24,72\% para os residentes nos setores notificados por Hepatite e $25,71 \%$ para aqueles vinculados a áreas sem notificação.

No ensino médio o perfil do sexo masculino residente em setores confirmados com Hepatite A corresponde e $8,32 \%$ do total e $8,43 \%$ nos locais sem notificação do agravo. Quanto ao sexo feminino, as taxas são de 8,29\% do sexo feminino cursando o ensino médio e residente em áreas notificadas e 8,38\% nos setores censitários sem confirmação de Hepatite A.

Tabela 12 - Escolaridade por setor censitário notificados e não notificados. Fonte: IBGE.

\begin{tabular}{lrrrrrr} 
Escolaridade & El(MAS) & EF(MAS) & EM(MAS) & El(FEM) & EF(FEM) & EM(FEM) \\
\hline SC sem HVA & $15,14 \%$ & $25,71 \%$ & $8,43 \%$ & $17,62 \%$ & $24,72 \%$ & $8,38 \%$ \\
SC com HVA & $17,62 \%$ & $24,72 \%$ & $8,32 \%$ & $17,25 \%$ & $24,81 \%$ & $8,29 \%$ \\
\hline Total Geral & $\mathbf{7 5 2 4}$ & $\mathbf{1 2 7 1 8}$ & $\mathbf{4 2 1 4}$ & $\mathbf{8 6 9 6}$ & $\mathbf{1 2 2 5 6}$ & $\mathbf{4 1 4 4}$
\end{tabular}




\subsection{3 Água}

Segundo dados do Censo 2010, do total de moradores em setores censitários com casos de Hepatite A, cerca de 97,3\% têm fornecimento de água distribuída para rede oficial, e $2.64 \%$ dos moradores têm acesso à água por meio de poços artesianos. Esses índices diferem em relação aos setores censitários sem notificação de HVA: 89,7\% dos moradores são abastecidos pela rede oficial e cerca de 10,2\% são abastecidos por poços artesianos.

Esses índices são melhores do que aqueles encontrados no Brasil. De acordo com Confalonieri et al (2008), o percentual de abastecimento de água no país nas áreas urbanas subiu 4,5 pontos percentuais entre 1991 e 2003, de 87 para 91,4\%.

Ao se considerar as recentes pesquisas da PDAD da CODEPLAN, cujo foco é a área urbana, os índices são ainda mais elevados: de acordo com a pesquisa, Sobradinho tem 96,46\% das residências em áreas urbanas abastecidas pela rede geral. Sobradinho II apresenta o percentual de $89,48 \%$ de cobertura enquanto a região administrativa da Fercal tem 93,60\% de acesso à rede oficial.

Quando se trata do uso de posso artesiano nas áreas urbanizadas, Sobradinho apresenta $3,57 \%$ dos morados com esse tipo de acesso à água. Sobradinho II mostra um percentual um pouco mais elevado, com 6,01\% enquanto a Fercal é atendida por poços artesianos em 3,80\%.

Esses indicadores permitem avaliar um percentual elevado de assistência à rede oficial de fornecimento de água, ao menos nas áreas urbanas pela pesquisa domiciliar da CODEPLAN. Entretanto, ao se estudar a região por setores censitários, ainda há uma discrepância entre os locais notificados por Hepatite A e aqueles não notificados: nas regiões confirmadas com o agravo apresenta cerca de 7,62\% a menos dos domicílios é coberta pelo abastecimento oficial, enquanto ocorre o inverso no abastecimento por poços.

Tabela 13 - Número de domicílios com acesso a água. Fonte: IBGE.

\begin{tabular}{lcc}
$\begin{array}{c}\text { Abastecimento de } \\
\text { água }\end{array}$ & $\begin{array}{c}\text { No de moradores com água - } \\
\text { RG }\end{array}$ & $\begin{array}{c}\text { No de moradores com água de } \\
\text { Poço }\end{array}$ \\
\hline SC sem notificação & $97,35 \%$ & $89,73 \%$ \\
SC com notificação & $2,64 \%$ & $10,26 \%$ \\
\hline Total Geral & $100 \%$ & $100 \%$
\end{tabular}




\subsubsection{Energia elétrica}

Os dados dos setores censitários referentes ao acesso ao fornecimento de energia elétrica indicam que a região afetada pela notificação de Hepatite A mostra um percentual de $78,9 \%$ do total de domicílios com acesso ao sistema oficial de energia elétrica. Há também o quantitativo de 17,2 \% de residências com medidor comum em suas residências e 2,94\% não têm medidor comum. Apenas $0,18 \%$ dos habitantes não possuem acesso à energia elétrica.

Quando comparados aos outros setores censitários da área de estudos os percentuais diferem: 82,21\% dos moradores de domicílios têm energia elétrica, sendo 15,08\% com medidores comuns nas residências e 2,45\% sem medidores comuns e 0,25\% não têm abastecimento de energia elétrica em suas residências.

Nota-se, portanto, uma pequena diferença nas taxas de fornecimento de energia elétrica. Os setores censitários com casos de Hepatite A apresentaram um valor inferior na taxa de acesso à energia elétrica comparada aos setores não notificados. Esse diagnóstico confirma estudos anteriores de literatura nos quais a infraestrutura é um fator importante para a análise de regiões mais propensas à ocorrência de casos de Hepatite A.

Tabela 14 - Número de domicílios com acesso a energia elétrica. Fonte: IBGE.

\begin{tabular}{lrrrc} 
Acesso EE & \multicolumn{1}{c}{$\begin{array}{l}\text { Moradores } \\
\text { com EE }\end{array}$} & $\begin{array}{c}\text { Moradores } \\
\text { sem EE }\end{array}$ & $\begin{array}{l}\text { Moradores com } \\
\text { medidor comum }\end{array}$ & $\begin{array}{c}\text { Moradores sem } \\
\text { medidor comum }\end{array}$ \\
\hline SC sem & $82,21 \%$ & $0,25 \%$ & $15,08 \%$ & $2,45 \%$ \\
\hline $\begin{array}{l}\text { notificação } \\
\text { SC com }\end{array}$ & $78,91 \%$ & $0,18 \%$ & $17,95 \%$ & $2,94 \%$ \\
notificação & & & &
\end{tabular}




\subsubsection{Lixo}

A população total, no quesito, no coletado na área de estudo corresponde à 158633 habitantes. As áreas atingidas pela confirmação de notificados com HVA possuem um total de 27709 moradores com sistema de coleta de lixo, correspondente à $17,42 \%$ do total da população da área de estudo. A taxa de $82,53 \%$ de moradores com acesso à coleta de lixo abarca os setores censitários sem notificação de casos de Hepatite A durante o período do estudo.

De acordo com dados do SLU (2016) a região de Sobradinho é contemplada pela coleta convencional. A coleta seletiva é contemplada nas áreas urbanas de Sobradinho e Sobradinho II, porém as áreas rurais e a região administrativa da Fercal não são atendidas para esse serviço.

Apesar da existência de serviços regulares de coleta e gestão de resíduos sólidos, o mapeamento dos focos de lixo identificou a deposição de resíduos principalmente nas áreas periféricas da área de estudo, próximo à área urbanizada.

Tabela 15 - Número de domicílios com acesso a coleta de lixo. Fonte: IBGE.

\begin{tabular}{lcr} 
Acesso coleta de lixo & Domicílios com acesso à coleta de lixo & $\%$ \\
\hline SC não notificados & 130924 & 82,53 \\
SC notificados & 27709 & 17,46
\end{tabular}




\subsubsection{Esgoto}

O estudo do Censo 2010 apresentou duas variáveis quanto ao esgotamento sanitário vinculados às residências: Rede Geral e Fossa Séptica. Do total de moradores em áreas notificadas, $62,58 \%$ são atendidos pela rede oficial de esgotamento sanitário e 37,41\% pessoas residem em moradias com esgoto por fossa. Os índices de acesso à Rede Geral diminuem quando comparados aos setores censitários sem notificação, pois atinge um total de $57,41 \%$ dos moradores. O acesso à fossa séptica, ao contrário, tem um aumento percentual, com 42,64\% dos residentes com esse tipo de esgotamento em suas residências. Quase todos os setores censitários pertencem a zonas urbanas, fato que pode ser um indício para explicar porque os locais com notificações de Hepatite A apresentaram taxas proporcionais melhores de acesso à rede oficial de esgoto. Essa situação pode ser confirmada pelos trabalhos da Pesquisa Domiciliar de Amostra de Domicílios - PDAD da CODEPLAN (2011;2013;2015) o qual confirma as melhores taxas em ambientes urbanos em relação aos rurais. $\mathrm{O}$ estudo também confirma a alta porcentagem de acesso aos serviços públicos de água e esgoto no Distrito Federal.

Tabela 16 - Número de domicílios com acesso ao esgoto. Fonte: IBGE.

\begin{tabular}{|c|c|c|c|}
\hline $\begin{array}{l}\text { Rede } \\
\text { de esgoto }\end{array}$ & $\begin{array}{l}\text { Moradores domicílios } \\
\text { com esgoto }\end{array}$ & $\begin{array}{l}\text { Moradores domicílios } \\
\text { com fossa séptica }\end{array}$ & Total \\
\hline SC com notificação & $62,58 \%$ & $37,41 \%$ & $100 \%$ \\
\hline SC sem notificação & $57,35 \%$ & $42,64 \%$ & $100 \%$ \\
\hline
\end{tabular}

\subsubsection{Renda}


A distribuição de renda por setor censitário no CENSO 2010 estabeleceu 7 níveis de rendimento para a população. Verificou-se a predominância de uma distribuição de renda com melhores rendimentos nos setores censitários onde não houve confirmação de casos de Hepatite A. Os setores censitários com casos de HVA apresentam índices inferiores de renda.

A maior parte da população dos setores censitários com casos notificados apresentou uma renda de até 3 salários mínimos como rendimento mensal, correspondente à 71,66\% do total dos setores selecionados. Essa proporção representa 59,89\% nos demais setores censitários da área de estudo. Cerca de $10,27 \%$ da população têm rendimentos de até 5 salários mínimos, contra $12,28 \%$ nas outras áreas.

Quando a renda é de até 10 salários mínimos, 12, 35\% da população com setores notificados com o agravo são remuneradas nessa faixa de remuneração, contra 17,18\% nas demais regiões estudadas. Na faixa de remuneração de até 15 salários mínimos, 2,93\% dos moradores da região notificada apresentam essa renda e 4,45\% nos outros setores.

Um percentual de 1,61\% dos moradores de áreas notificadas recebe até 20 salários mínimos, diferente das áreas não notificadas, onde 3,40\% da população têm rendimentos com o mesmo nível salarial. Para aqueles que recebem acima de 20 salários mínimos e pertencem aos setores censitários com casos de Hepatite A o percentual foi de $0,89 \%$, abaixo dos 2,40\% relacionados à população dos outros setores censitários. A notificação de moradores sem rendimentos representou $0,26 \%$ nos setores notificados e $0,33 \%$ nos setores não notificados.

A distribuição percentual de renda dos moradores de Sobradinho indica rendimentos maiores para aqueles residentes em setores censitários sem notificação por Hepatite A quando comparados aos locais notificados.

Tabela 17 - Número de domicílios por rendimento mensal. Fonte: IBGE.

\begin{tabular}{lccccccc} 
& Até & Até & Até & Até & Até & Acima de & Sem \\
Renda & $\mathbf{3} \mathbf{S M}$ & $\mathbf{5 ~ S M}$ & $\mathbf{1 0} \mathbf{S M}$ & $\mathbf{1 5} \mathbf{S M}$ & $\mathbf{2 0} \mathbf{S M}$ & $\mathbf{2 0} \mathbf{S M}$ & Renda \\
\hline $\begin{array}{l}\text { SC sem } \\
\text { notificação }\end{array}$ & $59,89 \%$ & $12,28 \%$ & $17,18 \%$ & $4,49 \%$ & $3,40 \%$ & $2,40 \%$ & $0,33 \%$ \\
$\begin{array}{l}\text { SC com } \\
\text { notificação }\end{array}$ & $\mathbf{7 1 , 6 6 \%}$ & $10,27 \%$ & $12,35 \%$ & $2,93 \%$ & $1,61 \%$ & $0,89 \%$ & $0,26 \%$ \\
\hline Domicílios & $\mathbf{5 5 5 2 8}$ & $\mathbf{1 0 7 3 0}$ & $\mathbf{1 4 7 1 1}$ & $\mathbf{3 8 0 1}$ & $\mathbf{2 7 9 2}$ & $\mathbf{1 9 3 2}$ & $\mathbf{2 8 9}$ \\
\hline
\end{tabular}




\section{CONDIDERAÇÕES FINAIS}

Os resultados da pesquisa de dissertação permitiram analisar a contextualização das áreas onde houve casos confirmados de Hepatite A na região de Sobradinho. Os fatores ambientais, sociais e econômicos formaram importantes bases para essas análises dentro da área de estudo.

Sob o viés dessas categorias de análises pode-se inferir que os fatores citados são importantes para a caracterização e contextualização local ou do endereço dos notificados por Hepatite A. Os dados ambientais relativos ao MDT e à Declividade nas zonas urbanas mostraram-se relevantes para a compreensão do padrão de ocupação do território.

Entretanto, os fatores relacionados à infraestrutura do local de habitação do notificado e principalmente a renda dos moradores se destacaram na comparação entre os setores censitários notificados com casos de Hepatite A e os setores sem notificação, com a confirmação de menor renda nos locais confirmados com o HVA, o que corrobora com a literatura.

A utilização dos setores censitários como unidade de análise possibilitou uma análise local da área de estudo, pois o foco apenas na divisão das regiões administrativas não permitiria identificar as diferenças sociais, ambientais e econômicas dentro do local objeto de estudo. Um exemplo dessa diferença está em Sobradinho II, região ocupada tanto por condomínios de renda elevada como condomínios de renda mais baixa.

A predominância de casos de Hepatite A em áreas urbanas ou periurbanas confirmou a característica do agravo em locais urbanizados e de maior concentração populacional e de piores condições socioeconômicas. Em regiões mais pobres localizadas próximas ou dentro de zonas rurais o número de notificações foi pequeno. Exemplo disso está na Fercal, onde as 3 notificações registradas foram relacionadas a áreas urbanas. A região contemplou apenas $6.25 \%$ do total de casos, apesar de apresentar níveis de renda e de infraestrutura inferiores às das regiões administrativas de Sobradinho e Sobradinho II. Como comparação, as duas localidades citadas tiveram 19 e 26 notificações, respectivamente, entre 2007 e 2015 . Os atuais indicadores não refletem necessariamente em nível local aquilo de que se espera para uma determinada localidade.

A análise da proximidade de corpos hídricos e dos focos de lixos foi importante para caracterização ambiental da área de estudo. Porém não foi notada uma relação direta entre as 
notificações de Hepatite A e esses dois parâmetros. Uma possibilidade para tratar melhor dessa questão seria verificar, em trabalhos futuros, a influência da institucionalização da Hepatite nas escolas, pois $25 \%$ dos casos foram relacionados a esses ambientes.

Os dados dos setores censitários permitiram verificar uma maior aproximação dos reais fatores causadores de Hepatite A, principalmente àqueles vinculados ao saneamento e ao acesso aos serviços de necessidade básica como água, energia elétrica e esgotamento.

As informações contidas nas fichas de notificação foram subsídios importantes para entender o padrão de distribuição espacial dos casos de Hepatite A por meio da metodologia adotada na área de estudo. O Distrito Federal ainda é uma unidade da federação pouco estudada em relação às pesquisas epidemiológicas em Hepatite A e este ainda é um desafio a ser enfrentado no campo da epidemiologia. Para perspectivas futuras sugere-se um aprofundamento da relação entre a epidemiologia e a Hepatite A em outras áreas ou regiões administrativas do DF, a fim de se verificar e comparar o padrão de distribuição da doença em outros locais na unidade federativa. 


\section{REFERÊNCIAS}

ANDERSEN, R. M. Revisiting the behavioral model and access to medical care: does it matter? J Health Soc Behav, 36 :1-10, 1995.

ANDREAZZI, Marco Antonio Ratzsch; BARCELLOS, Christovam; HACON, Sandra. Velhos indicadores para novos problemas: a relação entre saneamento e saúde. Revista Panamericana de Salud Publica, v. 22, n. 3, p. 211-217, 2007.

Organização espacial, saúde e qualidade de vida: análise espacial e uso de indicadores na avaliação de situações de saúde. Informe epidemiológico do SUS, v. 11, n. 3, p. 129-138, 2002.

BARCELLOS, Christovam; RAMALHO, W. Situação atual do geoprocessamento e da análise de dados espaciais em saúde no Brasil. Revista IP Informática Pública, 4 : 221-30, 2002.

BASSO, Luís Alberto; RIGHI, Eleia. Casos de hepatite e leptospirose no Município de Porto Alegre-RS entre os anos de 2007 a 2011. Hygeia: Revista Brasileira de Geografia Médica e da Saúde, v. 11, n. 20, p. 66, 2015.

BRAGA, José Olavo Nogueira et al. O uso do geoprocessamento no diagnóstico dos roteiros de coleta de lixo da cidade de Manaus. Engenharia Sanitária e Ambiental, v. 13, n. 4, p. 387-394, 2008.

BRASIL. Ministério da Saúde. Guia de Vigilância Epidemiológica. 7. ed. Brasília: Ministério da Saúde, 2009. Disponível em: <http://portal.saude.gov.br/portal/arquivos/pdf /gve_7ed_web_atual.pdf>. Acesso em: 3 abr. 2016.

BRASIL. Ministério da Saúde. Secretaria de Vigilância em Saúde. Departamento de Vigilância Epidemiológica. Doenças infecciosas e parasitárias: guia de bolso. 7. ed rev. Brasília: Ministério da Saúde, 2010.

BOSCH, A. et al. Warerborne Viruses Associated With Hepalitis Outbreak. Joumal American Work Water Association, 83:3, p. 80-83, 1991.

BRITTO, L. S. F. Sistema de Informações e Agravos de Notificação-SINAN. In.: FUNDAÇÃO NACIONAL DE SAÚDE. ANAIS DO SEMINÁRIO DE VIGILÂNCIA EPIDEMIOLÓGICA. Brasília: Ministério da Saúde, p. 145-146, 1993.

CAIRNCROSS, S.; FEACHEM, R. G. Environmental health engineering in the tropics: an introductory text. Chichester: John Wiley \& Sons, 1990.

CÂMARA, Gilberto; DAVIS, Clodoveu. Introdução. In: CÂMARA, G; DAVIS, C.; MONTEIRO, A. M. V. Introdução à ciência da geoinformação. São José dos Campos: INPE, 2001. Disponível em:<http://www.dpi.inpe.br/gilberto/livro/introd/>. Acesso em: 8 jun. 2016. 
CÂMARA, Gilberto et al. Análise espacial e geoprocessamento. In: Análise espacial de dados geográficos. São Paulo: INPE, 2002. v.2

CARVALHO, Marília Sá; PINA, Maria de Fátima Sá; SANTOS, Simone Maria dos. Conceitos básicos de sistemas de informação geográfica e cartografia aplicadas a saúde. Brasília: Organização Pan-Americana da Saúde, 2000. Disponível em: < http://www.bvsde.paho.org/cursode/fulltext/Livro_cartog_SIG_saude.pdf>. Acesso em: 8 jun. 2016.

CASTELLANOS, P. L. O ecológico na epidemiologia. In: ALMEIDA-FILHO, N. et al. Teoria epidemiológica hoje: fundamento, interfaces e tendências. Rio de Janeiro: Abrasco, 1998. p. 129-147. (Série Epidemiológica 2).

CLEMENS, Sue Ann Costa et al. Soroprevalência para Hepatite A e Hepatite B em quatro centros no Brasil. Rev. Soc. Bras. Med. Trop., v. 33, n. 1, p. 1-10, 2000.

COMPANHIA DE DESENVOLVIMENTO DO PLANALTO CENTRAL - CODEPLAN. Pesquisa Distrital por Amostra de Domicílios: Fercal: PDAD 2015. Disponível em:< http://www.codeplan.df.gov.br/images/CODEPLAN/PDF/pesquisa_socioeconomica/pdad/20 16/PDAD_Fercal_2015.pdf>. Acesso em: 12 fev. 2016.

Pesquisa Distrital por Amostra de Domicílios: Sobradinho: PDAD 2015. Disponível em: <http://www.codeplan.df.gov.br/images/CODEPLAN/PDF/pesquisa_ socioeconomica/pdad/2015/PDAD_Sobradinho_2015.pdf>. Acesso em: 9 abril 2016.

Pesquisa Distrital por Amostra de Domicílios: Sobradinho II : PDAD 2015. 2015. Disponível em: <http://www.codeplan.df.gov.br/images/CODEPLAN/PDF/pesquisa_ socioeconomica/pdad/2015/PDAD_Sobradinho_II.pdf >. Acesso em: 18 fev. 2016.

Síntese de informações socioeconômicas. Brasília: Codeplan, 2014.

CONFALONIERI, Ulisses; HELLER, Léo; AZEVEDO, Sandra. Água e Saúde: aspectos globais e nacionais. In: BICUDO, C. E. M.; TUNDISI, J. G.; SCHEUENSTHUL, M. C. B. Águas do Brasil: análises estratégicas. São Paulo: Instituto de Botânica, 2010. p. 27-42.

CZERESNIA, Dina; RIBEIRO, Adriana Maria. O conceito de espaço em epidemiologia: uma interpretação histórica e epistemológica. Cadernos de Saúde Pública, Rio de Janeiro, v. 16, n. 3, p. 595-605, 2000.

DANIEL, L.A. Processos de desinfecção e desinfetantes alternativos na produção de água potável. Rio de Janeiro: ABES, 2001. p.1-23.

DISTRITO FEDERAL (Estado). Governo do Distrito Federal. Secretaria de Obras. Plano Diretor Local. Brasília, 1997.

DISTRITO FEDERAL (Estado). Governo do Distrito Federal. Secretaria de Estado de Defesa Civil. Levantamento das Áreas de risco do Distrito Federal: Área I (Vila Rabelo I e II) e Área II (Fercal). 2012. 
DONABEDIAN, A. The assessment of need. In: DONABEDIAN, A (Ed.). Aspects of medical care administration. Cambridge: Harvard University Press, 1973. p. 58-77.

DOWBOR L, TAGNIN, A. (Org.). Administrando a água como se fosse importante: gestão ambiental e sustentabilidade. São Paulo: Senac, 2005.

Empresa Brasileira de Pesquisa Agropecuária - EMBRAPA. Serviço Nacional de Levantamento e Conservação de Solos Rio de Janeiro, RJ. Súmula da $\mathbf{1 0}^{\circ}$ Reunião Técnica de Levantamento de Solos. Rio de Janeiro, 1979. 83p. (EMBRAPA-SNLCS. Micelânea, 1).

FERRAZ ST. Cidades saudáveis: uma urbanidade para 2000. Brasília: Paralelo 15, 1999.

FERREIRA, Marcelo Urbano. Epidemiologia e Geografia: o complexo patogênico de Max. Sorre. Cadernos de Saúde Pública, Rio de Janeiro, v. 7, n. 3, p. 301-309, 1991.

FERREIRA, Cristina Targa; SILVEIRA, TR da. Hepatites virais: aspectos da epidemiologia e da prevenção. Rev. Bras. Epidemiol., v. 7, n. 4, p. 473-87, 2004.

FRANCO, Regina Maura Bueno. Protozoários de veiculação hídrica: relevância em saúde pública. Rev. Panam. Infectol., v. 9, n. 4, p. 36-43, 2007.

FUNASA FUNDAÇÃO NACIONAL DE SAÚDE - FUNASA. Manual de saneamento. 3. ed. Brasília, 2007.

GURGEL, Helen C.; BILLA, Michèle; MAZZEGA, Pierre. Água, saúde e territórios: uma breve discussão. Paranoá: cadernos de arquitetura e urbanismo, n. 10, p. 15-24, 2014.

JACOBI, Pedro. Moradores e meio ambiente na cidade de São Paulo. São Paulo: Centro de Estudos de Cultura Contemporânea, 1995.

JACOBSEN, Kathryn H.; WIERSMA, Steven T. Hepatitis A virus seroprevalence by age and world region, 1990 and 2005. Vaccine, v. 28, n. 41, p. 6653-6657, 2010.

LAGUARDIA, Josué et al. Sistema de Informação de Agravos de Notificação em Saúde Sinan: desafios no desenvolvimento de um sistema de informação em saúde. Epidemiol. Serv. Saúde, Brasília , v. 13, n. 3, p. 135-146, set. 2004 . Disponível em: $<$ http://scielo.iec.pa.gov.br/scielo.php?script=sci_arttext\&pid=S167949742004000300002\&ln $\mathrm{g}=\mathrm{pt \& nrm}=\mathrm{iso}>$. Acesso em 24 nov. 2016.

LIBÂNIO, Paulo Augusto Cunha; CHERNICHARO, Carlos Augusto de Lemos; NASCIMENTO, Nilo de Oliveira. A dimensão da qualidade de água: avaliação da relação entre indicadores sociais, de disponibilidade hídrica, de saneamento e de saúde pública. Engenharia Sanitária e Ambiental, v. 10, n. 3, p. 219-228, 2005.

LIMA-COSTA, Maria Fernanda; BARRETO, Sandhi Maria; GIATTI, Luana. Condições de saúde, capacidade funcional, uso de serviços de saúde e gastos com medicamentos da população idosa brasileira: um estudo descritivo baseado na Pesquisa Nacional por Amostra de Domicílios. Cadernos de Saúde Pública, Rio de Janeiro, v. 19, n. 3, p. 735-43, 2003. 
LILIENFELD, A. M.; LILIENFELD, D. Foundation of epidemiology. New York: Oxford University Press, 1980.

HAESBAERT R. O mito da desterritorialização: do "fim dos territórios" à multierritorialidade. Rio de Janeiro: Bertrand Brasil, 2004.

HELLER, L. Saneamento e saúde. Brasília: Organização PanAmericana da Saúde, 1997. MARSHALL, M. Teresa; MARGARITA, Sáez; SALINAS, Judith. Participación en salud: lecciones y desafíos. In: PARTICIPACION en salud: lecciones y desafios. Corsaps, 1991.

MENDES, E. V. Distritos sanitários: processo social de mudanças nas práticas sanitárias para Sistema Único de Saúde. São Paulo: Hucitec; Rio de Janeiro: Abrasco, 1993.

MACMAHON, B.; PUGH, T. F. Case-control studies. In: EPIDEMIOLOGY: principies and methods. Boston: Little, Brown and Company, 1970. p. 241-282.

MAGUIRE, David J. An overview and definition of GIS. Geographical information systems: Principles and applications, v. 1, p. 9-20, 1991.

MENDONÇA, M. J. C.; MOTTA, R. S. Saúde e saneamento no Brasil. Rio de Janeiro: Ipea, 2005. (Texto para Discussão, n. 1.081).

MEDRONHO, Roberto A. et al. Epidemiologia. In: Epidemiologia. São Paulo: Atheneu,2003. p. 493-493.

MONKEN, Maurício; BARCELLOS, Christovam. Vigilância em saúde e território utilizado: possibilidades teóricas e metodológicas $=$ Health surveillance and territory: theoretical and methodological possibilities. Cadernos de Saúde Pública, Rio de Janeiro, v. 21, n. 3, p. 898906, 2005.

MONKEN, Maurício et al. O território na saúde: construindo referências para análises em saúde e ambiente. In: MIRANDA, A. C. et al. Território, ambiente e saúde. Rio de Janeiro: Fiocruz, 2008. p. 23-41.

MORAES, Danielle Serra de Lima; JORDÃO, Berenice Quinzani. Water resources deterioration and its impact on human health. Revista de Saúde Pública, v. 36, n. 3, p. 370374, 2002.

MOTTA, Ronaldo Seroa da. Indicadores ambientais no Brasil: aspectos ecológicos, de eficiência e distributivos. Rio de Janeiro: Ipea, 1996.

GERVÁSIO NETO, Soares Barbosa. Método de classificação semiautomático das unidades básicas de relevo em regiões tropicais. 2015. Tese (Doutorado)-Universidade de Brasília , Brasília, 2015.

NOSSA, Paulo Nuno. Saúde e espaço: abordagem teórico-metodológica em geografia da saúde. Porto: Afrontamento, 2012.

NURMINEN, M., Linkage failures in ecological studies. World Health Statistic Quarterly, 48, p. 78-84, 1995. 
O'CALLAGHAN, John F.; MARK, David M. The extraction of drainage networks from digital elevation data. Computer vision, graphics, and image processing, v. 28, n. 3, p. 323344, 1984.

ORGANIZACIÓN MUNDIAL DE LA SALU - OMS. Criterios Eticos para la Promoción de Medicamentos. Ginebra: OMS, 1988.

PAN AMERICAN HEALTH ORGANIZATION. Enfoques ecossistêmicos em saúde: perspectivas para sua adoção no Brasil e países da América Latina. Washington, D.C.: PAHO, 2009.

PAVIANI, Aldo. Brasília: ideologia e realidade: espaço urbano em questão. In: BRASÍLIA: ideologia e realidade: espaço urbano em questão. Brasília: CNPq Projeto, 1985.

PAVIANI, Aldo. A construção injusta do espaço urbano. In: A conquista da cidade: movimentos populares em Brasília. Brasília: Editora UnB, 1991.

PAVIANI, Aldo. Demandas sociais e ocupação do espaço urbano: o caso de Brasília, DF. Brasília: Editora UnB, 2009. (Cadernos Metrópole, n. 21).

PAVIANI, Aldo; SCHVASBERG, Benny. Brasília, moradia e exclusão. Brasília: Editora UnB, 1996.

PEREIRA, Fausto E. L.; GONÇALVES, Carlos S. Hepatitis A. Revista da Sociedade Brasileira de Medicina Tropical, v. 36, n. 3, p. 387-400, 2003.

PRADO, Tatiana; MIAGOSTOVICH, Marize Pereira. Virologia ambiental e saneamento no Brasil: uma revisão narrativa. Cad. Saúde Pública, Rio de Janeiro , v. 30, n. 7, p. 1367-1378, Julho $2014 \quad$. Disponível em $<$ http://www.scielo.br/scielo.php?script=sci_arttext\&pid=S0102-

311X2014000701367\&lng=en\&nrm=iso>. Acesso em 12 de Novembro de 2017.

OTONI, Priscilla. Relações de poder entre estado, mercado e sociedade no contexto do capitalismo desregulamentado: estudo de caso sobre a indústria de cimento no Distrito Federal. 2014. 172p. Dissertação (Mestrado)-Desenvolvimento Sociedade e Cooperação Internacional. Universidade de Brasília. Brasília, 2014.

POSSAS, C. Padrões epidemiológicos: uma proposta conceitual. In : POSSAS, C. (Org.). Epidemiologia e sociedade: heterogeneidade estrutural e saúde no Brasil. São Paulo: Hucitec, 1989. p. 179-234.

PRÜSS-ÜSTÜN, A. et al. Safer water, better health: costs, benefits and sustainability of interventions to protect and promote health. Genebra: WHO, 2008. 60p.

SECRETARIA DE ESTADO DE SAÚDE DO DISTRITO FEDERAL. Plano Distrital de Saúde: 2016 a 2019. Brasília, 2016. Disponível em: <http://www.saude.df.gov.br/images/ LAI/Planos/PDS_2016-2019_OFICIAL_Parte_II.pdf>. Acesso em 12 maio de 2016. 
RÊGO, Rita de Cássia Franco; BARRETO, Maurício L.; KILLINGER, Cristina Larrea. O que é lixo afinal?: como pensam mulheres residentes na periferia de um grande centro urbano = What is garbage, anyway? : the opinions of women from an outlying neighborhood. Cadernos de Saúde Pública, Rio de Janeiro, v. 18, n. 6, p. 1583-1592, 2002.

SANTOS, Milton. Metamorfoses do espaço habitado. São Paulo: Hucitec, v. 4, 1988.

SANTOS, Damião Carlos Moraes dos et al. Seroepidemiological markers of enterically transmitted viral hepatitis $\mathrm{A}$ and $\mathrm{E}$ in individuals living in a community located in the North Area of Rio de Janeiro, RJ, Brazil. Memórias do Instituto Oswaldo Cruz, v. 97, n. 5, p. 637-640, 2002.

SCHMIDT, Jo; DIKAU, R. Extracting geomorphometric attributes and objects from digital elevation models semantics, methods, future needs. GIS for Earth Surface Systems, p. 153174, 1999.

SILVA, Luiz Jacintho da. O conceito de espaço na epidemiologia das doenças infecciosas. Cadernos de Saúde Pública, Rio de Janeiro, v. 13, n. 4, p. 585-593, 1997.

SILVA, Jorge Xavier da; ZAIDAN, Ricardo Tavares. Geoprocessamento e análise ambiental: aplicações. In: Geoprocessamento e análise ambiental: aplicações. Bertrand Brasil, 2004.

SILVA, Patrícia de Castro et al. Hepatite A no Município do Rio de Janeiro, Brasil: padrão epidemiológico e associação das variáveis sócio-ambientais. vinculando dados do Sinan aos do Censo Demográfico = Hepatitis $\mathrm{A}$ in the city of Rio de Janeiro, Brazil. Cadernos de Saúde Pública, Rio de Janeiro, v. 23, n. 7, p. 1553-1564, 2007.

SMITH A, Reacher M. et al. Outbreaks of waterborne infectious intestinal disease in England and Wales, 1992-2003. Epidemiol Infect, 134, p. 1141-1149, 2006.

SOARES, Helen de Oliveira. Soroprevalência da infecção pelo vírus da hepatite A em catadores de materiais recicláveis em Goiânia, Goiás. 2013. 72 p. Dissertação (Mestrado)Universidade Federal de Goiás, Faculdade de Enfermagem. Goiânia: Universidade Federal de Goiás, 2013.

TAUIL, Márcia de Cantuária et al. Surto de Hepatite A em área urbana de Luziânia, Estado de Goiás, 2009. Revista da Sociedade Brasileira de Medicina Tropical, v. 43, n. 6, p. 740$742,2010$.

TRAVASSOS, Claudia; MARTINS, Mônica. Uma revisão sobre os conceitos de acesso e utilização de serviços de saúde A review of concepts in health services access and utilization. Cadernos de Saúde Pública, Rio de Janeiro, v. 20, n. Sup 2, p. S190-S198, 2004.

TUCCI, Carlos E. M. Águas urbanas. Estudos avançados, v. 22, n. 63, p. 97-112, 2008.

TUCCI, Carlos E. M. et al. Gestão da água no Brasil. Brasília: Unesco, 2001.

TUNDISI, José Galizia. Novas perspectivas para a gestão de recursos hídricos. Revista USP, São Paulo, n. 70, p. 24-35, 2006. 
TUROLLA, Frederico A. Política de saneamento básico: avanços recentes e opções futuras de políticas públicas. Brasília: IPEA, 2002.

UNGLERT, C. V. S. Territorialização em sistemas de saúde. In: MENDES, E. V. (Org.). Distrito sanitário. São Paulo: Hucitec; Rio de Janeiro: Abrasco, 1995. p. 221-235.

VASCONCELOS, Adirson. As cidades satélites de Brasília. Brasília: Thesaurus, 1988.

VILLAR, Livia Melo; DE PAULA, Vanessa Salete; GASPAR, Ana Maria Coimbra. Seasonal variation of hepatitis A virus infection in the city of Rio de Janeiro, Brazil. Revista do Instituto de Medicina Tropical de São Paulo, v. 44, n. 5, p. 289-292, 2002.

WALDMAN, Eliseu Alves; DA COSTA ROSA, Tereza Etsuko. Vigilância em saúde pública. São Paulo: Universidade de São Paulo. Faculdade de Saude Publica, 1998.

WERNECK, Guilherme L.; STRUCHINER, Claudio J. Estudos de agregados de doença no espaço-tempo: conceitos, técnicas e desafios Studies on space-time disease clusters: concepts, techniques, and challenges. Cadernos de Saúde Pública, Rio de Janeiro, v. 13, n. 4, p. 611624, 1997.

WORLD HEALTH ORGANIZATION WHO. Position paper on Hepatitis A vaccines-June 2012. Weekly Epidemiol Rec, v. 87, n. 28-9, p. 261-76, 2012.

ZHANG, Weihua; MONTGOMERY, David R. Digital elevation model grid size, landscape representation, and hydrologic simulations. Water resources research, v. 30, n. 4, p. 1019$1028,1994$. 